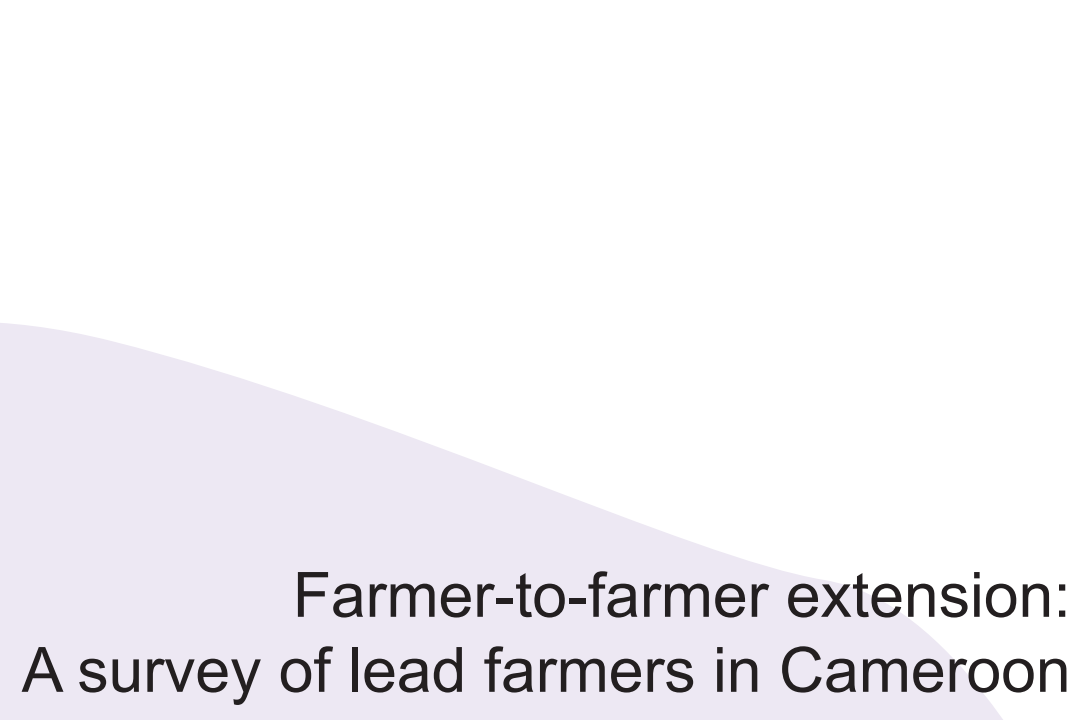




\section{Farmer-to-farmer extension: A survey of lead farmers in Cameroon}

Sygnola Antoine Matsop Tsafack, Ann Degrande, Steven Franzel, Brent Simpson

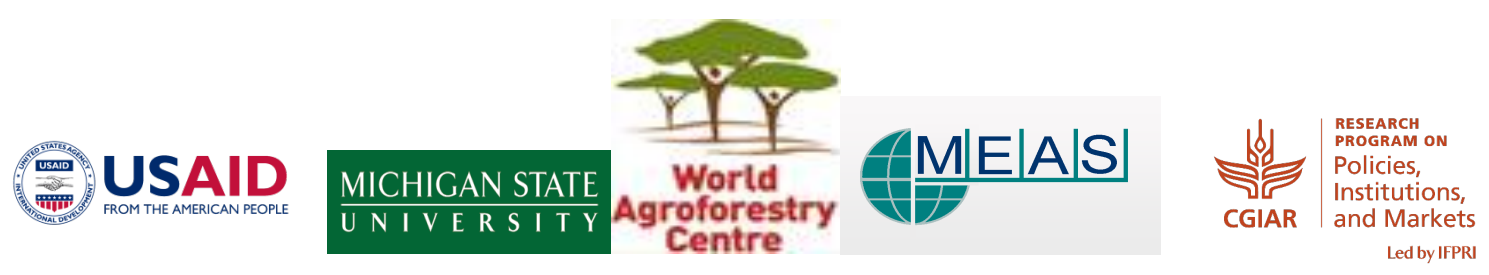


Correct citation: Tsafack SAM, Degrande A, Franzel S, Simpson B. 2015. Farmer-to-farmer extension: a survey of lead farmers in Cameroon. ICRAF Working Paper No. 195. Nairobi, World Agroforestry Centre. DOI: http://dx.doi.org/10.5716/WP15009.PDF

Titles in the Working Paper Series aim to disseminate interim results on agroforestry research and practices and stimulate feedback from the scientific community. Other publication series from the World Agroforestry Centre include: Technical Manuals, Occasional Papers and the Trees for Change Series.

Published by the World Agroforestry Centre

United Nations Avenue

PO Box 30677, GPO 00100

Nairobi, Kenya

Tel: +254(0)20 722 4000, via USA +1 6508336645

Fax: +254(0)20 722 4001, via USA +1 6508336646

Email: worldagroforestry@cgiar.org

Website: www.worldagroforestry.org

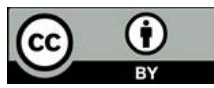

(C) World Agroforestry Centre, Brent Simpson, and MEAS Project. This work is licensed under a Creative Commons Attribution 3.0 Unported License.

This Discussion Paper was produced as part of the United States Agency for International Development (USAID) project "Modernizing Extension and Advisory Services" (MEAS, www.measextension.org). Leader with Associates Cooperative Agreement No. AID-OAA-L-10-00003.

The report was made possible by the generous support of the American people through USAID. The contents are the responsibility of the authors and do not necessarily reflect the views of USAID or the United States government.

Users are free to share - to copy, distribute and transmit the work and to remix — to adapt the work, under the following condition: Attribution - users must attribute the work to the authors, but not in any way that suggests that the authors endorse the user or the user's use of the work.

The views expressed in this publication are those of the authors and not necessarily those of the World Agroforestry Centre. 


\section{THE AUTHORS}

Sygnola Antoine Matsop Tsafack and Ann Degrande work for the World Agroforestry Centre in Yaounde, Cameroon. Steven Franzel works for the World Agroforestry Centre in Nairobi, Kenya. Brent Simpson works for Michigan State University, East Lansing, Michigan, USA.

\section{ACKNOWLEDGMENTS}

Funding support for this study was provided by the US Agency for International Development (USAID) project "Modernizing Extension and Advisory Services" (MEAS, www.measextension.org) and the CGIAR Research Program on Policies, Institutions and Markets. This work was undertaken as part of the CGIAR Research Program on Policies, Institutions and Markets (PIM) led by the International Food Policy Research Institute (IFPRI). The authors express their sincere gratitude to all organizations and farmers who agreed to take part, especially lead farmers who responded during interviews. This publication has not gone through IFPRI's standard peer-review procedure. The opinions expressed here belong to the authors and do not necessarily reflect those of PIM, IFPRI, CGIAR, MEAS, USAID or the United States government. 


\section{CONTENT}

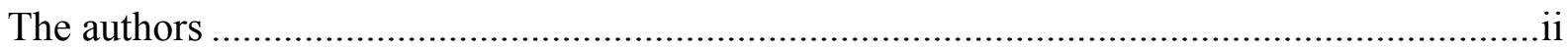

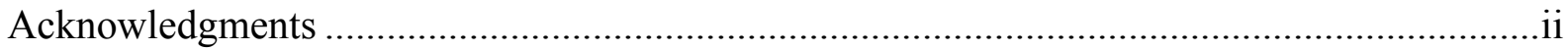

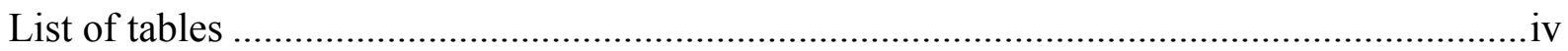

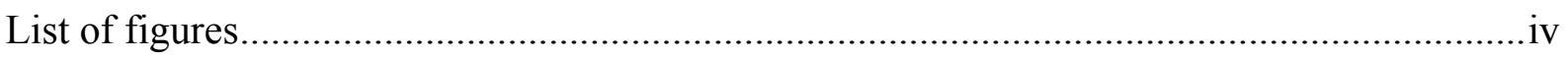

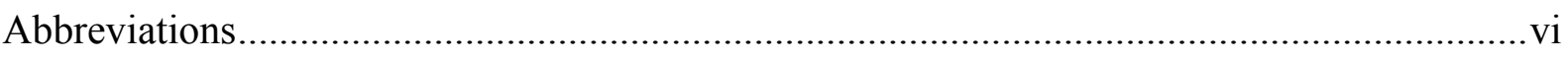

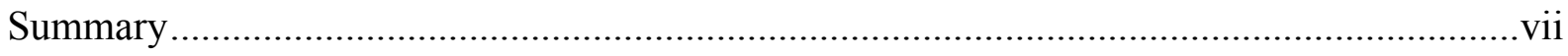

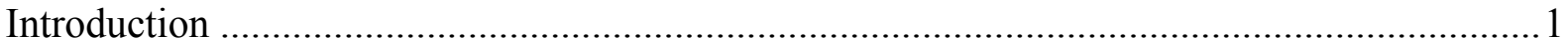

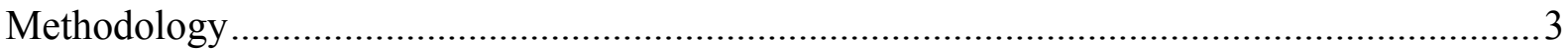

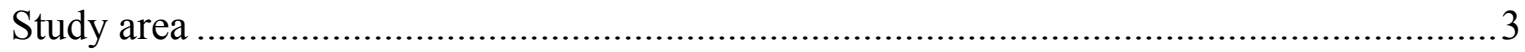

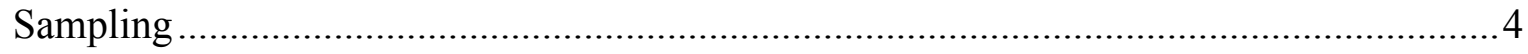

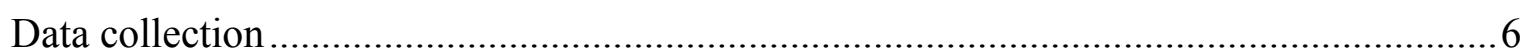

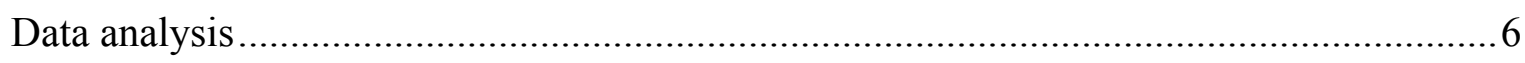

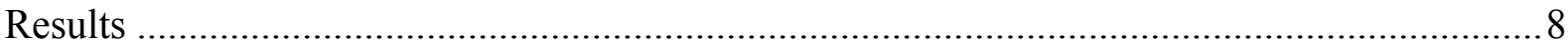

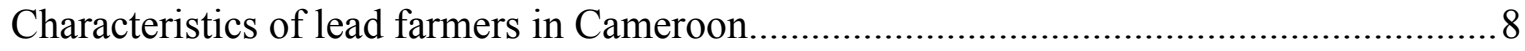

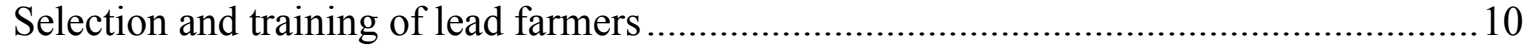

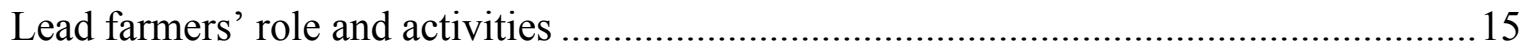

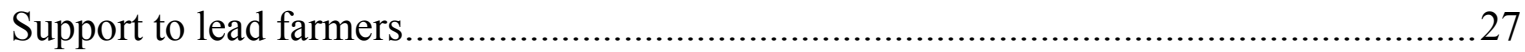

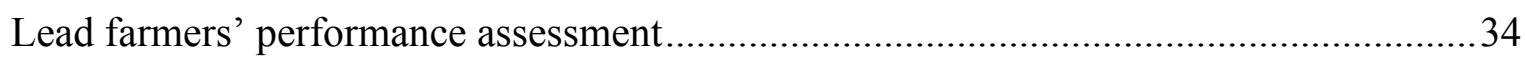

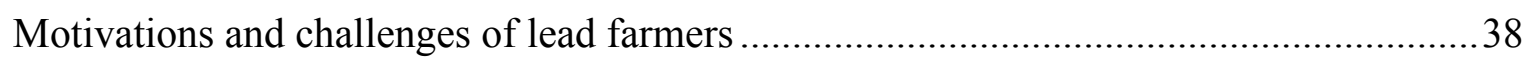

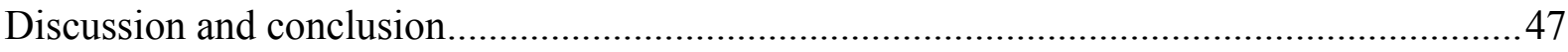

Who are lead farmers, what do they do and how are they supported? ..............................47

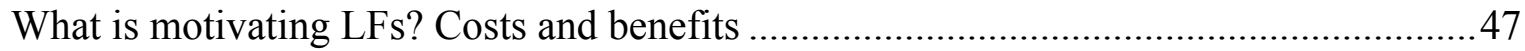

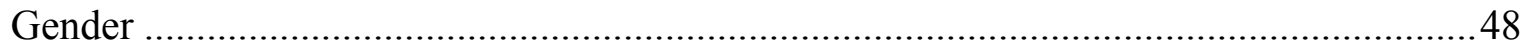

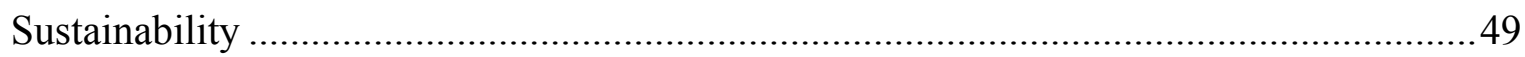

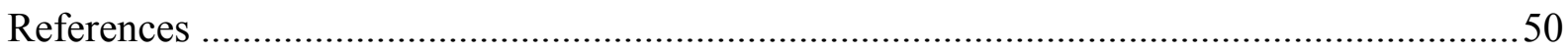




\section{LIST OF TABLES}

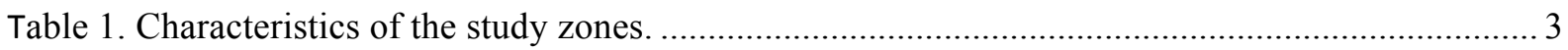

Table 2. Number of lead farmers selected per organization. ........................................................ 5

Table 3. Distribution of lead farmers interviewed in Cameroon. ............................................................ 5

Table 4. Educational levels of lead farmers in Cameroon. .................................................................. 8

Table 5. Year that lead farmers started their function in Cameroon................................................... 10

Table 6. Subjects taught to lead farmers during initial and additional training sessions....................... 13

Table 7. Variation between topics taught by LFs to their peers and topics that they were trained on. . 16

Table 8. Competence ratings declared by LFs on the topics they trained farmers on........................... 18

Table 9. Number of groups a lead farmer worked with......................................................................... 20

Table 10. Number of groups trained by lead farmers based on the number of groups they belonged to.

Table 11. Number of groups trained by a lead farmer based on educational level............................... 21

Table 12. Correlation of some factors with number of groups trained by lead farmers........................ 22

Table 13. Frequencies of follow-up visits with trainees by lead farmers. ............................................ 23

Table 14. Payment of transportation and communication costs of LFs to interact with farmers. ......... 26

Table 15. Frequency of meetings of lead farmers with field staff members. ....................................... 27

Table 16. Demonstration materials received by lead farmers to train farmers..................................... 30

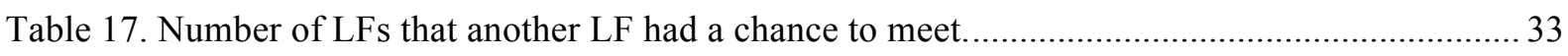

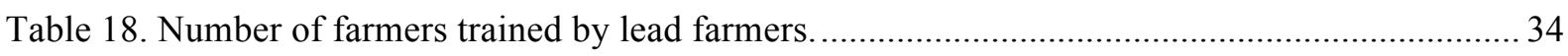

Table 19. Most successful and least successful topics taught by lead farmers.................................... 35

Table 20. Farmers' ranking of their motivations to become and remain LFs........................................ 39

\section{LIST OF FIGURES}

Figure 1. Location of LFs interviewed during the F2F survey in Cameroon. ....................................... 6

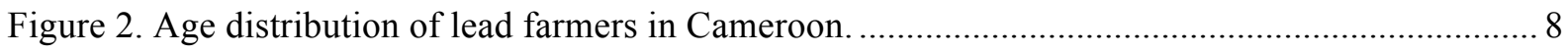

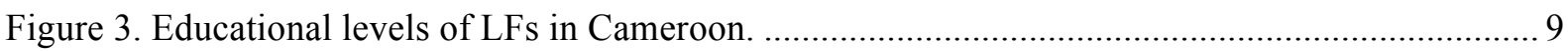

Figure 4. Terms used to refer to lead farmers in Cameroon (according to LFs). .................................. 9

Figure 5. Criteria mentioned by lead farmers in Cameroon as priority for their selection..................... 11

Figure 6. Technical topics dealt with during LFs' initial and additional trainings............................... 12

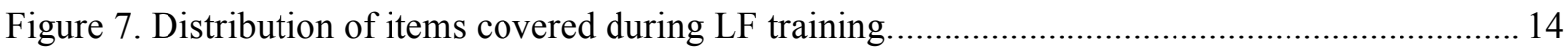

Figure 8. Timing of additional trainings of lead farmers in Cameroon............................................... 14

Figure 9. Activities carried out by lead farmers in Cameroon............................................................... 16 
Figure 10. Competence ratings of lead farmers on topics they trained farmers on.

Figure 11. Frequencies of methods used for identifying training needs of farmers by LFs.................20

Figure 12. Distribution of the sizes of groups that lead farmers worked with...................................... 22

Figure 13. Places where lead farmers trained farmers........................................................................ 24

Figure 14. Means of transportation used by lead farmers to meet trainees. ............................................ 24

Figure 15. Types of communication used by LFs to interact with farmers ......................................... 25

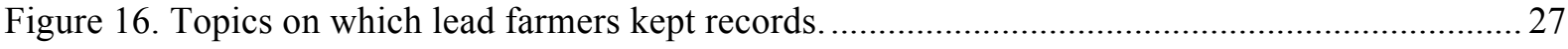

Figure 17. Payment for communication methods used by lead farmers to interact with field staff

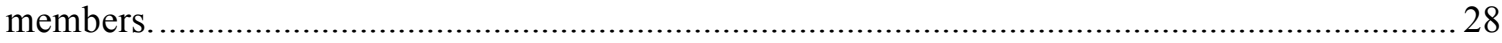

Figure 18. Training and support materials received or kept by lead farmers. ...................................... 29

Figure 19. Types of compensation received by lead farmers. ................................................................. 30

Figure 20. Actions that lead farmers took in case of technical question asked by trainees................... 31

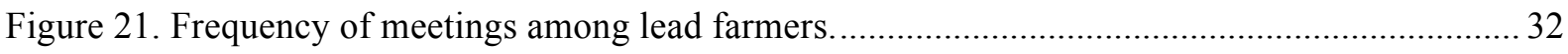

Figure 22. Main topics discussed by lead farmers during their meetings........................................... 33

Figure 23. Types of incentives given by organizations to LFs who successfully innovated.................37

Figure 24. Motivations mentioned by LFs to become LFs.................................................................. 38

Figure 25. Main benefits of the farmer-to-farmer approach observed by lead farmers........................ 40

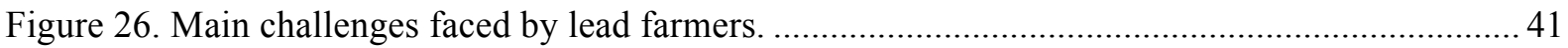

Figure 27. Costs incurred by lead farmers in training farmers over the previous 12 months............... 42

Figure 28. Main domains of expenditures incurred by lead farmers during the previous 12 months... 43

Figure 29. Suggestions by LFs to make farmer-to-farmer approach benefit more farmers................... 44

Figure 30. Reasons for lead farmers to continue to serve if organization leaves or projects end.......... 45

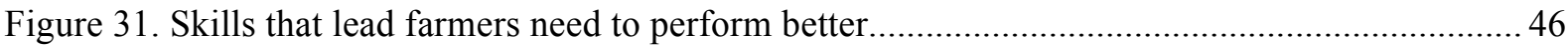




\section{ABBREVIATIONS}

ADD

AJESH

ANCO

BERUDA

CIEFAD

CIMAR

CIPCRE

ERUDEF

F2F

FO

FS

GEW

Gic PRO AGRO

HPI

LF

MIFACIG

NOWEFOR

NPO/NGO

PLANOPAC

RARC

SAILD

SIRDEP

SNV

SOCADYC

UCOPADCAM-

BINUM
: Alternative Durable pour le Développement

: Ajemalibu Self Help

: Apiculture and Nature Conservation

: Belo Rural Development Association

: Centre Intégré d'Expérimentation et de Formation en Agriculture Durable

: Centre d'Insertion aux Métiers Agricoles et Ruraux

: Cercle International pour la Promotion de la Création

: Environmental and Rural Development Foundation

: Farmer-to-Farmer

\section{Farmer Organization}

: Field Staff

: Government Extension Worker

: Gic des Promoteurs d'Agroforesterie de l'Ouest

: Heifer Project International

: Lead Farmer

: Twantoh Mixed Farming Common Initiative Group

: North West Farmers' Organization

: Non-Profit Organization/Non-Governmental Organization

: Plate-forme Nationale des Organisations Agro-sylvo-pastorale du Cameroun

: Riba Agroforestry Resource Centre

: Service d'Appui aux Initiatives Locales de Développement

: Society for Initiatives in Rural Development and Environmental Protection

: Organisation Néerlandaise de Développement

: Société Coopérative des Agriculteurs Dynamiques du Centre

: Union des Sociétés Coopérative BINUM des Producteurs Agro-pastoraux du Cameroun 


\section{SUMMARY}

This study examines how the farmer-to-farmer (F2F) extension approach is implemented by farmer trainers in Cameroon. Those farmers selected to lead F2F extension are often known by different names but in this study, we use the term "lead farmer" (LF) as a generic term even though different names sometimes imply different roles. A questionnaire was used to collect data from 160 randomly selected LFs in six regions in Cameroon in 2013. The study describes the activities of LFs and the support they receive, assesses their technical competence and identifies factors that motivate them, as well as the challenges they face in implementing the F2F approach.

In Cameroon, about half of the LFs (52 percent) were between 41 and 55 years old. Most LFs (81 percent) were married, and more than half had education levels above primary school. A majority of LFs started serving in their roles between 2005 and 2009. After their selection, through their group/community or from the extension field staff, LFs received an initial residential training of 6.8 days on average (median $=$ three days). They also received additional training during their service.

The major functions of LFs were to provide other farmers with technical advice, supervise their activities, and mobilize their community for awareness or training sessions. Although LFs declared that their competencies in the techniques that they taught others were often insufficient, they rated their competence level on the innovations that they disseminated at 3.8 on a scale of 1 to 5 .

Most (93 percent) topics taught by LFs were supported with practical exercises, and 91 percent of techniques were actually applied by trainees on their farms. Training needs were generally set by organizations who conducted their own training needs assessments. Lead farmers had some involvement in this process as training needs were identified through farmers' requests. On average, a lead farmer trained five groups of 26.3 farmers each and 37 additional farmers outside of organized groups (median of total number of trainees per LF = 65). The most common places where LFs conducted training were in group/community halls, at trainees' houses/farms, or at the LF's house/farm. Transportation and communication expenses were mainly paid by LFs themselves.

Half of the LFs received training and demonstration materials from the organizations supporting their efforts. Almost all LFs (95 percent) reported being able to increase their income from being a LF and 94.4 percent believed that their trainees were also able to earn more income as a result of the new farming techniques that they learned. To improve upon their activities, 57 percent of LFs collaborated with government extension agents. In addition, some LFs met among themselves, mostly once a month.

Since they started their work as LFs, each one had trained on average 231 farmers (median = 100). In the year before the interview, LFs had trained on average 58 farmers (median =17). There was no significant difference between male and female LFs concerning the numbers of farmers trained. Female LFs trained more women compared to their male colleagues (74 
percent against 41 percent of trainees being women, respectively). Overall, 53.7 percent of farmers trained in the past year were female.

Almost all LFs (98.1 percent) mentioned at least one topic that they successfully passed on to their trainees. However, 86.9 percent of LFs also cited topics for which training was less successful.

The number of female and male LFs trained in the past year were not significantly different. Female LFs seemed to work more with individual farmers than their male counterparts. When working with groups, they mostly associated with one group only while men LFs worked with five groups on average. Female LFs also tended to train more farmers in their own houses/farms than men LFs, who trained more in community halls and in the trainees' houses/farms.

Altruism, increasing one's income and getting early access to new technologies were the main motivations for LFs to become or remain LFs. A majority (60 percent) of LFs found the F2F approach to be very useful for developing local capacity, increasing technology adoption and increasing access to extension. Identified challenges were budget limitations, insufficient transportation and lack of communication support.

Almost all LFs (94 percent) reported their intention to continue to train fellow farmers even after organizations working with them leave or the projects end. To improve the F2F approach and to make it beneficial to more farmers, 81 percent of LFs mentioned issues related to their motivation, such as "improving their conditions" and the desire to be supported in becoming real "model farmers". Interview responses also indicate that there is a need to train more LFs and/or refresh their knowledge, especially in communication skills and improved agricultural practices, as well as to build awareness of authorities and projects/organizations of the importance of the F2F approach and to encourage more youth to join groups served by LFs.

Key words: Rural advisory services, gender, voluntarism, agricultural extension 


\section{INTRODUCTION}

In most developing countries, smallholder farmers have insufficient opportunities to learn about new technologies and improved agricultural methods (Gale et al., 2013). The main challenge facing agricultural extension efforts, therefore, is how to develop low-cost, sustainable approaches to providing information and services. There is also need to identify ways of going beyond simple message delivery to finding ways of making farmers the principal agents of change in their own communities (Lukuyu et al., 2012).

Financial and staffing constraints render most public-sector extension services unable to provide the majority of small-scale farmers with adequate extension services. In response, new approaches have evolved to fill the gap. One approach that is being broadly applied is the farmer-to-farmer (F2F) approach to extension. The F2F approach responds to farmers' needs for information on new practices, inputs and technologies through lead farmers, who share their knowledge and experience with others, and host demonstrations and experiments on their farms (Kiptot and Franzel, 2012 and Hird-Younger and Simpson, 2013). Those farmers selected to lead F2F extension are often known by different names but in this study, we use the term "lead farmer" as a generic term even though different names sometimes imply different roles. Use of the F2F approach aims to reach large numbers of farmers at low cost through the multiplier effect of F2F communication.

According to Kiptot and Franzel (2014), F2F extension is a viable method of technology dissemination based on the conviction that farmers disseminate innovations among peers more efficiently than external extension agents. Likewise, Bentley et al. (2013) and HirdYounger and Simpson (2013) have suggested that farmers are more receptive to making changes/testing innovations when they are proposed by familiar and trusted sources. Others have proposed that the approach can enable farmers to make better decisions, provide feedback to researchers and policymakers (Kiptot et al., 2006), and even result in radical changes in farmers' mental maps of their role in the process of technology generation and diffusion (Braun and Hocde, 2000).

The F2F approach seems particularly relevant for disseminating innovations to farmers (Lukuyu et al., 2012) and improving their livelihoods, yet few studies have been carried out on this method of extension and advisory service, and none have examined the use of the approach across organizations and between countries. The present study is part of a multicountry assessment (Cameroon, Kenya and Malawi) undertaken to examine the various forms that the F2F approach has taken, its strengths and weaknesses, and prospects for offering a viable alternative to traditional approaches to agricultural extension.

The overall objective of the present study is to understand how the F2F approach is being implemented in Cameroon in order to appreciate the dissemination capacity of LFs and identify their motivations and the constraints of the F2F approach. Specifically, the study attempts to:

- Characterize lead farmers (LFs).

- Describe the content of LFs' activities and their support. 
- Assess the competency levels of lead farmers in fulfilling their roles.

- Identify factors that motivate LFs and challenges they face in implementing F2F extension in Cameroon.

The information will be useful for extension service managers and policymakers interested in improving methods of promoting the diffusion of information and uptake of improved agricultural practices. 


\section{METHODOLOGY}

\section{Study area}

The study was carried out in three agroecological zones of the country - the western highlands, the forest zone with unimodal rainfall and the forest zone with bimodal rainfall. Characteristics of the study sites are summarized in Table 1.

Table 1. Characteristics of the study zones.

\begin{tabular}{|c|c|c|c|}
\hline \multirow[b]{2}{*}{ Characteristics } & \multicolumn{3}{|c|}{ Agroecological zones } \\
\hline & $\begin{array}{l}\text { Western Highlands « Hauts } \\
\text { Plateaux » }\end{array}$ & $\begin{array}{l}\text { Forest, unimodal } \\
\text { rainfall }\end{array}$ & $\begin{array}{l}\text { Forest, bimodal } \\
\text { rainfall }\end{array}$ \\
\hline Location & $\begin{array}{l}\text { From Nde division to North- } \\
\text { West region and part of } \\
\text { South-West }\end{array}$ & $\begin{array}{l}\text { From Littoral to South- } \\
\text { West, and coastal area of } \\
\text { South region }\end{array}$ & $\begin{array}{l}\text { Centre, South and East } \\
\text { regions }\end{array}$ \\
\hline Surface & $31192 \mathrm{~km}^{2}$ & $45658 \mathrm{~km}^{2}$ & $165770 \mathrm{~km}^{2}$ \\
\hline Coordinates & $\begin{array}{l}5^{\circ} 00-7^{\circ} 00 \mathrm{~N} \\
9^{\mathrm{o}} 50-11^{\mathrm{o}} 15 \mathrm{E}\end{array}$ & $\begin{array}{l}4^{\circ} 00-6^{\circ} 30 \mathrm{~N} \\
8^{\mathrm{o}} 30-10^{\circ} 00 \mathrm{E}\end{array}$ & $\begin{array}{l}2^{\circ} 00-4^{\circ} 00 \mathrm{~N} \\
10^{\circ} 31-16^{\circ} 12 \mathrm{E}\end{array}$ \\
\hline $\begin{array}{l}\text { Relief and } \\
\text { vegetation }\end{array}$ & $\begin{array}{l}\text { Mountainous areas } \\
\text { characterized by savannah } \\
\text { vegetation; plateaus and } \\
\text { valleys crossed by gallery } \\
\text { forests. }\end{array}$ & $\begin{array}{l}\text { Mountains with steep } \\
\text { slopes and valleys. In the } \\
\text { west, dominated by a } \\
\text { volcanic chain (Mts. } \\
\text { Cameroon, Manengouba, } \\
\text { Nlonako and Koupe). }\end{array}$ & $\begin{array}{l}\text { Mid-altitude plateau } \\
(300-600 \mathrm{~m} \text { above sea } \\
\text { level) }\end{array}$ \\
\hline Soils & $\begin{array}{l}\text { Young soils on slopes } \\
\text { (Incepticols), highly } \\
\text { weathered soils (Oxisols), } \\
\text { soils with horizon B (Alfisols } \\
\text { and Ultisols) and plateaus } \\
\text { with rich volcanic soils. } \\
\text { Organic material more than } \\
1.5 \text { percent. Moderate to high } \\
\text { N level, high Mg level and } \\
\text { very low K. }\end{array}$ & $\begin{array}{l}\text { Rich and deep Andosols } \\
\text { in the north. In the south, } \\
\text { lowlands with sandy } \\
\text { Ferralitic soils. }\end{array}$ & $\begin{array}{l}\text { Mainly Ferralitic, acid, } \\
\text { clay soils that are red or } \\
\text { yellow according to the } \\
\text { season. Low nutrient- } \\
\text { retention capacity. } \\
\text { Rapid degradation of } \\
\text { nutrients after } \\
\text { cultivation. }\end{array}$ \\
\hline Climate & $\begin{array}{l}\text { Two seasons: dry season } \\
\text { (mid-November to mid- } \\
\text { March) and rainy season } \\
\text { (mid-March to mid- } \\
\text { November). Rainfall between } \\
1500 \text { and } 2600 \mathrm{~mm} \text {. } \\
\text { Relatively low temperatures } \\
\left(20^{\circ} \mathrm{C} \text { on average). }\right.\end{array}$ & $\begin{array}{l}\text { Equatorial oceanic: hot } \\
\text { and humid with two } \\
\text { seasons: rainy season } \\
\text { (mid-March to mid- } \\
\text { November) and a dry } \\
\text { season with high } \\
\text { humidity. Rainfall of } \\
4000 \mathrm{~mm} \text { per year, with } \\
\text { records of } 11,000 \mathrm{~mm} \text { on } \\
\text { the slopes of Mt } \\
\text { Cameroon. } \\
\text { Stable temperatures }\left(25^{\circ} \mathrm{C}\right.\end{array}$ & $\begin{array}{l}\text { Subequatorial Congo- } \\
\text { Guinea type, with four } \\
\text { seasons: short rainy } \\
\text { season (March-June), } \\
\text { short dry spell (July- } \\
\text { August), long rainy } \\
\text { season (September- } \\
\text { November), long dry } \\
\text { season (December- } \\
\text { February). Rainfall } \\
\text { between } 1500 \text { and } 2000 \\
\text { mm over } 10 \text { months. }\end{array}$ \\
\hline
\end{tabular}




\begin{tabular}{|c|c|c|c|}
\hline \multirow[b]{2}{*}{ Characteristics } & \multicolumn{3}{|c|}{ Agroecological zones } \\
\hline & $\begin{array}{l}\text { Western Highlands « Hauts } \\
\text { Plateaux » }\end{array}$ & $\begin{array}{l}\text { Forest, unimodal } \\
\text { rainfall }\end{array}$ & $\begin{array}{l}\text { Forest, bimodal } \\
\text { rainfall }\end{array}$ \\
\hline & & on average). & $\begin{array}{l}\text { Rather constant } \\
\text { temperatures }\left(23^{\circ} \text { - }\right. \\
\left.27^{\circ} \mathrm{C}\right) \text {. }\end{array}$ \\
\hline $\begin{array}{l}\text { Agroecological } \\
\text { potential }\end{array}$ & $\begin{array}{l}\text { Fertile soils suitable to } \\
\text { agricultural activities, } \\
\text { especially food crops (maize, } \\
\text { beans, potato, gardening), } \\
\text { horticulture and Arabica } \\
\text { coffee, often in association, } \\
\text { and two cropping cycles per } \\
\text { year. Small livestock } \\
\text { husbandry. }\end{array}$ & $\begin{array}{l}\text { Northern part has big } \\
\text { industrial plantations of } \\
\text { banana, rubber, tea and } \\
\text { oil palm. Also food crops } \\
\text { (tubers, maize, cowpea, } \\
\text { ginger, pepper), cocoa, } \\
\text { coffee and horticulture. } \\
\text { Small livestock } \\
\text { husbandry and } \\
\text { aquaculture. }\end{array}$ & $\begin{array}{l}\text { Soils suitable for } \\
\text { cultivation of banana, } \\
\text { plantain, cocoyam, } \\
\text { cassava, sweet potato, } \\
\text { yam, maize, groundnut, } \\
\text { pineapple, cocoa, oil } \\
\text { palm, rubber, vegetables } \\
\text { and robusta coffee. } \\
\text { Small livestock } \\
\text { husbandry and } \\
\text { aquaculture. }\end{array}$ \\
\hline $\begin{array}{l}\text { Socioeconomic } \\
\text { characteristics }\end{array}$ & $\begin{array}{l}80 \text { percent of population is } \\
\text { involved in agriculture. } \\
\text { Three main agricultural } \\
\text { areas: Bamoun land } \\
\text { (moderate population } \\
\text { density, vast spaces for } \\
\text { livestock), Bamilike land } \\
\text { (high population density, } \\
\text { multistrata agricultural } \\
\text { systems), grassfields in } \\
\text { North-West. Land is mostly } \\
\text { inherited, and agriculture on } \\
\text { average is small-scale (1.3 ha } \\
\text { per household). }\end{array}$ & $\begin{array}{l}\text { Considered the agro- } \\
\text { industrial hub of } \\
\text { Cameroon. Average } \\
\text { population density: } 176 \\
\text { inhabitants per km². } \\
\text { About } 40 \text { percent are } \\
\text { immigrants from other } \\
\text { parts of the country and } \\
\text { abroad. }\end{array}$ & $\begin{array}{l}\text { Low population density, } \\
\text { apart from areas around } \\
\text { Yaoundé and in the } \\
\text { Lékié division. Land is } \\
\text { mostly inherited, and } \\
\text { agriculture is small- } \\
\text { scale, characterized by } \\
\text { high rural exodus. } \\
\text { Shifting cultivation is } \\
\text { still the dominant } \\
\text { agricultural practice. }\end{array}$ \\
\hline
\end{tabular}

Source: MINADER, 2009, and Degrande et al., 2014.

\section{Sampling}

A stratified sampling technique was used to select LFs. In a companion study on F2F extension in Cameroon (Tsafack et al., 2014), 25 organizations using this approach were interviewed in seven regions (South, East, Centre, Littoral, West, North-West and SouthWest), covering three agroecological zones (western highlands, bimodal and monomodal forest rainfall zones). Among the seven regions, the South region was not considered for this study because the only organization using the F2F approach extension approach in this region could not supply a list of its LFs. In the six remaining regions, all but one organization, in the South-West region, provided a list of their lead LFs. The lists comprised 360 lead farmers (about one-third women) and were ranked according to their respective locations (division, subdivision and village) and by gender. The divisions with large numbers of LFs were then 
retained for this study. This was done to optimize available resources by reducing time and transport costs for interviewing the lead farmers. A total of $176 \mathrm{LFs}$ were randomly selected from the retained lists (Table 2), with a proportion of one-third female LFs. The selected LFs worked for 20 organizations.

Table 2. Number of lead farmers selected per organization.

\begin{tabular}{|l|c|l|c|l|c|}
\hline Organization & $\begin{array}{l}\text { Number of } \\
\text { LFs selected }\end{array}$ & Organization & $\begin{array}{l}\text { Number of } \\
\text { LFs selected }\end{array}$ & Organization & $\begin{array}{l}\text { Number of } \\
\text { LFs selected }\end{array}$ \\
\hline ADD & 13 & ERUDEF & 8 & RARC & 9 \\
\hline AJESH & 4 & Gic PRO AGRO & 7 & SAILD & 3 \\
\hline ANCO & 8 & $\begin{array}{l}\text { Heifer Project } \\
\text { International }\end{array}$ & 6 & SIRDEP & 12 \\
\hline CIEFAD & 12 & MIFACIG & 25 & SVN & 2 \\
\hline BERUDA & 15 & NOWEFOR & 7 & SOCADYC & 5 \\
\hline CIMAR & 5 & Planet Survey & 11 & $\begin{array}{l}\text { UCOPADCAM } \\
\text { BINUM }\end{array}$ & 6 \\
\hline CIPCRE & 3 & PLANOPAC Ouest & 15 & & \\
\hline
\end{tabular}

The proportion of LFs interviewed in South-West region was lower (13 percent) than in the other regions because of the difficulty of making appointments with LFs by phone to set up the interviews and the general remoteness of the villages. During the survey, some of the targeted LFs were not available and were replaced by other LFs from the list. In the end, 160 LFs were interviewed. Table 3 presents the distribution of interviewed LFs per region. Figure 1 shows locations where lead farmers were interviewed.

Table 3. Distribution of lead farmers interviewed in Cameroon.

\begin{tabular}{|c|c|c|c|c|c|c|c|}
\hline \multirow[t]{2}{*}{ Region } & \multirow{2}{*}{$\begin{array}{l}\text { Number } \\
\text { of LFs } \\
\text { listed }\end{array}$} & \multirow{2}{*}{$\begin{array}{c}\text { Number of } \\
\text { LFs } \\
\text { interviewed }\end{array}$} & \multirow{2}{*}{$\begin{array}{c}\text { \% of LFs } \\
\text { interviewed }\end{array}$} & \multicolumn{4}{|c|}{ Women LFs } \\
\hline & & & & $\begin{array}{c}\text { Number } \\
\text { listed }\end{array}$ & \% listed & Region & $\begin{array}{c}\text { Number } \\
\text { of LFs } \\
\text { listed }\end{array}$ \\
\hline Centre & 20 & 13 & 65 & 3 & 15 & 2 & 15 \\
\hline East & 21 & 17 & 81 & 9 & 43 & 9 & 53 \\
\hline Littoral & 11 & 5 & 45 & 0 & 0 & 0 & 0 \\
\hline North-West & 194 & 76 & 39 & 74 & 38 & 34 & 45 \\
\hline South-West & 39 & 5 & 13 & 3 & 8 & 1 & 20 \\
\hline West & 75 & 44 & 59 & 19 & 25 & 15 & 34 \\
\hline Total & 360 & 160 & 44 & 108 & 30 & 61 & 38 \\
\hline
\end{tabular}




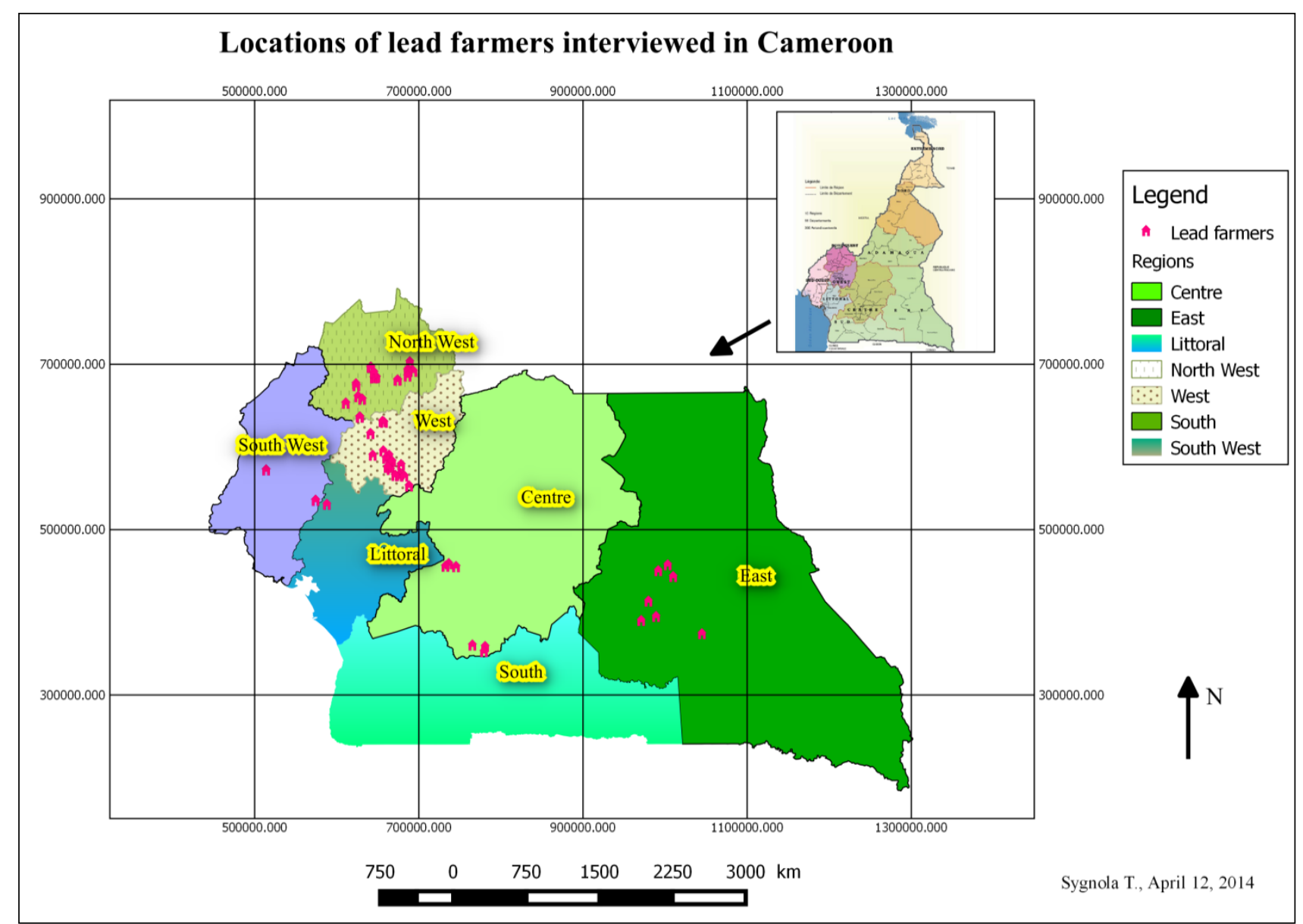

Figure 1. Location of LFs interviewed during the F2F survey in Cameroon.

\section{Data collection}

A semi-structured questionnaire was used to interview LFs. The main topics covered in the survey were general household characteristics of the respondents, criteria used by organizations in selecting LFs, experience as LFs, their dissemination activities, performance, support received, personal motivations for serving as a LF, benefits and challenges of filling the function and their perspectives on the LF approach. Data were collected from the end of August to the end of September 2013. The three enumerators involved in the survey were bilingual, and interviews were done in French or English according to the language spoken by the LF. The interview was completed in two hours on average.

\section{Data analysis}

The data collected were analyzed using descriptive statistics in Excel and SPSS 17.0. Values related to average, sum, minimum and maximum were calculated. In addition, because we wanted to find out whether there were differences between genders for some variables, a comparison was made between responses from female and male LFs. Using the p-value and the significance level $\alpha$ (that is, 0.05), we indicate a significant difference when $\mathrm{P}(\mathrm{t})<\alpha$. When $\alpha$ was greater than 0.05 but less than 0.10 , the difference was labelled as marginally 
significant. We also conducted analyses of variance (ANOVA) and correlations among some variables. For ANOVAs, the model was significant if the p-value of the ANOVA was less than $\alpha(0.05)$. In addition, two variables were significantly correlated when $\mathrm{P}(\mathrm{t})<\alpha$ (Rakotomalala, 2012). 


\section{RESULTS}

\section{Characteristics of lead farmers in Cameroon}

All lead farmers in Cameroon were members of farmer groups in their locality. However, two individuals interviewed decided, after their training as LFs, to disseminate innovations as freelance farmer trainers. The majority ( 83 percent) of LFs were members of the executive boards in their groups (i.e., chair, vice president, secretary, etc.). Around half (48.4 percent) of the LFs belonged to one farmer group; 31 percent and 12 percent were affiliated with two and three groups, respectively. Women made up 38 percent of the lead farmers. About half (52 percent) of LFs were between 41 and 55 years old, 12.5 percent were above 60 years and the youngest was 21 years old (Figure 2).

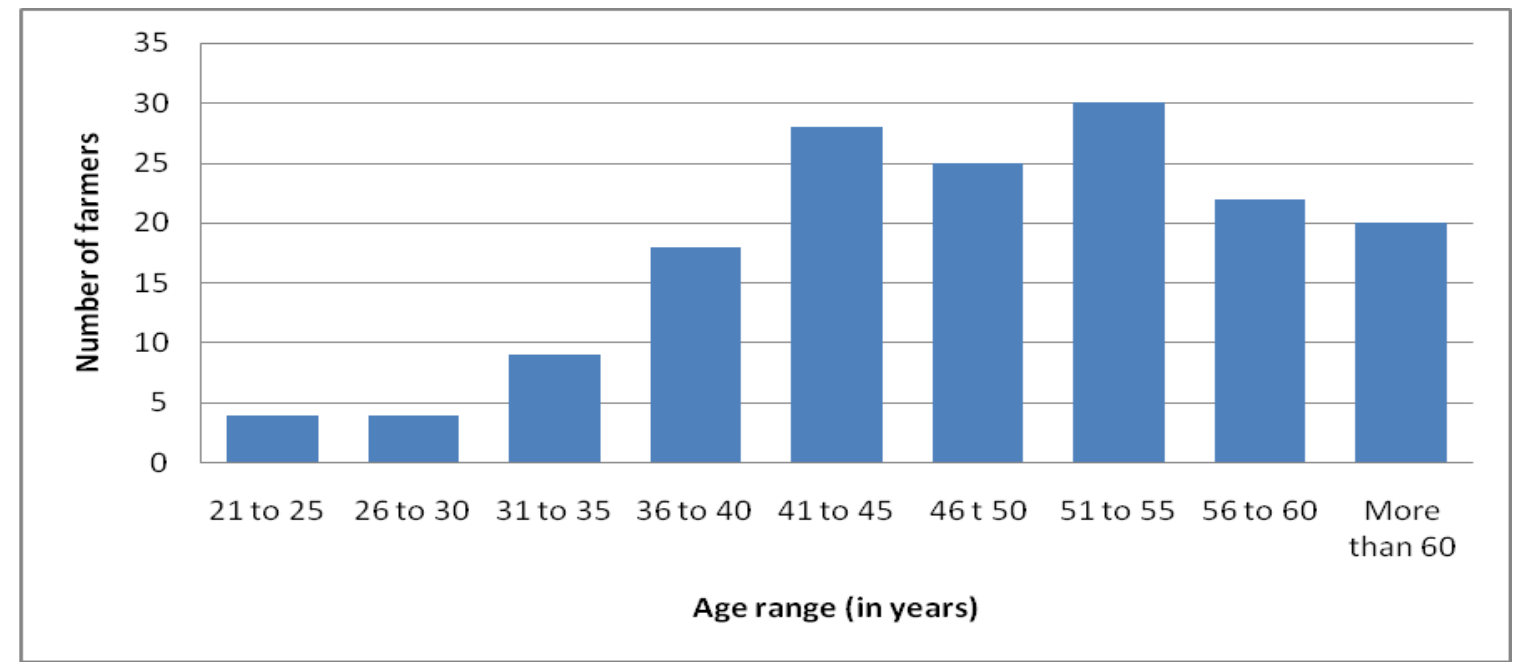

Figure 2. Age distribution of lead farmers in Cameroon.

Most LFs (81 percent) were married, 13 percent were widowed (mostly women), and 4 percent were single. More than half of LFs had education levels above primary school level, and 25 percent had tertiary-level education (Table 4).

Table 4. Educational levels of lead farmers in Cameroon.

\begin{tabular}{|l|c|c|c|}
\hline Education level & Frequencies & Percentages & Cumulative percentages \\
\hline Never been to school & 4 & 2.5 & 2.5 \\
\hline Primary school level & 66 & 41.5 & 44.0 \\
\hline Secondary school level & 50 & 31.4 & 75.5 \\
\hline High school level & 28 & 17.6 & 93.1 \\
\hline University level & 11 & 6.9 & 100.0 \\
\hline Total (missing = 1) & $\mathbf{1 5 9}$ & $\mathbf{1 0 0}$ & \\
\hline
\end{tabular}


Women LFs had lower education levels than men (Figure 3).

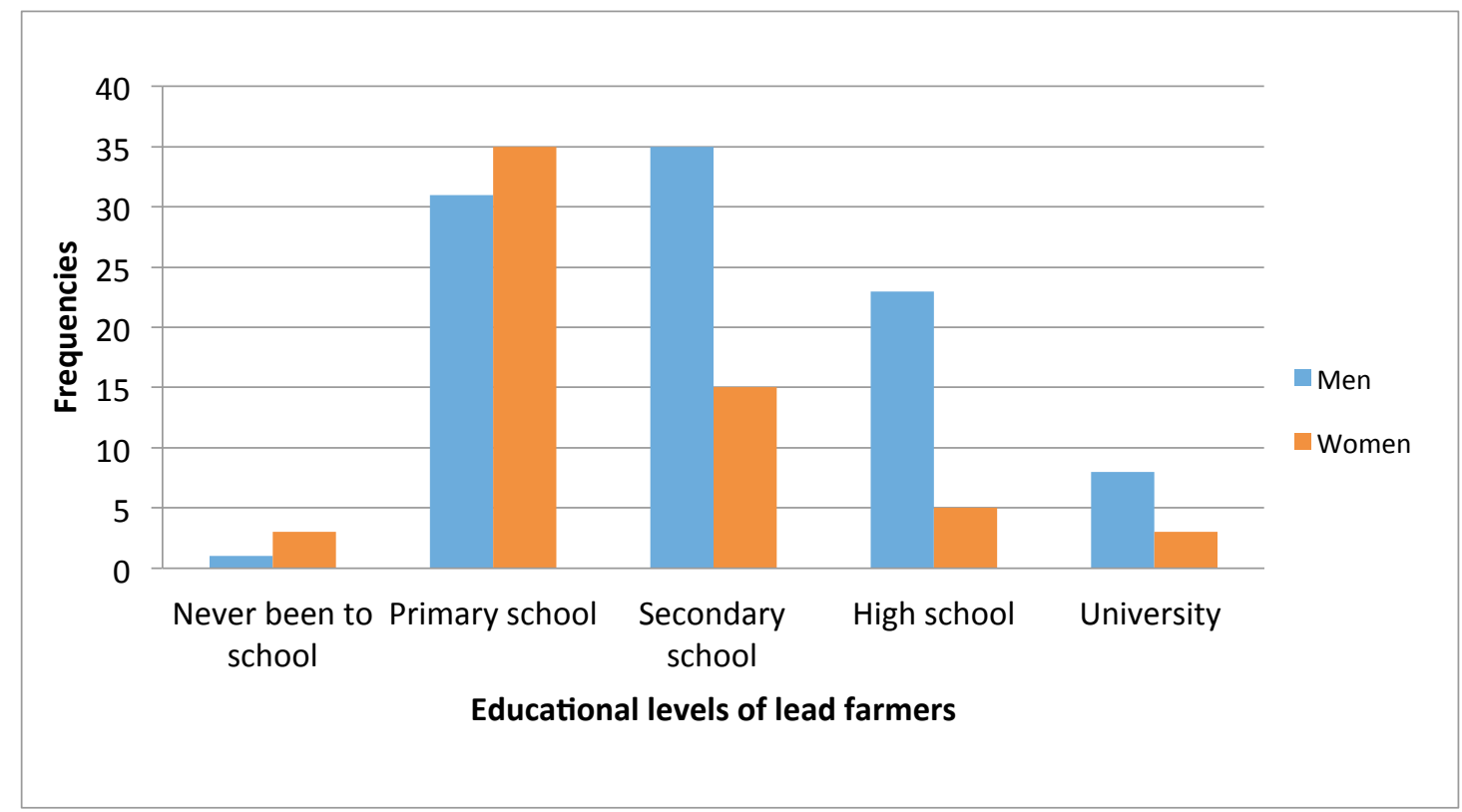

Figure 3. Educational levels of LFs in Cameroon.

In Cameroon, organizations use various titles to designate farmers who train their peers (Figure 4). "Lead farmer" and "farmer trainer" are the most commonly used terms. Some LFs were also called "witness farmers", suggesting that they serve as witnesses to their peers that new technologies are available, accessible and preferable.

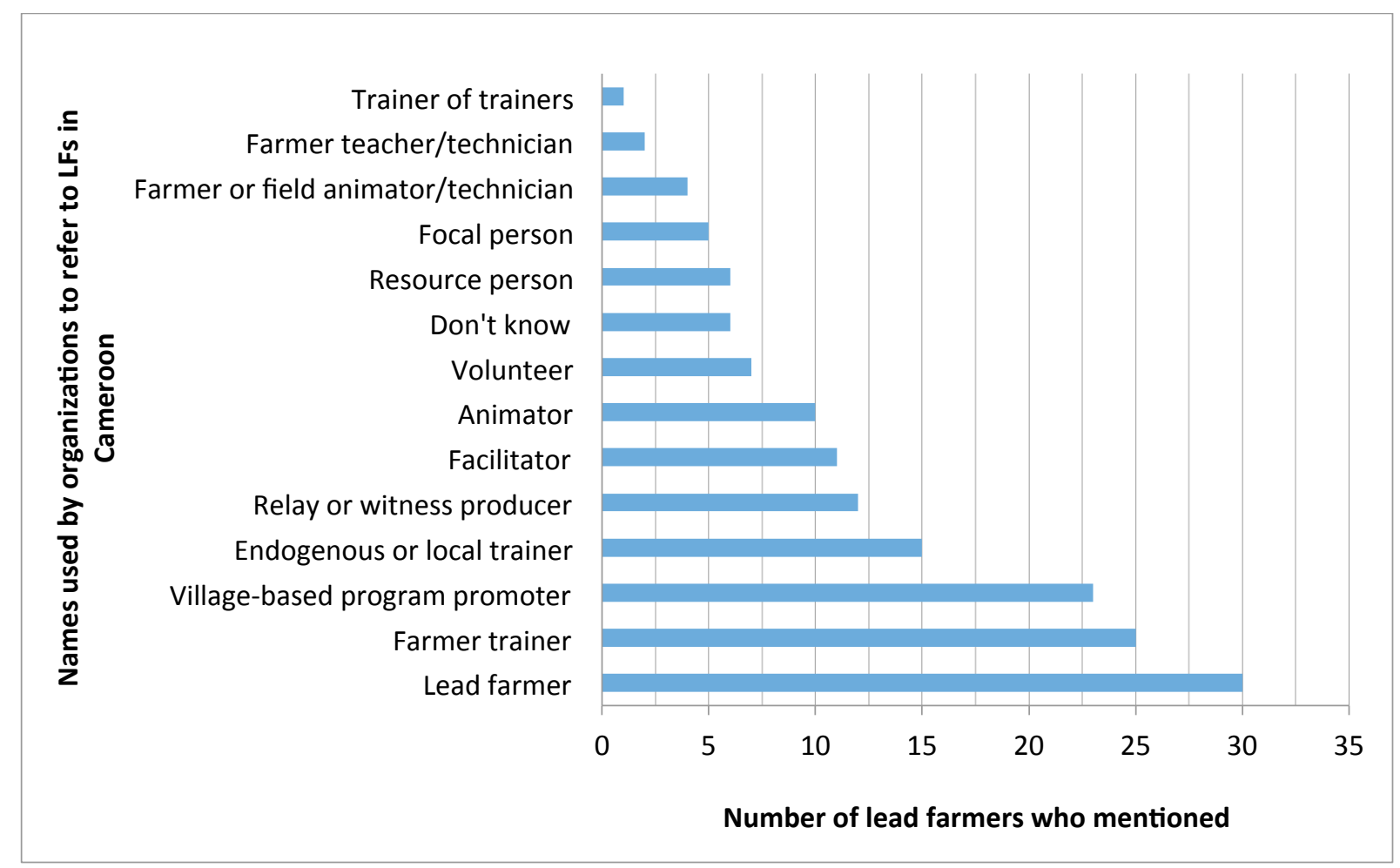

Figure 4. Terms used to refer to lead farmers in Cameroon (according to LFs). 


\section{Selection and training of lead farmers}

The year one became a lead farmer varied, but most of those interviewed started their function between 2005 and 2009, as indicated in Table 5 below. There was no difference between men and women.

Table 5. Year that lead farmers started their function in Cameroon.

\begin{tabular}{|l|c|c|c|c|c|c|}
\hline $\begin{array}{l}\text { Date of } \\
\text { becoming LF }\end{array}$ & $\begin{array}{c}\text { General } \\
\text { frequency }\end{array}$ & $\begin{array}{c}\text { Percentage } \\
\text { (\%) }\end{array}$ & $\begin{array}{c}\text { Men } \\
\text { frequency }\end{array}$ & \% of men & $\begin{array}{c}\text { Women } \\
\text { frequency }\end{array}$ & \% of women \\
\hline 1985 & 1 & 0.6 & 1 & 1.0 & 0 & 0.0 \\
\hline 1992 to 1994 & 5 & 3.1 & 3 & 3.1 & 2 & 3.3 \\
\hline 1995 to 1999 & 15 & 9.4 & 11 & 11.2 & 4 & 6.6 \\
\hline 2000 to 2004 & 19 & 12.0 & 11 & 11.2 & 8 & 13.1 \\
\hline 2005 to 2009 & 72 & 45.3 & 44 & 44.9 & 28 & 45.9 \\
\hline 2010 to 2013 & 47 & 29.6 & 28 & 28.6 & 19 & 31.2 \\
\hline Total & $\begin{array}{c}\mathbf{1 5 9} \\
\text { (Missing }=\mathbf{1})\end{array}$ & $\mathbf{1 0 0}$ & $\begin{array}{c}\mathbf{9 8} \\
\text { (Missing=1) }\end{array}$ & $\mathbf{1 0 0}$ & $\mathbf{6 1}$ & $\mathbf{1 0 0}$ \\
\hline
\end{tabular}

The majority of LFs were selected by their group or community ( 55 percent), followed by selections made by extension field staff members (36 percent). Only one respondent declared that she was selected jointly by the field staff and the farmer group. Among the 13 LFs who were selected by government extension workers or by other respected and experienced lead farmers, nine were women.

Only 14.5 percent of the LFs could not indicate the criteria used for their selection. Others mentioned being an active and hardworking farmer, having good communication skills and being available to other farmers as the most important criteria (Figure 5). Showing interest and the desire to help others and being able to read and write were also frequently cited as important criteria. 


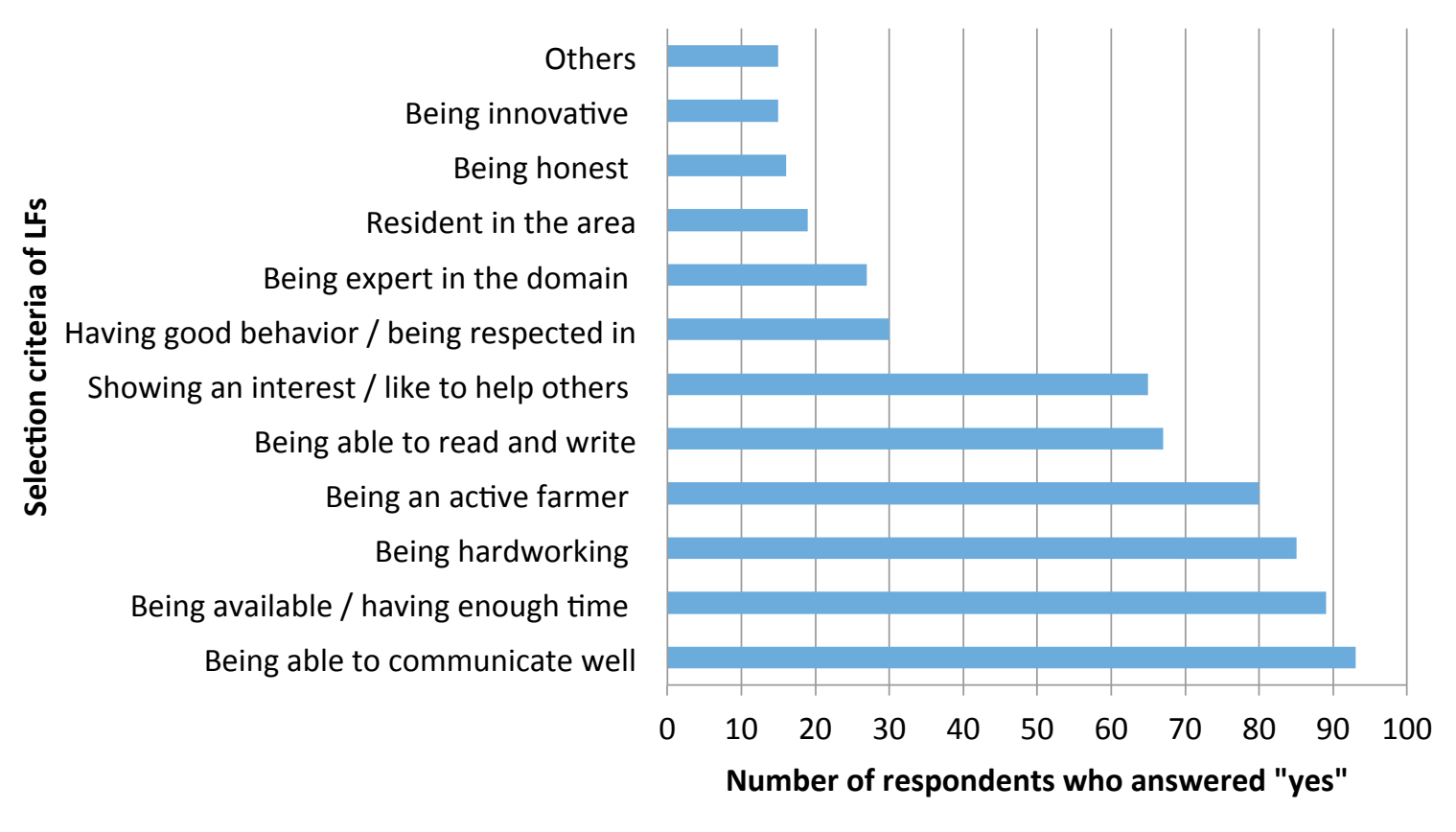

Figure 5. Criteria mentioned by lead farmers in Cameroon as priority for their selection

All but two LFs reported receiving an initial training after selection as a lead farmer. For a majority ( 87.5 percent), this initial training was residential. Others (11.3 percent) reported that their initial training took place on the job during interactions with field staff members. Of this latter group, 81.2 percent were women. The average duration of initial training of LFs was 6.8 days ( $\min =0$ and maximum $=90$ days). However, half of LFs received an initial training of two to three days. One LF said that he received three hours of practical training before starting to train other farmers. The majority of LFs interviewed ( 85 percent) declared that their initial training was related to technical aspects; only 30 percent received training in communication and extension techniques or facilitation skills. Two LFs mentioned that they learned about community development, and two others about group organization. Only one LF was trained on gender issues during his initial training. The majority of LFs ( 82 percent) said that they had also participated in exchange visits as part of their capacity development.

The technical topics covered during the LF initial additional trainings were diverse. Topics in crop-specific production were dominant (42.5 percent), especially for maize, beans, Irish potatoes, cassava, cocoa, ginger, plantain, vegetables, potatoes, yam and rice farming. Training in general agriculture was also important. Twenty-seven percent of LFs received training in subjects that focused on farm management, seed selection, land preparation, soil fertility, farming techniques/integrated cropping, pest control and fence construction. More than one quarter (26 percent) of LFs were also trained in agroforestry, more specifically in tree propagation techniques such as layering, grafting, construction of propagators and rooting by cuttings; nursery management; and on tree planting. As shown in Figure 6, only three LFs 
received training on climate change adaptation, environmental protection or water management.

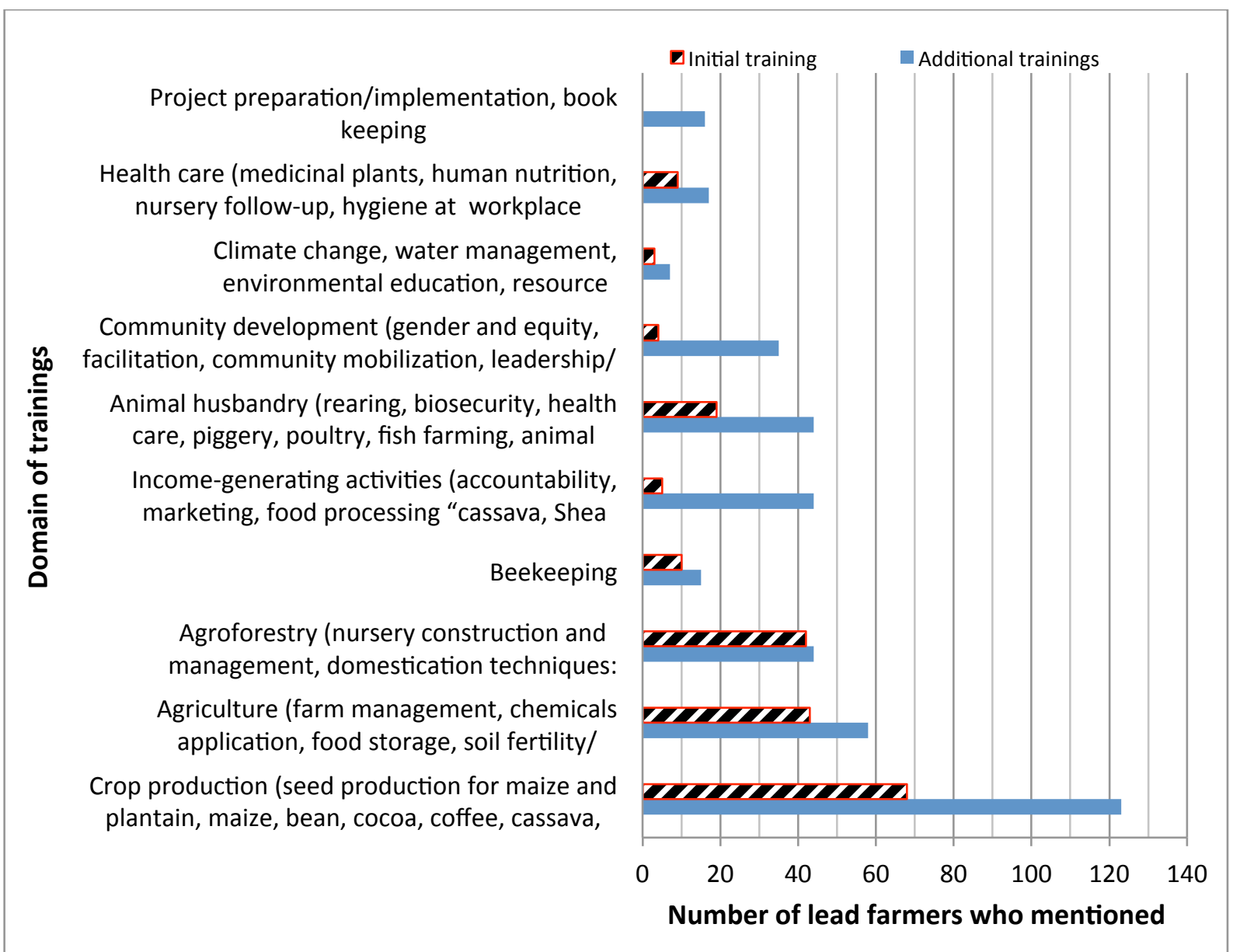

Note: Frequencies add up to over 160 because some lead farmers gave multiple responses.

\section{Figure 6. Technical topics dealt with during LFs' initial and additional trainings.}

After the initial training, most (81 percent) organizations offer LFs additional training. Only 19 percent of respondents did not receive additional training. LFs mentioned that the subjects treated during additional training sessions were much more diverse than those taught during initial training. Table 6 lists the 46 items taught to lead farmers during their initial training, and the 77 topics developed during additional training sessions. Project design/management was not mentioned during additional training; domains such as crop production, incomegenerating activities and leadership were frequently cited (Figure 7). 
Table 6. Subjects taught to lead farmers during initial and additional training sessions.

\begin{tabular}{|c|c|c|}
\hline Domains & $\begin{array}{l}\text { Subtopics during initial } \\
\text { training }\end{array}$ & Subtopics during additional training \\
\hline $\begin{array}{l}\text { Crop } \\
\text { production }\end{array}$ & $\begin{array}{l}\text { Irish potatoes, maize farming, } \\
\text { bean, cassava, cocoa, ginger, } \\
\text { plantain, vegetable, potatoes, } \\
\text { yam, rice farming }\end{array}$ & $\begin{array}{l}\text { Seed production for maize and plantain, maize, } \\
\text { bean, cocoa, coffee, cassava, pineapple, plantain, } \\
\text { rice, potatoes, Gnetum cultivation, mushroom } \\
\text { production; cereals farming/storage; oil palm } \\
\text { cultivation }\end{array}$ \\
\hline $\begin{array}{l}\text { General } \\
\text { agriculture }\end{array}$ & $\begin{array}{l}\text { Farm management, seed } \\
\text { selection, land preparation, soil } \\
\text { fertility, farming } \\
\text { technique/integrated cropping, } \\
\text { pest control, fence construction }\end{array}$ & $\begin{array}{l}\text { Farm management, chemical application, food } \\
\text { storage, soil fertility/composting, fencing, record } \\
\text { keeping, pest control, planning, integrated } \\
\text { cropping }\end{array}$ \\
\hline Agroforestry & $\begin{array}{l}\text { Domestication techniques: } \\
\text { layering, grafting, propagation } \\
\text { from cuttings, nursery, tree } \\
\text { planting, construction of } \\
\text { propagators }\end{array}$ & $\begin{array}{l}\text { Nursery construction and management, } \\
\text { domestication techniques: grafting, layering, } \\
\text { propagation from cutting; tree planting; integrated } \\
\text { farming with trees }\end{array}$ \\
\hline $\begin{array}{l}\text { Animal } \\
\text { husbandry }\end{array}$ & $\begin{array}{l}\text { Feeding, management, pasture } \\
\text { improvement, piggery, poultry, } \\
\text { animals' health care }\end{array}$ & $\begin{array}{l}\text { Rearing, biosecurity, health care, fish farming, } \\
\text { piggery, poultry, animal housing }\end{array}$ \\
\hline Beekeeping & $\begin{array}{l}\text { Hive construction and } \\
\text { installation, honey harvesting }\end{array}$ & $\begin{array}{l}\text { Hive construction and installation, honey } \\
\text { harvesting, wax processing }\end{array}$ \\
\hline Leadership & Group management, facilitation & $\begin{array}{l}\text { Community development, gender and equity, } \\
\text { facilitation, community mobilization, } \\
\text { leadership/group dynamics, children's rights, } \\
\text { conflict management, family planning, } \\
\text { child/sexual abuse, cooperative facilitation, } \\
\text { gender and HIV, youth care }\end{array}$ \\
\hline Health care & $\begin{array}{l}\text { Health and safety, hygiene and } \\
\text { sanitation, medicinal plants }\end{array}$ & $\begin{array}{l}\text { Medicinal plants, human nutrition, nursery } \\
\text { follow-up, hygiene at workplace }\end{array}$ \\
\hline $\begin{array}{l}\text { Natural } \\
\text { resources }\end{array}$ & $\begin{array}{l}\text { Climate change, environmental } \\
\text { protection, water/resource } \\
\text { management }\end{array}$ & $\begin{array}{l}\text { Climate change, water/ resource management, } \\
\text { environmental education, biogas, forest } \\
\text { conservation }\end{array}$ \\
\hline $\begin{array}{l}\text { Income- } \\
\text { generating } \\
\text { strategies }\end{array}$ & Shea butter processing, marketing & $\begin{array}{l}\text { Accountability, marketing, market organization, } \\
\text { food processing (cassava, shea butter, soybeans), } \\
\text { entrepreneurship, fundraising, farm business, } \\
\text { financial management, soap and milk processing }\end{array}$ \\
\hline Project & $\begin{array}{l}\text { Project preparation/ } \\
\text { implementation, bookkeeping }\end{array}$ & \\
\hline
\end{tabular}




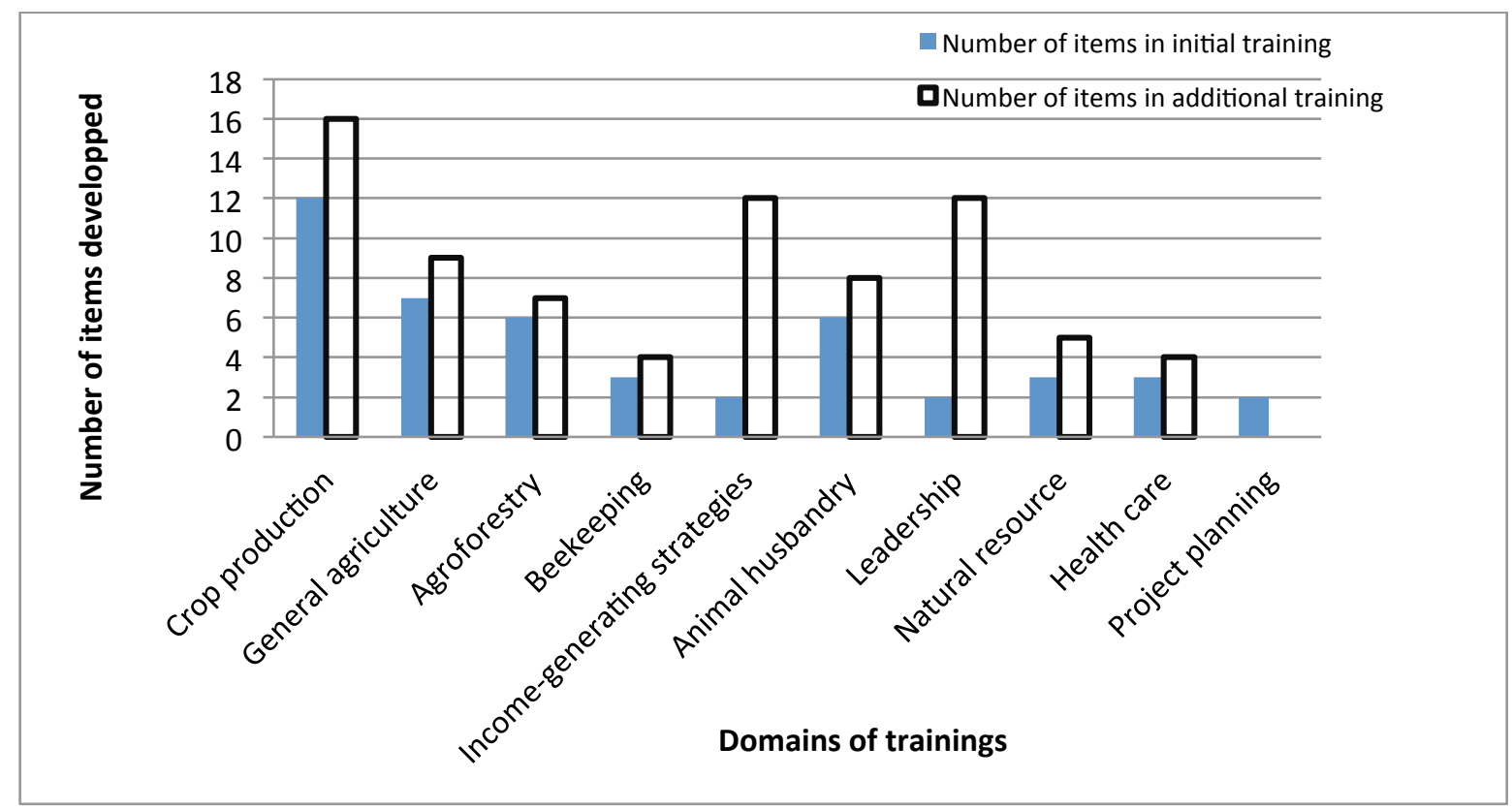

\section{Figure 7. Distribution of items covered during LF training.}

Additional training sessions were mostly (95 percent) residential. Few LFs (4 percent) received additional training through visits of field staff members, and only six LFs indicated that they were trained on the job. Seventeen percent of LFs stated that they had received additional training prior to 2004 (Figure 8); more than half of the LFs had received their last additional training within the past four years.

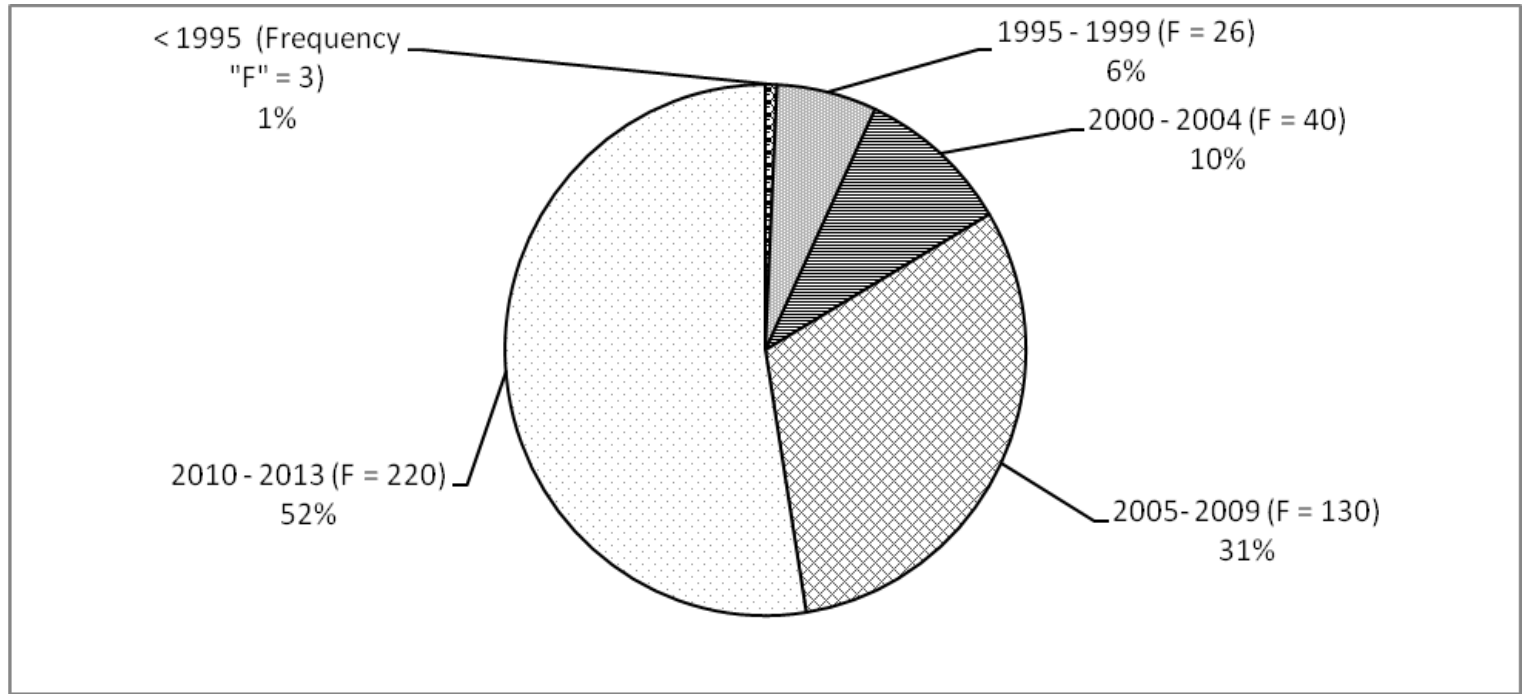

Note: Frequencies add up to over 160 because some lead farmers underwent additional training sessions in the same year.

\section{Figure 8. Timing of additional trainings of lead farmers in Cameroon.}

About a quarter (23 percent) of LFs indicated that they had previous experience in working as lead farmers with other organizations before joining the organization they currently worked with. Twenty-two percent of respondents declared that they were LFs with more than one organization. LFs mentioned 33 organizations that they had previously worked for, in addition 
to the organization they were currently working with. Some organizations prefer to select lead farmers who are lead farmers for other organizations.

\section{Lead farmers' role and activities}

Lead farmers stated that their main roles and activities were to train other farmers, provide technical advice and monitor activities. Some LFs reported organizing follow-up with farmers that they trained through group work on the members' farms. Lead farmers also cited community mobilization for demonstrations or training sessions as part of their responsibilities. Apart from these major functions, LFs also performed many other activities (Figure 9). A few of them were in charge of linking their community with extension workers, and some represented the organization for which they worked within their community. Four LFs mentioned other activities that they had carried out within their zone, such as distributing trees for planting, helping other farmers in marketing their products and conducting feasibility studies. In general, there was no significant difference in responsibilities of LFs between women and men.

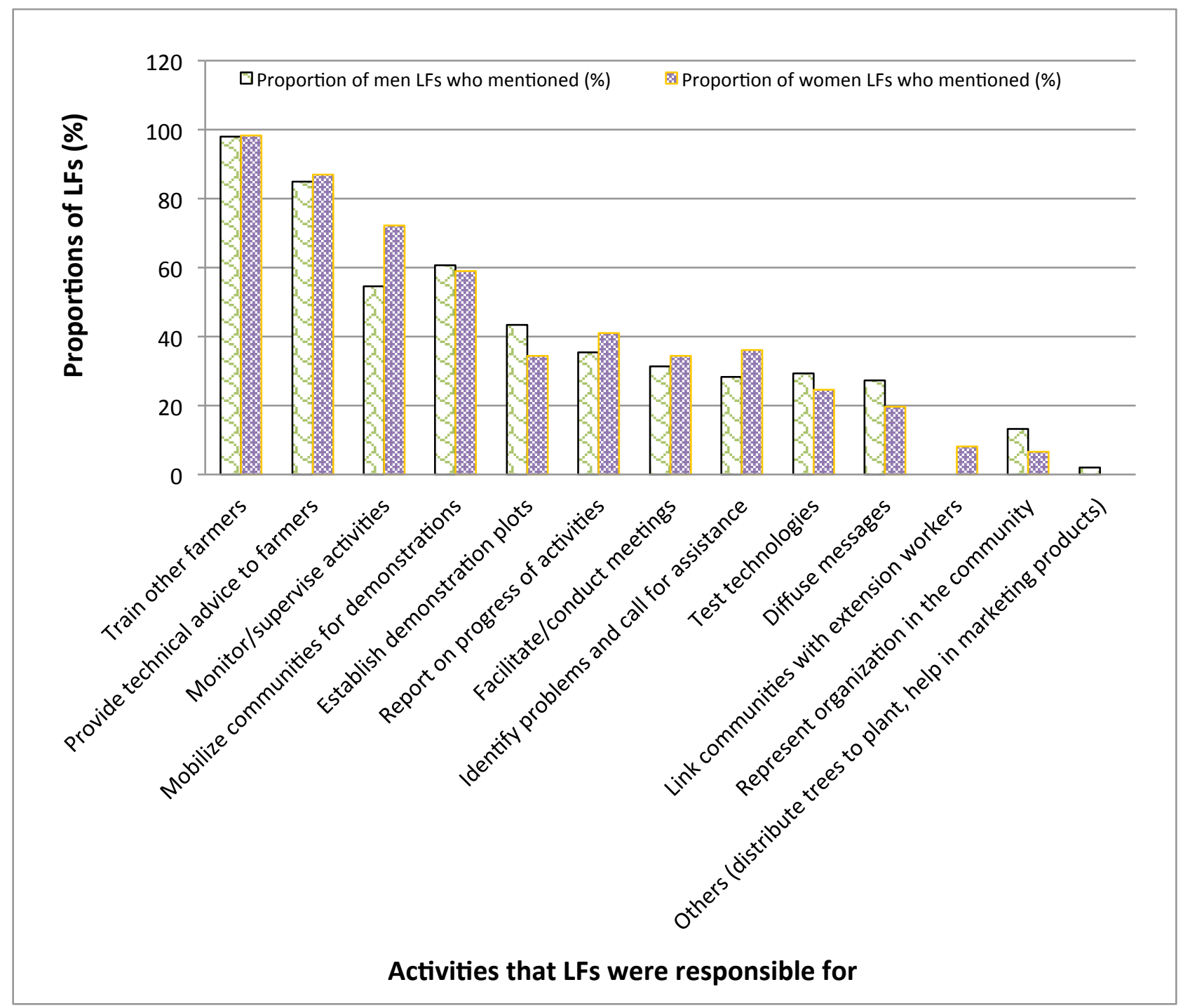

Note: Frequencies add up to over 160 because some lead farmers gave multiple responses. 


\section{Figure 9. Activities carried out by lead farmers in Cameroon.}

Training given by LFs to their peers is categorized into 10 main technical domains (Table 7). The topics taught by lead farmers to other farmers ( 77 topics) were more diverse than the topics they learned about from the organizations that use them as farmer trainers (46 topics). Apart from agroforestry and animal husbandry, where the number of topics taught by LFs was the same as the number received training on, in all other domains the number of issues covered by LFs was greater than the number that they were initially trained on. In health care and leadership, LFs taught double the number of topics of those there were trained on, and in income-generating strategies, they taught five times more topics than they were trained in (that is, eight items more). In crop farming and agriculture/farm management the number of topics taught in addition to those learned was nine and six, respectively, meaning that the proportion was also higher ( 75 percent and 85.7 percent, respectively).

Table 7. Variation between topics taught by LFs to their peers and topics that they were trained on.

\begin{tabular}{|l|c|c|c|}
\hline $\begin{array}{l}\text { Domains of training } \\
\text { given by LFs }\end{array}$ & $\begin{array}{c}\text { Number of topics } \\
\text { LFs were trained } \\
\text { in }\end{array}$ & $\begin{array}{c}\text { Number of topics } \\
\text { taught by LFs to } \\
\text { other farmers }\end{array}$ & $\begin{array}{c}\text { Difference between } \\
\text { number of topics trained in } \\
\text { and number taught }\end{array}$ \\
\hline Crop production & 12 & 20 & 8 \\
\hline $\begin{array}{l}\text { Agriculture / farm } \\
\text { management }\end{array}$ & 7 & 12 & 5 \\
\hline $\begin{array}{l}\text { Income-generating } \\
\text { strategies }\end{array}$ & 2 & 10 & 0 \\
\hline Agroforestry & 6 & 6 & 0 \\
\hline Animal husbandry & 3 & 6 & 2 \\
\hline Beekeeping & 3 & 5 & 1 \\
\hline Natural resources & 3 & 4 & 3 \\
\hline Health care & 2 & 6 & 2 \\
\hline Leadership & 2 & 4 & $\mathbf{3 1}$ \\
\hline Project planning & $\mathbf{4 6}$ & 4 & 2 \\
\hline Total & & $\mathbf{7 7}$ & \\
\hline
\end{tabular}

LFs generally assessed their competencies in the techniques that they trained farmers on as insufficient. However, among the technical topics on which LFs rated themselves, more than half (55.2 percent) rated their competency as "mastered" (Figure 10). In addition, for 13.5 percent of the topics, LFs classified themselves as "experts". About a quarter of the LFs assessed their knowledge as "average" for the innovations that they disseminated; 5.4 percent 
stated that they had only "some" knowledge. Even with limited knowledge, LFs believed they were contributing to the capacity development of their peers.

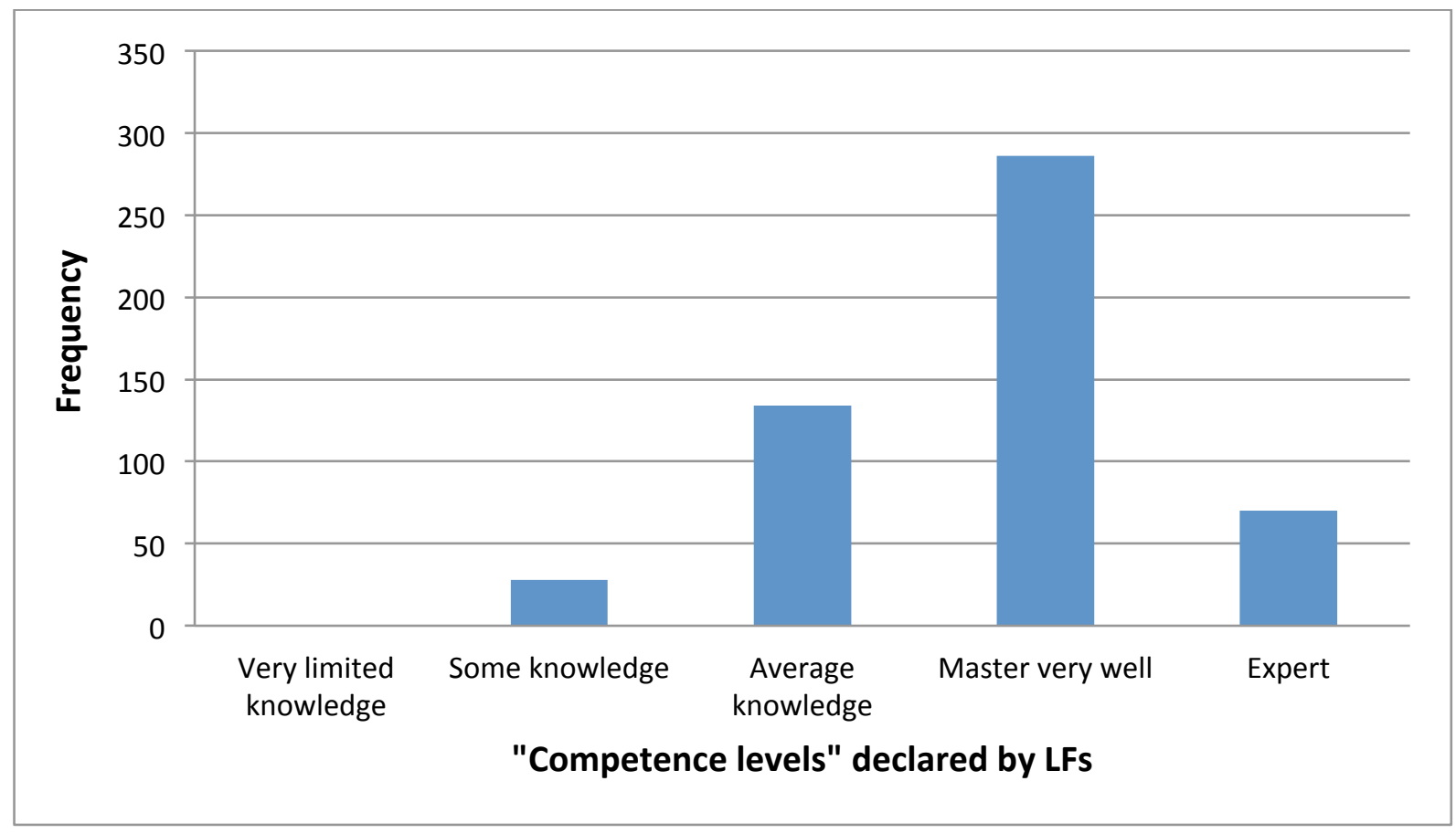

Note: Frequencies add up to over 160 because some lead farmers gave multiple responses.

\section{Figure 10. Competence ratings of lead farmers on topics they trained farmers on.}

The overall average competence level declared by LFs was $3.77 \pm 0.747^{1}$ (on a scale of 1 to 5 ), indicating that LFs felt that they had good mastery of the innovations disseminated. Table 8 gives more detail on the topics taught in various domains. In crop production, for instance, innovation on maize farming was the most widely disseminated, and innovations on maize seed production, rice and mushroom cultivation were the least disseminated crop production topics.

\footnotetext{
${ }^{1}+/-\mathrm{x} \gg$ Indicates 95 percent confidence intervals around an estimate $\mathrm{x}$.
} 
Table 8. Competence ratings declared by LFs on the topics they trained farmers on.

\begin{tabular}{|c|c|c|c|c|}
\hline Domain & Topics taught to farmers by the LF & $\begin{array}{l}\text { Number of } \\
\text { LFs who } \\
\text { mentioned }\end{array}$ & $\begin{array}{c}\text { Average } \\
\text { competence } \\
\text { level }\end{array}$ & $\begin{array}{l}\text { Standard } \\
\text { deviation }\end{array}$ \\
\hline $\begin{array}{l}\text { Crop } \\
\text { production }\end{array}$ & $\begin{array}{l}\text { Cocoa farming } \\
\text { Maize farming } \\
\text { Maize seed multiplication } \\
\text { Cassava farming } \\
\text { Beans cropping } \\
\text { Plantain farming } \\
\text { Plantain multiplication (PIF) } \\
\text { Groundnut farming } \\
\text { General food cropping } \\
\text { Gardening } \\
\text { General seeds selection } \\
\text { Potatoes farming } \\
\text { Coffee farming } \\
\text { Rice farming } \\
\text { Irish potatoes farming } \\
\text { Cocoyam farming } \\
\text { Mushroom cultivation } \\
\text { Other: soybean, onion, etc. }\end{array}$ & $\begin{array}{c}22 \\
40 \\
3 \\
11 \\
12 \\
20 \\
10 \\
4 \\
18 \\
19 \\
5 \\
5 \\
6 \\
3 \\
10 \\
7 \\
3 \\
6\end{array}$ & \begin{tabular}{c|}
3.82 \\
3.67 \\
4.33 \\
3.36 \\
3.33 \\
3.7 \\
3.6 \\
3.75 \\
3.72 \\
3.89 \\
4.2 \\
4.0 \\
3.33 \\
4.33 \\
3.9 \\
3.43 \\
4.33 \\
3.67
\end{tabular} & $\begin{array}{l}0.795 \\
0.829 \\
0.577 \\
0.924 \\
0.651 \\
0.657 \\
0.516 \\
1.258 \\
0.575 \\
0.809 \\
0.447 \\
0.707 \\
0.816 \\
1.155 \\
0.876 \\
0.787 \\
0.577 \\
0.516\end{array}$ \\
\hline $\begin{array}{l}\text { Agriculture/ } \\
\text { Farm } \\
\text { management }\end{array}$ & $\begin{array}{l}\text { Composting } \\
\text { Chemical/fertilizer application } \\
\text { General farm management } \\
\text { Crop association } \\
\text { Crop protection } \\
\text { Soil conservation } \\
\text { Food storage }\end{array}$ & $\begin{array}{c}11 \\
15 \\
20 \\
5 \\
8 \\
30 \\
8\end{array}$ & $\begin{array}{c}4 \\
3.87 \\
3.9 \\
3.6 \\
3.87 \\
3.67 \\
3.5 \\
\end{array}$ & $\begin{array}{l}0.632 \\
0.640 \\
0.641 \\
0.548 \\
0.641 \\
0.758 \\
0.756\end{array}$ \\
\hline Agroforestry & $\begin{array}{l}\text { General domestication techniques } \\
\text { Tree planting } \\
\text { Propagation from cuttings } \\
\text { Nursery construction/management } \\
\text { Grafting } \\
\text { Marcotting }\end{array}$ & $\begin{array}{c}21 \\
12 \\
4 \\
11 \\
4 \\
7\end{array}$ & $\begin{array}{c}3.71 \\
3.42 \\
3.5 \\
4.09 \\
3.5 \\
3.57\end{array}$ & $\begin{array}{l}0.845 \\
0.900 \\
0.577 \\
0.539 \\
0.577 \\
0.787\end{array}$ \\
\hline $\begin{array}{l}\text { Income- } \\
\text { generating } \\
\text { strategies }\end{array}$ & $\begin{array}{l}\text { Marketing of products } \\
\text { Product processing }\end{array}$ & $\begin{array}{l}10 \\
19\end{array}$ & $\begin{array}{l}3.8 \\
4.16\end{array}$ & $\begin{array}{l}0.632 \\
0.688\end{array}$ \\
\hline $\begin{array}{l}\text { Animal } \\
\text { husbandry }\end{array}$ & $\begin{array}{l}\text { General breeding } \\
\text { Fish farming } \\
\text { Cow and goat breeding } \\
\text { Piggery } \\
\text { Poultry }\end{array}$ & $\begin{array}{c}10 \\
4 \\
11 \\
15 \\
17\end{array}$ & $\begin{array}{c}3.9 \\
4.25 \\
3.91 \\
3.73 \\
3.65\end{array}$ & $\begin{array}{c}0.568 \\
0.5 \\
1.044 \\
0.594 \\
0.786\end{array}$ \\
\hline
\end{tabular}




\begin{tabular}{|l|l|c|c|c|}
\hline Domain & Topics taught to farmers by the LF & $\begin{array}{c}\text { Number of } \\
\text { LFs who } \\
\text { mentioned }\end{array}$ & $\begin{array}{c}\text { Average } \\
\text { competence } \\
\text { level }\end{array}$ & $\begin{array}{c}\text { Standard } \\
\text { deviation }\end{array}$ \\
\hline Apiculture & Traditional and intermediate beekeeping & 23 & 4.09 & 0.668 \\
\hline Environment & Environmental conservation & 6 & 4.12 & 1.035 \\
Leadership & Bookkeeping and reporting & 6 & 3.33 & 0.816 \\
& Group/conflicts/resource management) & 11 & 3.64 & 0.674 \\
& Gender issues and HIV/AIDS awareness & 5 & 4.0 & 0.816 \\
\hline Health & Community health (food & 7 & 3.71 & 0.951 \\
& hygiene/consumption, health, safety) & 10 & 3.7 & 0.823 \\
\hline Project & Medicinal plants (cultivation and usage) & 3 & 4.0 & 0 \\
\hline
\end{tabular}

Ninety-three percent of the trainings organized by LFs focused on practical skill development, and 91 percent of LFs believed that these techniques were actually applied by the trainees.

Lead farmers were using many strategies to identify the training needs of their fellow farmers. Most often (67 percent), LFs organized training sessions on themes requested by farmers. Some respondents (15 percent) mentioned that field staff members identified the content of trainings to be carried out. A very small proportion of LFs (3 percent) were simply delivering what they learned during their training. Many LFs, however, were innovative and used general meetings or other training sessions as well as their own appraisal to identify training needs of their peers (Figure 11). For instance, a lead farmer reported that her training contents were based on the agricultural calendar. Another one stated that training modules were given by the organization that trained them. Though there was no real difference in identifying training needs following farmers' requests ( 68 percent men against 66 percent women), female LFs used their own appraisal more than men LFs did. For instance, 34 percent of women used this method compared with 25 percent of their male counterparts. Also, 38 percent of women LFs used general meetings or training sessions to identify the training needs of their fellow farmers, while 27 percent of men did so.

The finding that farmers trained based on needs assessments and not just on what the organization taught them is reinforced by the findings in Table 7 that they taught farmers more topics than they learned during training. As some of them served as lead farmers for other organizations, they may also have been training farmers in subjects they learned from those other organizations. 


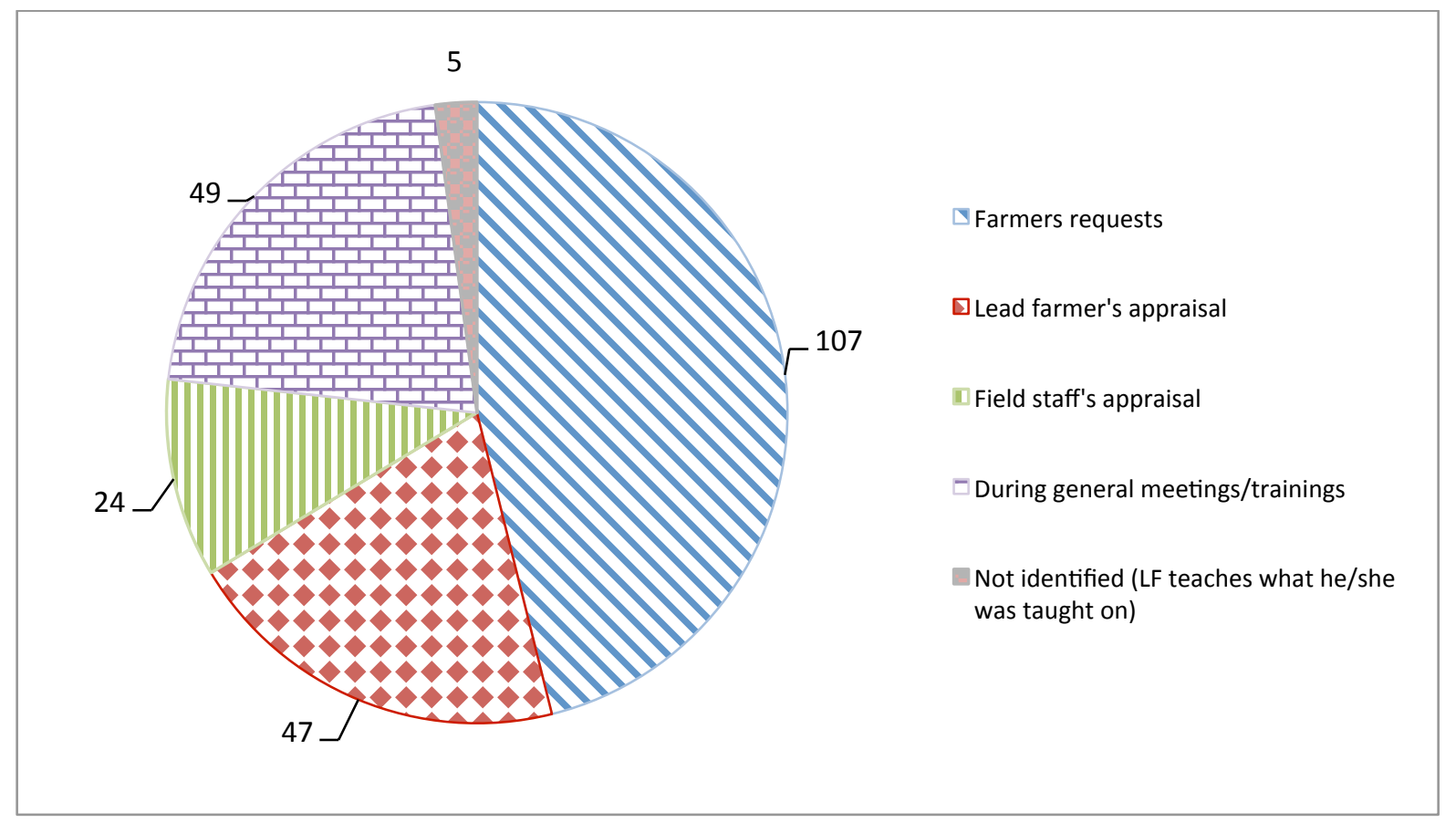

Note: Frequencies add up to over 160 because some lead farmers gave multiple responses.

Figure 11. Frequencies of methods used for identifying training needs of farmers by LFs.

The majority of LFs (84 percent) were serving organized groups; 26 percent were serving communities or villages. In addition, around 60 percent were also training individuals. Here, women were more active -70 percent of them were training individuals compared with 57 percent of men LFs.

Around one-third (32 percent) of LFs worked with only one group, i.e., the group to which they belonged. More women LFs than men were working with only one group (42 percent and 26 percent, respectively). On average, LFs worked with five groups. Three LFs declared that they were working with 40 to 50 groups. These LFs were asked by many organizations to train farmer groups in their projects. Table 9 shows that more than one-third (36 percent) of LFs were working with four or more groups. In this category, men were more involved (42 percent) than women LFs (28 percent), perhaps because men were able to spend more time away from their families.

Table 9. Number of groups a lead farmer worked with.

\begin{tabular}{|l|c|c|c|c|}
\hline $\begin{array}{l}\text { Number of } \\
\text { groups }\end{array}$ & Frequency & $\begin{array}{c}\text { General } \\
\text { proportion } \\
\text { (percent) }\end{array}$ & $\begin{array}{c}\text { Proportion men } \\
\text { (percent) « } \mathbf{N}= \\
\mathbf{9 9} \text { » }\end{array}$ & $\begin{array}{c}\text { Proportion women } \\
\text { (percent) « N = 61 » }\end{array}$ \\
\hline 0 & 5 & 3.1 & 2 & 5 \\
\hline 1 & 51 & 31.9 & 26.5 & 41.7 \\
\hline 2 & 21 & 13.1 & 14.3 & 11.7 \\
\hline 3 & 23 & 14.4 & 15.3 & 13.3 \\
\hline 4 & 16 & 10 & 13.3 & 5 \\
\hline
\end{tabular}




\begin{tabular}{|l|c|c|c|c|}
\hline $\begin{array}{l}\text { Number of } \\
\text { groups }\end{array}$ & Frequency & $\begin{array}{c}\text { General } \\
\text { proportion } \\
\text { (percent) }\end{array}$ & $\begin{array}{c}\text { Proportion men } \\
\text { (percent) } \text { « } \mathbf{N}= \\
\mathbf{9 9} »\end{array}$ & $\begin{array}{c}\text { Proportion women } \\
\text { (percent) } \text { « } \mathbf{N}=\mathbf{6 1} \text { » }\end{array}$ \\
\hline 5 to 7 & 18 & 11.4 & 9.2 & 15 \\
\hline 8 to 10 & 11 & 7 & 10.1 & 1.7 \\
\hline 11 to 25 & 10 & 6.3 & 6 & 6.7 \\
\hline 40 to 50 & 3 & 1.8 & 3 & 0 \\
\hline
\end{tabular}

Several variables were associated with the number of groups an LF trained. When LFs were members of many groups, they tended to train more groups (Table 10). The greater their education level, the more groups that LFs trained (Table 11). There was no association between age and number of groups trained (Table 12).

Table 10. Number of groups trained by lead farmers based on the number of groups they belonged to.

\begin{tabular}{|c|c|c|c|}
\hline \multirow{2}{*}{$\begin{array}{c}\text { Number of other groups where } \\
\text { respondent is member }\end{array}$} & \multicolumn{3}{|c|}{ Number of groups trained } \\
\cline { 2 - 4 } & Mean & $\mathbf{N}$ & Std. Deviation \\
\hline 0 & 3.1 & 76 & 3.727 \\
1 & 4.7 & 48 & 7.902 \\
2 & 4.5 & 19 & 2.318 \\
3 & 11.8 & 11 & 14.358 \\
4 & 10.0 & 1 & 0.000 \\
6 & 21.5 & 2 & 26.163 \\
\hline
\end{tabular}

Table 11. Number of groups trained by a lead farmer based on educational level.

\begin{tabular}{|l|c|c|c|}
\hline Educational level of respondent & Mean & N & Std. Deviation \\
\hline Never been to school & 1.0 & 4 & 0.000 \\
Primary school & 3.0 & 65 & 3.674 \\
Secondary school & 4.5 & 50 & 4.883 \\
High school & 7.3 & 28 & 10.985 \\
University & 10.9 & 10 & 15.037 \\
\hline
\end{tabular}


Table 12. Correlation of some factors with number of groups trained by lead farmers.

\begin{tabular}{|c|c|c|c|c|c|}
\hline & & $\begin{array}{l}\text { Number of } \\
\text { groups or } \\
\text { communities } \\
\text { the respondent } \\
\text { works with }\end{array}$ & $\begin{array}{l}\text { Age range } \\
\text { of } \\
\text { respondent }\end{array}$ & $\begin{array}{l}\text { Education } \\
\text { level of } \\
\text { respondent }\end{array}$ & $\begin{array}{l}\text { Number of } \\
\text { other groups } \\
\text { that } \\
\text { respondent is } \\
\text { involved in }\end{array}$ \\
\hline \multirow[t]{2}{*}{$\begin{array}{l}\text { Number of groups } \\
\text { or communities } \\
\text { that the } \\
\text { respondent works } \\
\text { with }\end{array}$} & \begin{tabular}{|l|} 
Pearson \\
Correlation \\
Sig. (2- \\
tailed)
\end{tabular} & 1 & $\begin{array}{l}-0.082 \\
0.305\end{array}$ & $\begin{array}{l}0.312^{*} \\
0.000\end{array}$ & $\begin{array}{l}0.361^{*} \\
0.000\end{array}$ \\
\hline & $\mathrm{N}$ & 158 & 158 & 157 & 157 \\
\hline
\end{tabular}

The average group size that LFs reported working with was 26.3 farmers. Though some LFs were not working with groups, as we mentioned earlier, some (two) were working with groups of around 600 farmers. The majority (69 percent) of LFs worked with groups of 10 to 29 farmers (Figure 12).

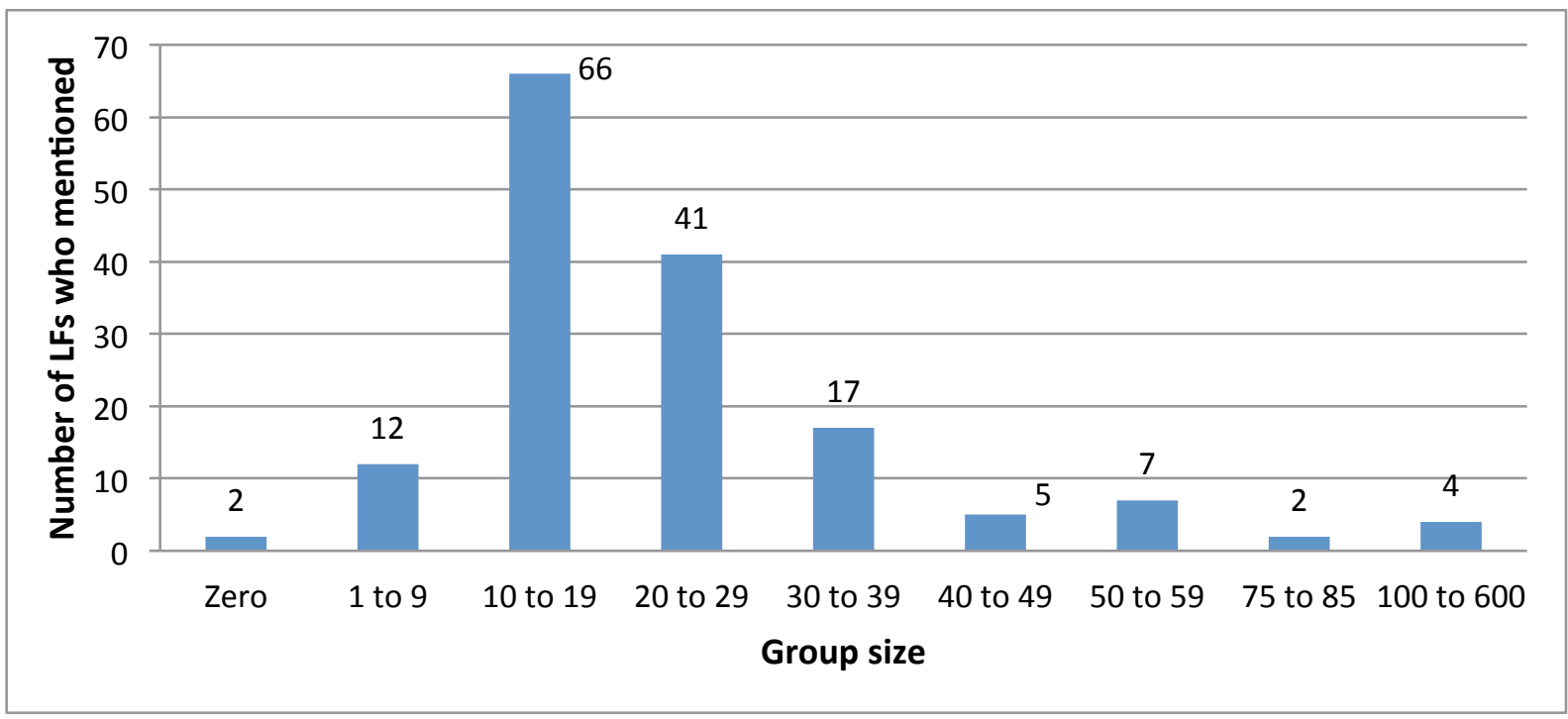

Figure 12. Distribution of the sizes of groups that lead farmers worked with.

The average number of farmers trained by a lead farmer in groups at the time this survey took place was 116.4 farmers $(\min =0$ and $\max =4200$, median $=50)$. The total number of trainees reached by LFs through group training at the time the survey took place was 18,387 , from a total of 735 farmer groups.

The average number of groups trained by men was greater than that of women LFs $(\mathrm{P}(\mathrm{t})=$ $0.072)$. Women trained on average 3.3 groups $(\min =0$ and $\max =25)$ compared with men 
LFs, who trained an average of 5.6 groups $(\min =0$ and $\max =50)$. The total number of farmers trained did not vary by gender $(\mathrm{P}(\mathrm{t})=0.738)$.

LFs also trained individual farmers, those not members of any group. Each LF trained on average an additional 37.1 individual farmers $(\min =0$ and $\max =600$, median $=10)$. In general, LFs at the time of the survey had trained an average of 153.9 farmers (median $=66$ ) to whom they had disseminated at least one innovation.

Around one-third of lead farmers (30 percent) met their trainees weekly. The majority of LFs (61.5 percent) met with individuals on request (Table 13). Though there was no significant difference in frequency of contacts by gender, women LFs tended to meet individual farmers on a less regular basis than their male counterparts.

Table 13. Frequencies of follow-up visits with trainees by lead farmers.

\begin{tabular}{|l|c|c|c|c|}
\hline \multirow{2}{*}{ Meeting interval } & \multicolumn{2}{|c|}{ With groups } & \multicolumn{2}{c|}{ With individuals } \\
\cline { 2 - 5 } & Frequency & Percentage & Frequency & Percentage \\
\hline No meeting & 1 & 0.6 & 1 & 0.8 \\
Once or twice a week & 47 & 30.3 & 12 & 9.2 \\
Dependent on season & 15 & 9.7 & 18 & 13.8 \\
/not regular & & & & \\
Go by action plan & 11 & 7.1 & 4 & 3.1 \\
Once a month & 45 & 29 & 7 & 5.4 \\
Twice a month & 15 & 9.7 & 5 & 3.8 \\
On request & 12 & 7.7 & 80 & 61.5 \\
Other & 9 & 5.8 & 3 & 2.3 \\
\hline Total & $155(\mathrm{missing}=5)$ & 100 & $130(\mathrm{missing}=30)$ & 100 \\
\hline
\end{tabular}

A majority of LFs (59 percent) trained farmers in their group or community hall, and male LFs preferred this option more than female LFs. In addition, around half (48 percent) of the LFs used the trainees' farms or houses for training. Many (40 percent), particularly women, also trained farmers at their houses or farms (Figure 13). 


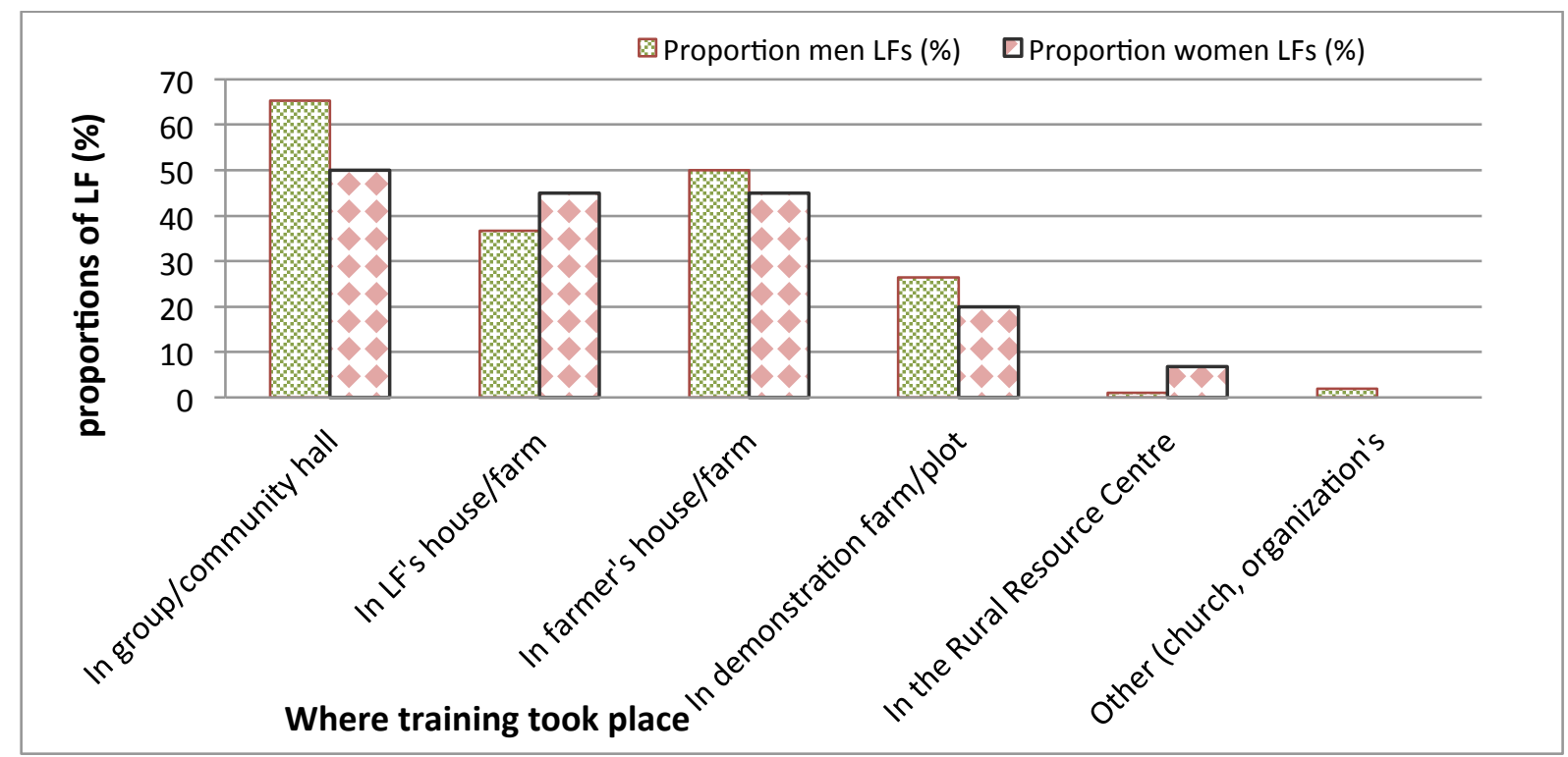

Note: Frequencies add up to over 160 because some lead farmers gave multiple responses.

Figure 13. Places where lead farmers trained farmers.

To get to locations where they conducted trainings, LFs most often walked, as shown in Figure 14. Those using motorbikes were almost always men; only one woman LF was using a motorbike.

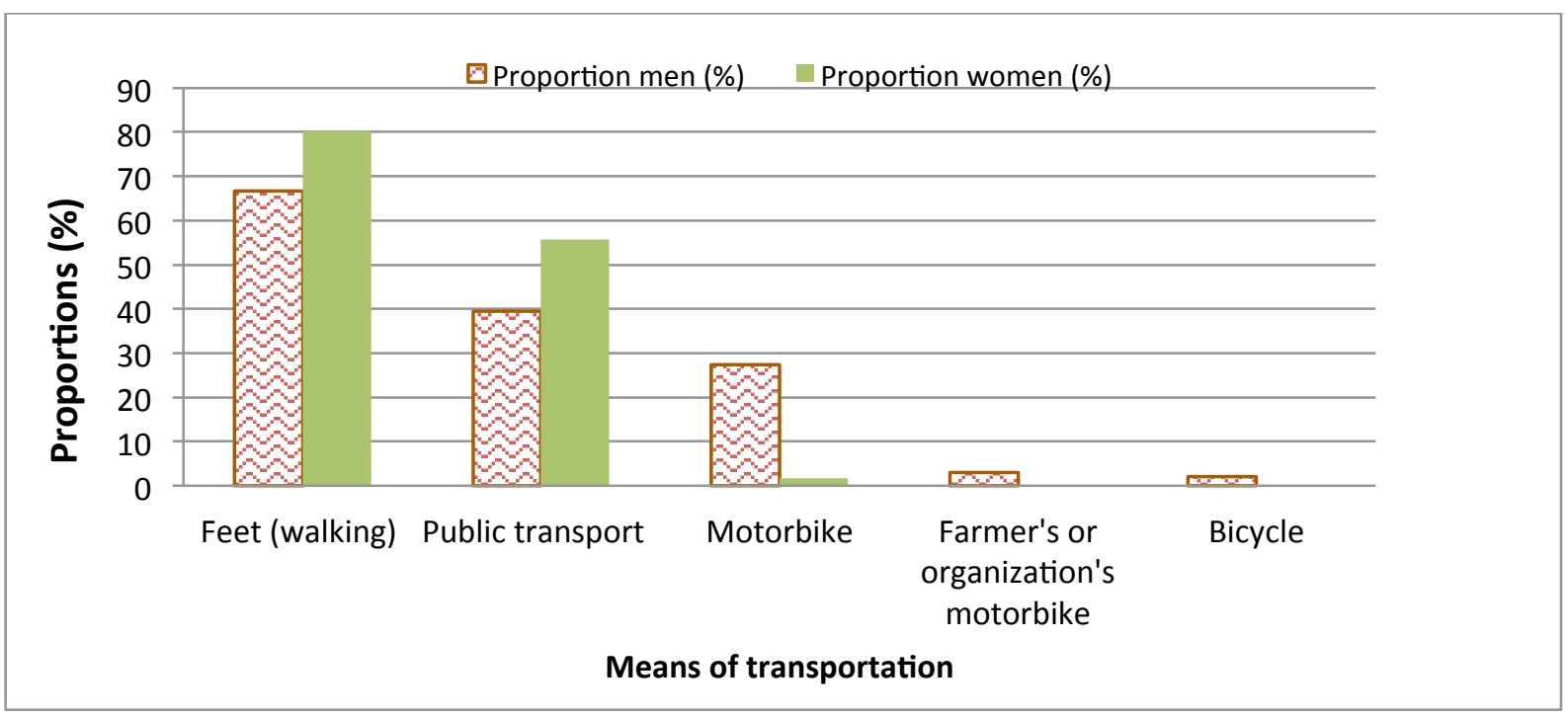

Note: Frequencies add up to over 160 or 100 percent because some lead farmers gave multiple responses.

\section{Figure 14. Means of transportation used by lead farmers to meet trainees.}

LFs paid their transportation costs in 58 percent of the cases. There was no association between payment of transport fees and LFs' gender. The proportion of total transportation cost paid by LFs was 46.1 percent $(\min =0, \max =100$, median $=45.8)$. Although 54 percent of LFs declared that they were paying the total of their transportation cost to train their peers, 
more than one quarter ( 27 percent) of the LFs also stated that transport costs were generally paid for by the farmer or group that called upon their services. Only17 percent of LFs' transportation costs were supported by the organizations sponsoring their activities (Table $14)$.

LFs reported using many types of communication to interact with trainees (Figure 15). The most common was the use of personal cellphones. However, other means of communication were also popular, such as letters, usually sent via public transport going to their working areas. Some LFs also arranged subsequent appointments at the end of a training session or meeting. LFs used a range of opportunities to inform their trainees. For instance, contacts made during market days, village announcement boards, posters, churches and other ceremonies.

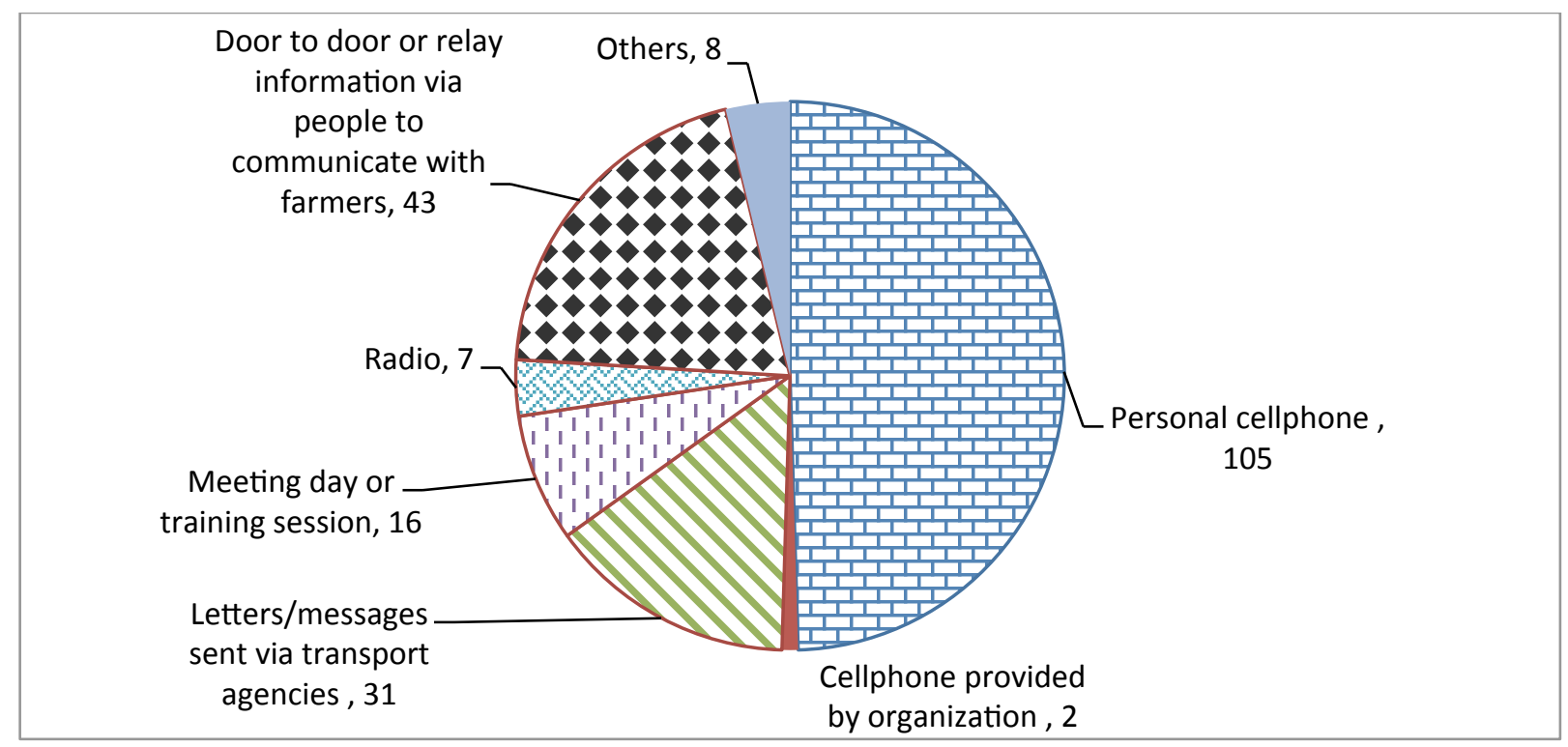

Note: Frequencies add up to over 160 because some lead farmers gave multiple responses.

Figure 15. Types of communication used by LFs to interact with farmers (in number of LFs using that type of communication).

Though LFs mostly used their personal cellphones to communicate with farmers and field staff respectively, the proportion of men LFs that used it was greater than women LFs (70 percent versus 60 percent, and 74 percent versus 64 percent respectively).

The proportion of LFs paying all or part of the communication costs when they are interacting with trainees was quite high (67.4 percent). Fifty-four percent of respondents stated that they paid at least 10 percent of their total communication expenses; on average, LFs paid 46 percent of the communication costs $(\min =0, \max =100$, median $=45.8)$. Men LFs were spending more than women on communication. Men LFs contributed 48.4 percent (median = 50) compared with 42.5 percent (median $=10)$ for women LFs. 
As indicated in Table 14, very few LFs (10.4 percent) had their communication expenses paid for by the organizations they were working for. More men LFs (17.6 percent) received funds for communication from the groups they visited than did women LFs (12 percent).

Table 14. Payment of transportation and communication costs of LFs to interact with farmers.

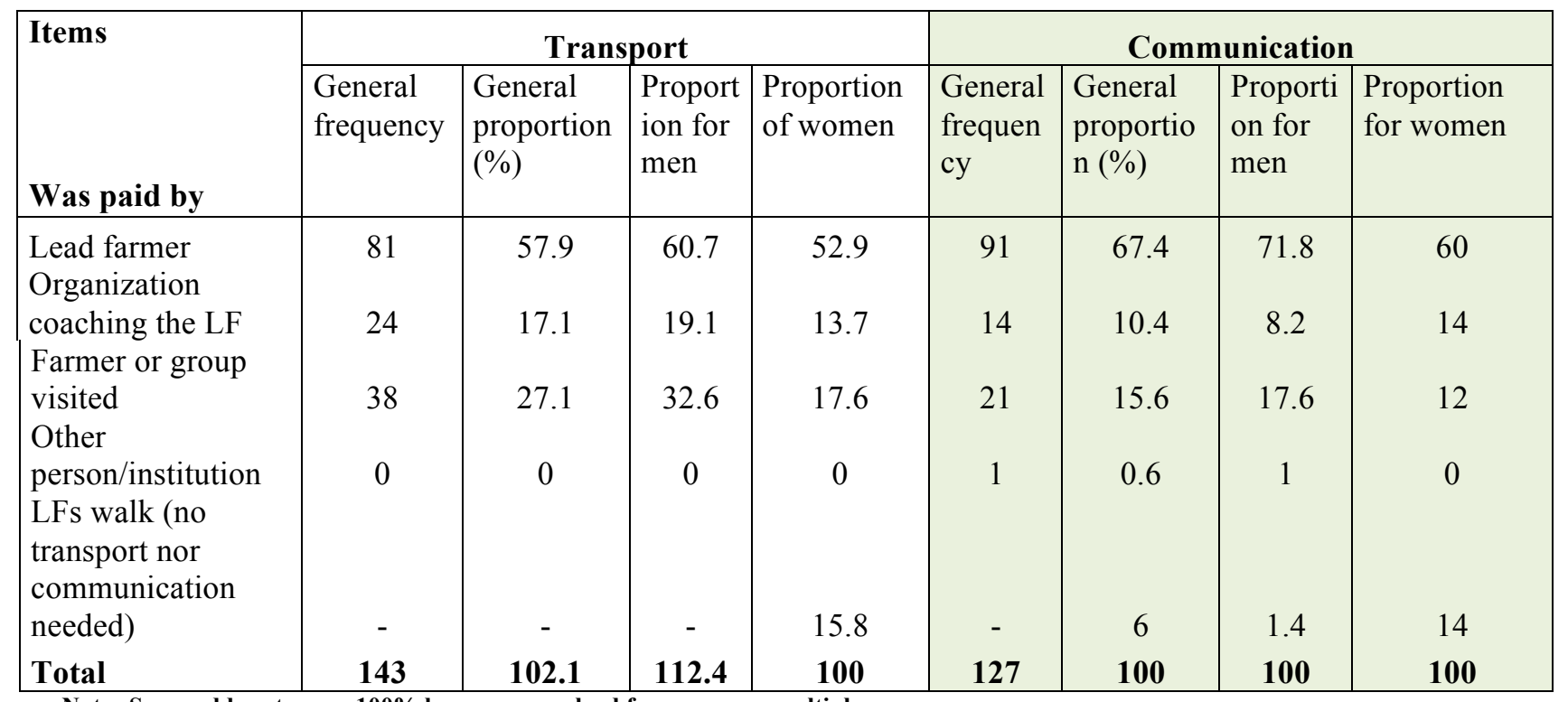

Note: Some add up to over $100 \%$ because some lead farmers gave multiple responses.

The majority of LFs (68.8 percent) said that they kept records of their activities. But only 33\% kept written records; two-thirds of those who indicated that they kept records did not record information in written form - rather, they shared information orally during feedback meetings with field staff members. Record keeping was done more by men ( 74.7 percent) than women LFs (59 percent). Lead farmers mainly kept records for reporting to their supervisors. Records were kept mainly on training and follow-up data. Reporting on finance and production statistics was mentioned by only a few lead farmers. Many LFs (31 percent) did not report, either because they lacked literacy, or they did not know to whom they should report. So, lack of literacy skills and/or the communication channels were obstacles for LFs reporting. In addition, some LFs declared that they did not keep records - for instance, keeping a training attendance list - because they were not asked to do so. One LF said that he writes reports when trainees are sent to him by an organization. In other cases, he just evaluates the farmer after training, without any written report. Unless LFs are required to keep records and trained to do so, it is not reasonable to expect them to keep records on their own. 


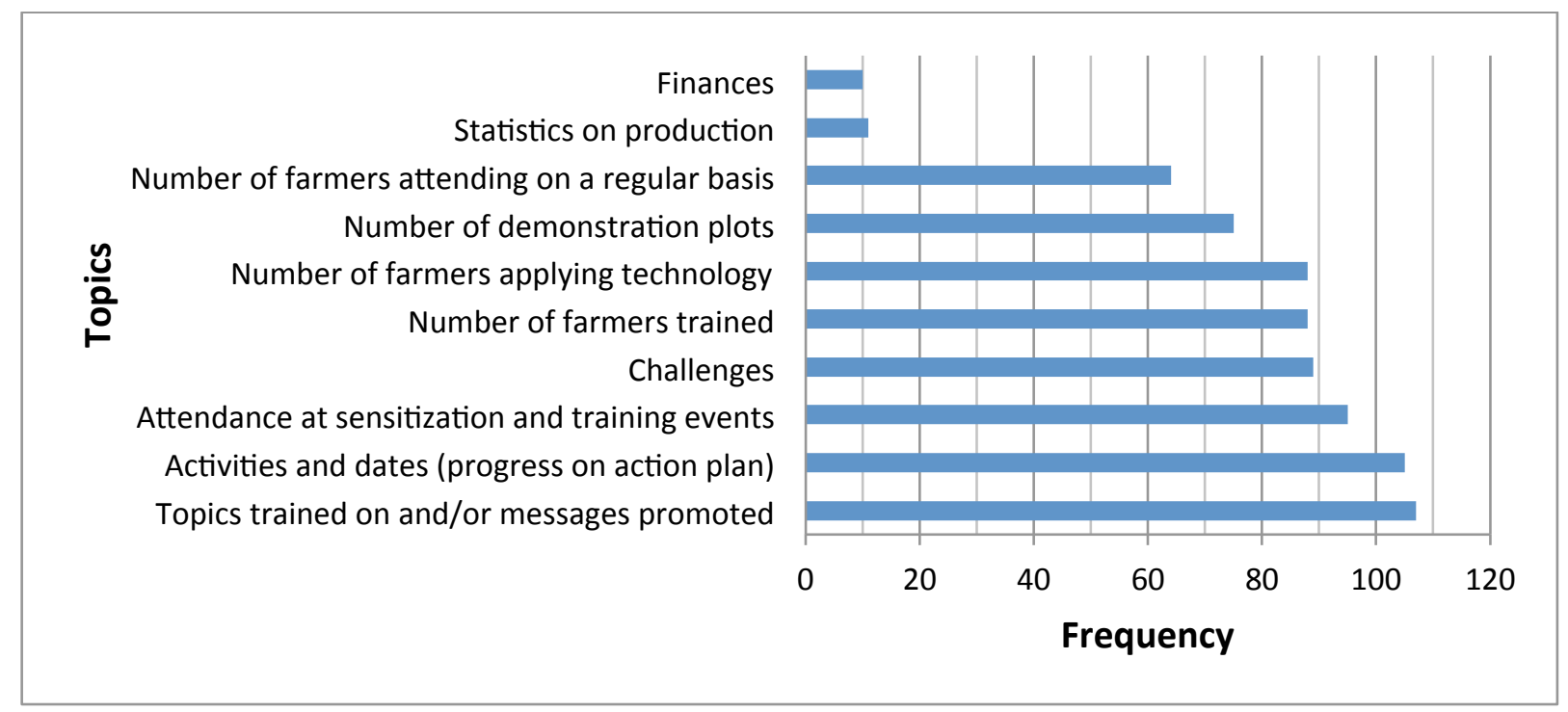

Note: Frequencies add up to over 160 because some lead farmers gave multiple responses.

\section{Figure 16. Topics on which lead farmers kept records.}

\section{Support to lead farmers}

Most LFs (79 percent) are supervised by field staff members of the organizations supporting them. Most of the remaining lead farmers (16 percent) were not supervised at all, 3 percent were supervised by their group or community, and 2 percent by government extension workers. Among the 79 percent monitored by field staff, 42 percent were supervised by more than one staff member.

Of those who were able to report on the frequency at which they met their supervisors, the most common responses were monthly, followed by weekly or quarterly (Table 15).

Table 15. Frequency of meetings of lead farmers with field staff members.

\begin{tabular}{|l|c|c|}
\hline \multicolumn{1}{|c|}{$\begin{array}{c}\text { Frequency of } \\
\text { meetings }\end{array}$} & Number of LFs who mentioned & Percentage \\
\hline Weekly & 27 & 17.6 \\
\hline Once in two weeks & 11 & 7.2 \\
\hline Monthly & 39 & 25.5 \\
\hline Quarterly & 26 & 17.0 \\
\hline Two times a year & 4 & 2.6 \\
\hline As needed & 33 & 21.6 \\
\hline Occasionally & 10 & 6.5 \\
\hline Never meets & 1 & 0.7 \\
\hline Others & 2 & 1.3 \\
\hline Total & $\mathbf{1 5 3}$ (missing $\mathbf{7})$ & $\mathbf{1 0 0 . 0}$ \\
\hline
\end{tabular}


In their interactions with field staff members, LFs used several means of communication. About half of the LFs (55percent) travelled to meet FS, and 70 percent used their personal cellphones to interact with FS as needed. Three LFs, living in areas without a mobile network, sent letters (through public transport) to their FS, or took advantage of occasional meetings to interact with their supervisors. The proportion of men LFs going to meet FS was very close to that of women LFs (55.2 percent versus 54.2 percent), but more men than women used their cellphones (74 percent versus 64.4 percent). Forty-four percent of men LFs said that they received visits from field staff members, but only 31.7 percent of female LFs reported receiving such visits. However, the difference between men and women LFs was not significant $(\mathrm{P}(\mathrm{t})=0.155)$. One LF reported using email for this purpose.

In their interaction with FS, LFs paid the costs of communication in 60 percent of the cases (Figure 17). Organizations and the farmer groups trained by LFs, contributed to communication expenses in 28 percent and 12 percent of the cases, respectively. These proportions are similar to those reported for communication costs between LFs and farmers, in Table 14. In both cases, the lead farmer most often incurs the costs.

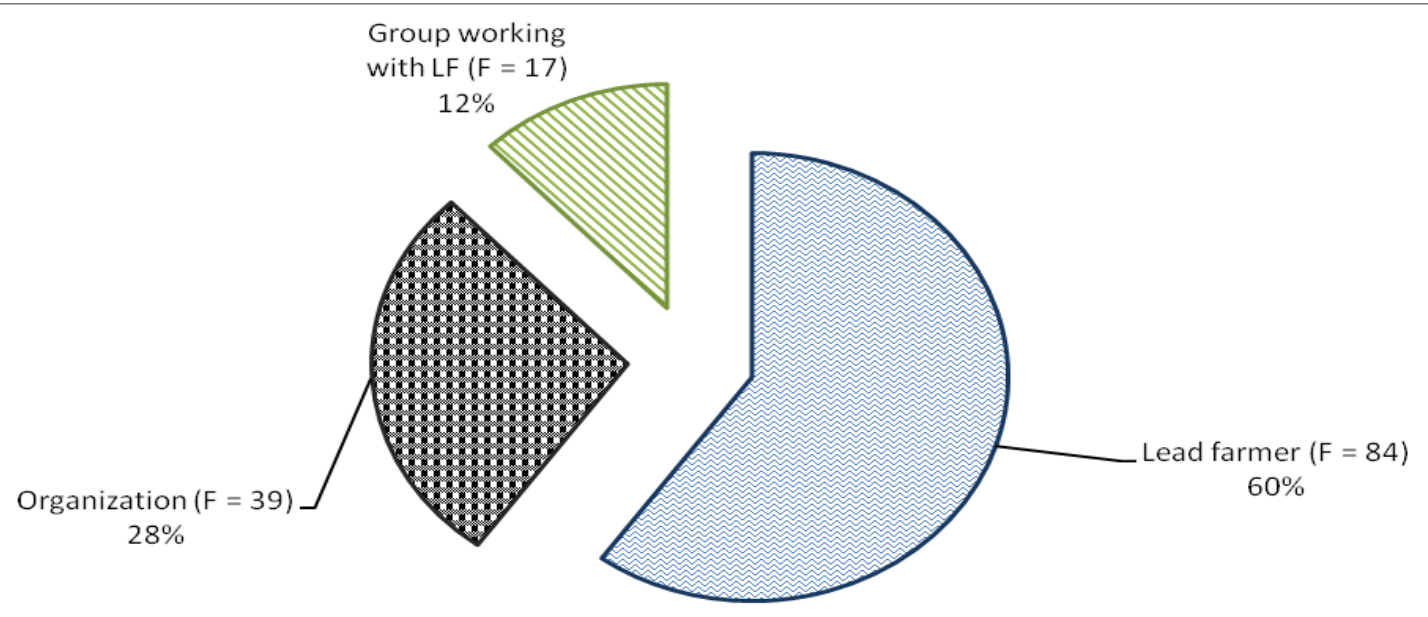

Figure 17. Payment for communication methods used by lead farmers to interact with field staff members.

About half (50.4 percent) of the LFs received training materials in support of their extension activities. More men (57.7 percent) received training materials than did women LFs (40.4 percent) with a marginal significant difference $(\mathrm{P}(\mathrm{t})=0.058)$. Among those who did receive materials, more than one-third (37.2 percent) received notebooks and considered this as training material. Indeed, after their initial trainings, LFs used their notes as a training tool. One LF translated his training notes into the local language to help his peers. Figure 18 also shows that most of the LFs still had the materials they had been given. 


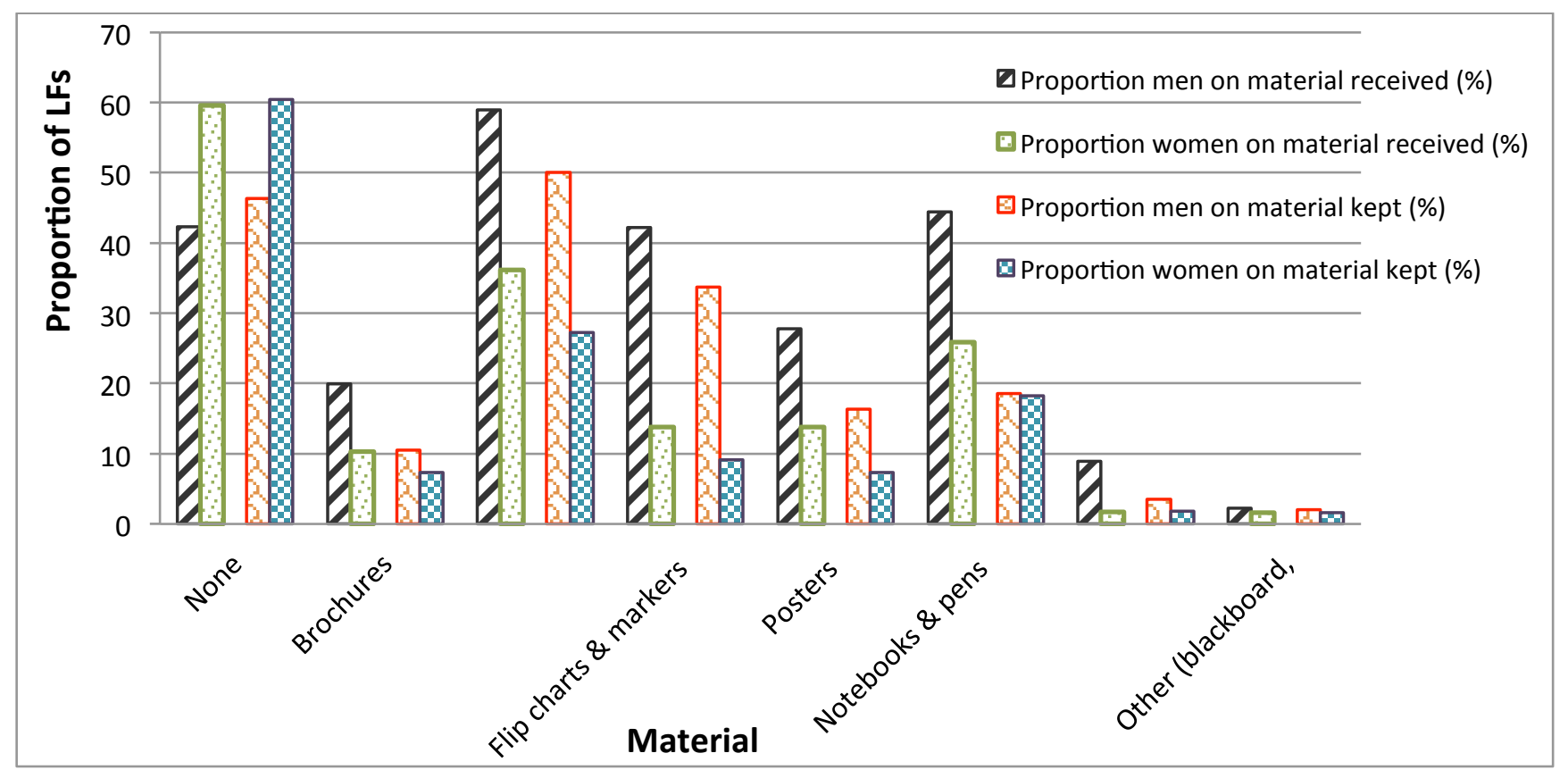

Note: Frequencies add up to over $\mathbf{1 0 0 \%}$ because some lead farmers gave multiple responses.

Figure 18. Training and support materials received or kept by lead farmers.

LFs took particular care of the training materials they received. Indeed, 70 percent of LFs still had the materials at the time of the interview, especially blackboards and bags, but also manuals and handbooks because these helped them in preparing for their training sessions. Some LFs declared that they gave away most of the training materials to farmers during training or follow-up visits.

Apart from training materials, LFs also received demonstration materials. Nursery or farm tools such as a machete, watering can, grafting knife, sprayer and measuring tape, as well as seeds/seedlings, were given to about one-third of LFs (Table 16). On most of the materials provided to LFs there was no difference in distribution by gender, except that the proportion of men LFs who received animal first-aid kits was greater than that of women LFs (12.8 percent versus 3.4 percent).

Many LFs received some kind of compensation or words of encouragement for continuing with their work. Sixty percent of the LFs received incentives such as verbal acknowledgment of their work and its usefulness. In addition, some farmer groups bought inputs for demonstration and the LFs benefited by being given the remainder. Moreover, some LFs received part of the harvest from demonstration plots. A good number of LFs, especially women, received public recognition or awards from field staff members or their group/community for their services (Figure 19). The giving of these awards often took place during the groups' general assemblies and were recognized with applause. Twelve LFs received salaries in variable amounts from the organization with which they worked. 
Table 16. Demonstration materials received by lead farmers to train farmers.

\begin{tabular}{|l|c|c|}
\hline Materials & Frequency & Proportion (\%) \\
\hline Nursery/farm tools & 49 & 34.5 \\
Seeds or seedlings & 45 & 32.4 \\
Fertilizers or compost & 22 & 15.4 \\
Protective clothing and/or gum boots & 14 & 10.1 \\
Animal first-aid kits & 13 & 9 \\
None & 75 & 56.4 \\
\end{tabular}

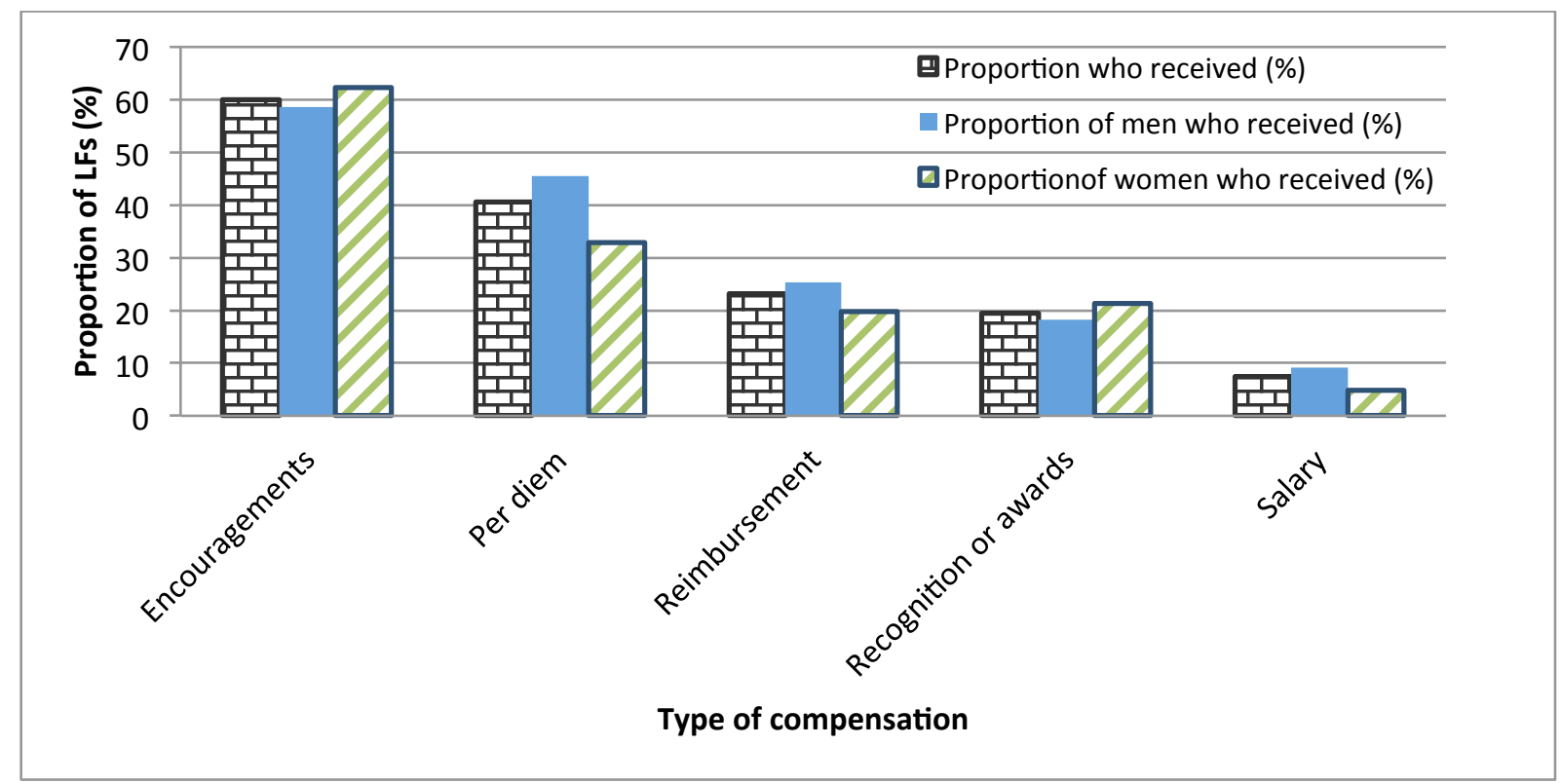

Note: Frequencies add up to over $\mathbf{1 0 0 \%}$ because some lead farmers gave multiple responses.

Figure 19. Types of compensation received by lead farmers.

LFs have benefited from the farmer-to-farmer approach. Indeed, even if the proportion that received a salary was very low, almost all LFs (95 percent) have been able to improve their income through application of new knowledge gained. There was no significant difference between men LFs and women LFs $(\mathrm{P}(\mathrm{t})=0.124)$ Indeed LFs reported that the quality of their produce had improved, allowing them to sell faster in the market, even in cases of abundant supply.

Furthermore, almost a quarter of LFs (23.7 percent) earned additional income from associated activities like selling seeds and seedlings. There was no significant difference between the two genders $(\mathrm{P}(\mathrm{t})=0.103)$. Others $(8.3$ percent $)$ were paid by their trainees or received gifts such as food, or benefited from free labour from trainees during training sessions on demonstration plots or in nurseries. Again, the difference between the two genders was not 
significant $(\mathrm{P}(\mathrm{t})=0.998)$. Two LFs were hired as consultants to train farmers or coordinate activities for other organizations. However, other LFs complained that spending time training others reduced the time that they could invest in their own farms.

Almost all LFs (94.4 percent) believed that the farmers they trained were also able to earn more income from their farming activities. Some farmers reported that their yields have doubled thanks to knowledge acquired from the training they have received. According to the lead farmers, many trainees have been able to improve their livelihoods and are now able to send their children to good schools and pay fees on time. In addition, women and children are better dressed than in the past. Some farmers have built houses, and some have bought new equipment such as solar lamps from their earnings. As farmers' yields have increased, expenses as well as losses have been reduced. Farmers earn more income, feed their families better and have better health. Some trainees, like the LFs, now have savings accounts. In some areas, trainees are now harvesting previously infertile lands, and some vulnerable populations, such as "Fulanis", who specialize in animal husbandry, are now producing and selling maize and other food crops, thanks to integrated cropping techniques promoted during trainings by LFs.

In cases where the farmers being trained have specific technical questions that LFs cannot answer, the LFs mainly call upon the FS who trained them for help. Some LFs look for solutions themselves (34.4 percent) by consulting other extension workers or other lead farmers, or look for information in relevant technical documents (Figure 20).

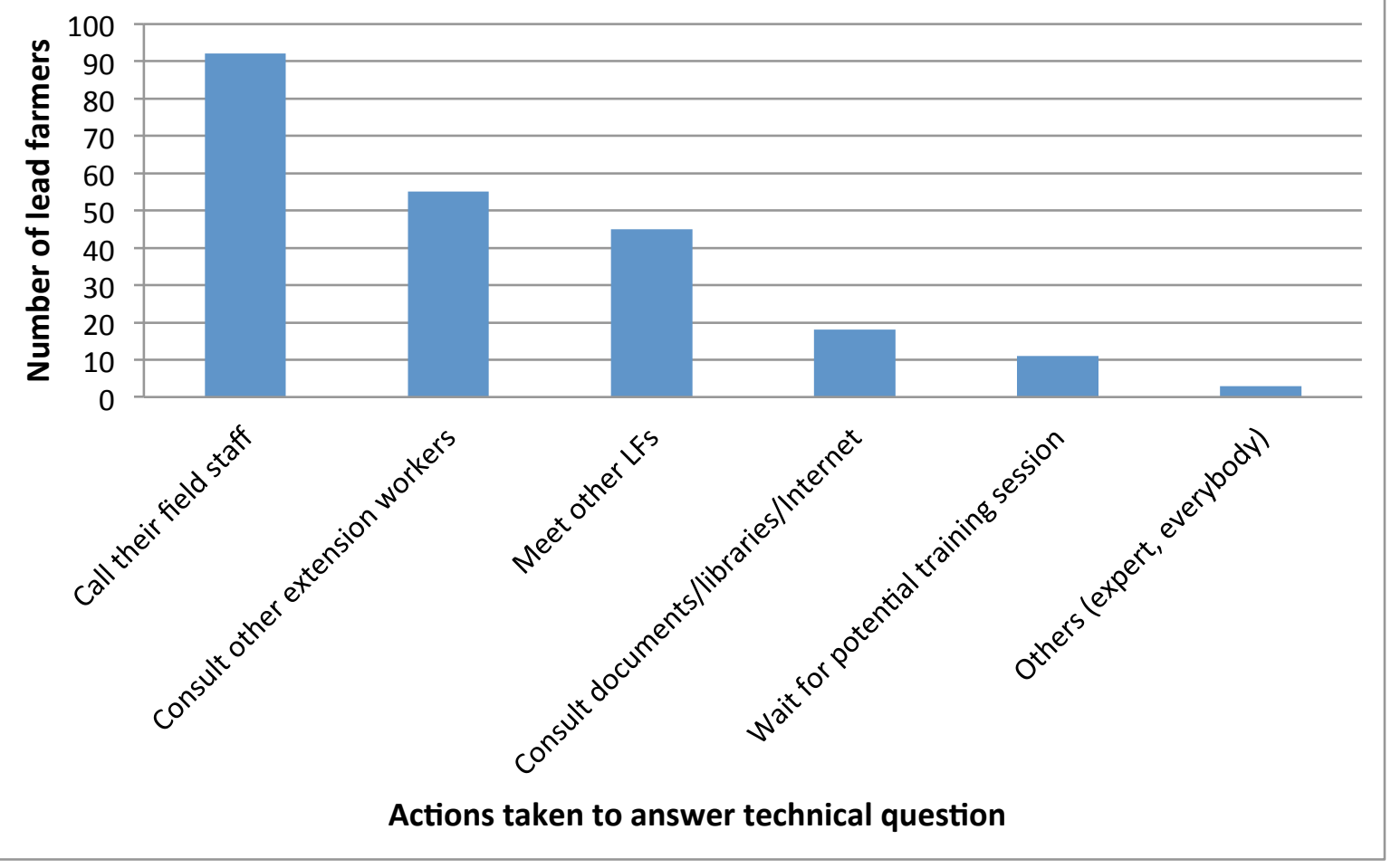

Figure 20. Actions that lead farmers took in case of technical question asked by trainees. 
About half of the lead farmers (57 percent) collaborated extensively with government extension workers (GEWs). Twenty-one percent of LFs had no contact with them, and the same proportion collaborated with them occasionally. The GEWs often shared information or brainstormed with LFs and often met in training sessions. One LF reported that he followed a yearlong training program together with a GEW who took all the modules as well. But there were also reports of conflicts. One LF noted that the local GEW viewed her as a competitor because her experience and competencies often made her messages more accepted by farmers.

To improve on their activities, LFs often met among themselves. Over half of the LFs (57 percent) had a chance to meet with other LFs at least once a month. Some also met occasionally, especially during training or planning sessions, or when one of them requested a meeting (Figure 21). Indeed, most LFs wanted to perform better and to be more useful in their area and therefore preferred regular interactions with fellow LFs.

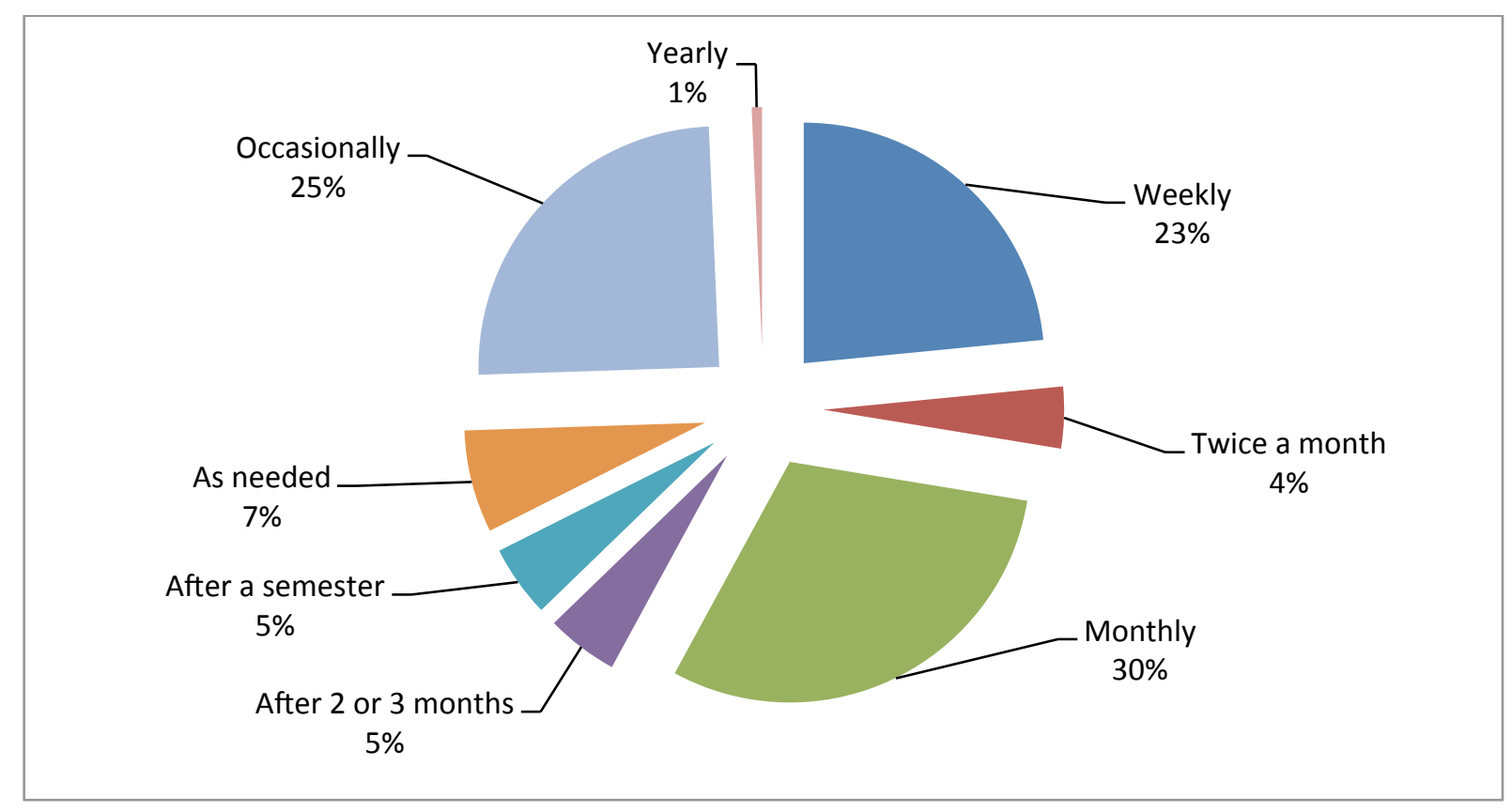

Figure 21. Frequency of meetings among lead farmers.

On average, LFs had met with an average of seven to eight other LFs (min=1, max=60). However, half of the LFs were in regular contact with fewer than five other LFs (Table 17). For those who were in contact with more than 10 other LFs, most of the other LFs were not from the same area. 
Table 17. Number of LFs that another LF had a chance to meet.

\begin{tabular}{|l|c|c|}
\hline Number of LFs met & Frequency & Proportion (\%) \\
\hline 1 to 5 & 79 & 54.9 \\
6 to 10 & 32 & 22.2 \\
11 to 15 & 23 & 16.0 \\
16 to 20 & 4 & 2.8 \\
21 to 25 & 1 & 0.7 \\
26 to 30 & 3 & 3.1 \\
31 and above & 2 & 1.4 \\
Missing & 16 & - \\
\hline Total & $\mathbf{1 6 0}$ & $\mathbf{1 0 0}$ \\
\hline
\end{tabular}

When they met, LFs mostly discussed the challenges related to their training activities (Figure 22). Meetings with other LFs also allowed them to exchange experiences, evaluate and plan their activities. In addition to discussing the farming activities of their trainees, LFs also discussed their own farming activities to look for ways to improve production. They said that when their meetings are organized or supervised by an organization, they concentrated more on their training function and discussed activity plans, follow-up, challenges and information for reporting. In meetings without external intervention, LFs focused mainly on their personal farming activities. Two respondents suggested that LFs would benefit more from the farmerto-farmer approach if they assembled into unions around specific activities or value chains.

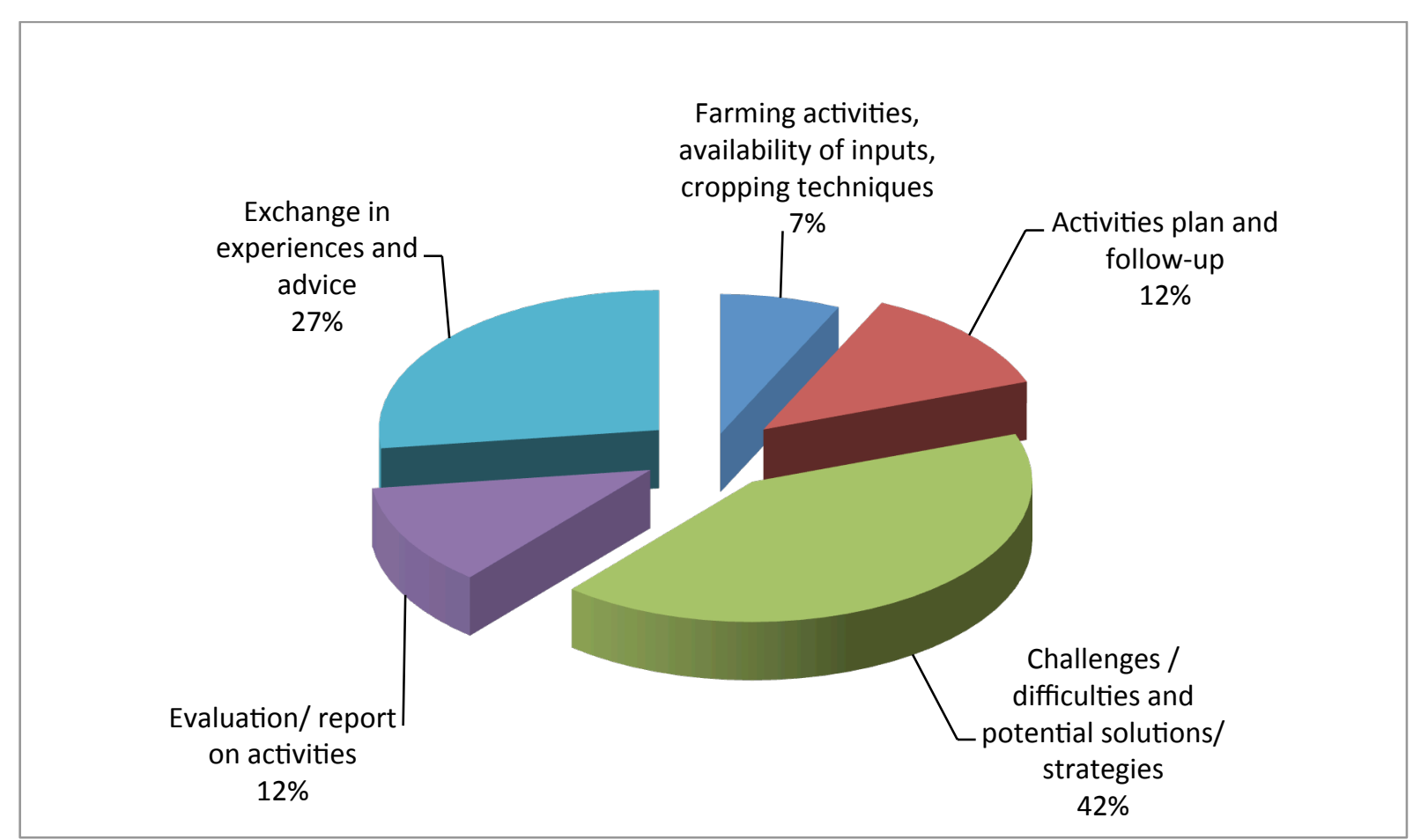

Figure 22. Main topics discussed by lead farmers during their meetings. 


\section{Lead farmers' performance assessment}

Since they started their work, each LF had trained on average 231 farmers ( $\min =2$ and $\max$ $=3600$, median =73). About half of the LFs, however, had trained fewer than 100 farmers since they took up this responsibility. In the year before the interview, each LF had trained 58 farmers $(\min =0$ and $\max =1275$, median $=17)$. Men LFs trained on average 63.3 farmers and women LFs trained 49.6 farmers during that period, but there was no significant difference between genders $(\mathrm{P}(\mathrm{t})=0.562)$.

We asked LFs the gender of their trainees during the past year. The average proportion of female trainees was 53.7 percent $(\min =0, \max =100$, median $=57)$. There was a significant difference $(\mathrm{P}(\mathrm{t})=0.001)$ in proportion of female trainees between men LFs $(41.1 \%$; $\min =0$, $\max =100$, median $=40)$ and women LFs $(74.8 \% ; \min =0, \max =100$, median $=83)$ ).

Furthermore, in the year before the survey, 16 percent of LFs trained only women. This was mostly the case with female LFs who worked with women's groups, either existing women's groups or groups that they formed made up of only women farmers.

Over the 12 months preceding the interview, some LFs (11 percent) did not train any farmers (Table 18). These LFs said that they did not receive any new training during that period so they did not train more farmers.

Table 18. Number of farmers trained by lead farmers.

\begin{tabular}{|l|c|c|c|c|}
\hline \multirow{2}{*}{ Number trained } & \multicolumn{2}{|c|}{ Since started } & \multicolumn{2}{c|}{ Over past 12 months } \\
\cline { 2 - 5 } & Frequency & Proportion (\%) & Frequency & Proportion (\%) \\
\hline 0 & 0 & 0.0 & 17 & 10.9 \\
1 to 50 & 64 & 41.5 & 100 & 64.1 \\
51 to 100 & 22 & 14.2 & 20 & 12.8 \\
101 to 150 & 14 & 9.1 & 8 & 5.1 \\
151 to 200 & 18 & 11.7 & 2 & 1.3 \\
201 to 250 & 6 & 3.9 & 2 & 1.3 \\
251 to 300 & 6 & 3.9 & 2 & 1.3 \\
301 and above & 24 & 15.6 & 5 & 3.2 \\
Missing & 6 & - & 4 & - \\
\hline Total & $\mathbf{1 6 0}$ & & $\mathbf{1 6 0}$ & $\mathbf{1 0 0}$ \\
\hline
\end{tabular}

Nearly all LFs (98.1 percent) mentioned at least one topic that they had successfully passed on to their trainees. However, 86.9 percent of LFs also mentioned that some topics were not successfully transmitted. The respondents' perceptions of relatively successful and unsuccessful trainings (Table 19) suggest that they appear to have been most successful in general agriculture, crop production and income-generating activities, but somewhat less successful in animal production and agroforestry. The problem with less successful topics could have been the lead farmers' ability to conduct a training on a particular topic, or their 
comprehension of the topic. Concerning agroforestry, 65.9 percent of LFs were of the opinion that they had not mastered the topic well and had difficulties with 71.4 percent of the agroforestry sub-topics. However, 29.5 percent of LFs said they had successfully passed on to their trainees all agroforestry innovations they were trained on. Many lead farmers said they needed more training in agroforestry. In agroforestry, the number of sub-topics that respondents taught to their peers was the same as the number that they had been trained on.

Table 19. Most successful and least successful topics taught by lead farmers.

\begin{tabular}{|c|c|c|c|c|c|c|c|c|}
\hline \multirow[b]{2}{*}{ Topics } & \multicolumn{4}{|c|}{ Topics most successfully taught by LFs } & \multicolumn{4}{|c|}{ Topics least successfully taught by LFs } \\
\hline & Items & $\begin{array}{l}\text { Numb } \\
\text { er of } \\
\text { LFs }\end{array}$ & $\begin{array}{l}\% \text { of } \\
\text { LFs } \\
\text { from } \\
\text { those } \\
\text { who } \\
\text { trained }\end{array}$ & $\begin{array}{l}\text { No. of } \\
\text { items } \\
\text { in } \\
\text { topic }\end{array}$ & Items & $\begin{array}{c}\text { No. of } \\
\text { LFs }\end{array}$ & $\begin{array}{c}\text { \% of } \\
\text { LFs } \\
\text { from } \\
\text { those } \\
\text { trained }\end{array}$ & $\begin{array}{l}\text { Number } \\
\text { of items }\end{array}$ \\
\hline $\begin{array}{l}\text { Crop } \\
\text { producti } \\
\text { on/ } \\
\text { farming }\end{array}$ & $\begin{array}{l}\text { Beans, maize, } \\
\text { plantain, cassava, } \\
\text { cocoa, coffee, } \\
\text { potatoes, yam, } \\
\text { seed production, } \\
\text { plantain }\end{array}$ & 82 & 66.7 & 14 & $\begin{array}{l}\text { Gardening; beans, } \\
\text { cassava, cocoa, } \\
\text { coffee, groundnut, } \\
\text { maize, pineapple, } \\
\text { Irish potatoes, yam } \\
\text { farming; } \\
\text { mushroom, seed } \\
\text { production plantain }\end{array}$ & 47 & 38.2 & 16 \\
\hline $\begin{array}{l}\text { Agricult } \\
\text { ure }\end{array}$ & $\begin{array}{l}\text { Use of compost, } \\
\text { crop protection, } \\
\text { farm management, } \\
\text { farming } \\
\text { techniques, } \\
\text { fertilizer } \\
\text { application, land } \\
\text { preparation }\end{array}$ & 22 & 37.9 & 8 & $\begin{array}{l}\text { Chemical/fertilizer } \\
\text { application, farm } \\
\text { management and } \\
\text { record keeping, } \\
\text { farming techniques, } \\
\text { intercropping, } \\
\text { contour farming, } \\
\text { soil conservation }\end{array}$ & 18 & 31.0 & 8 \\
\hline $\begin{array}{l}\text { Agrofor } \\
\text { estry }\end{array}$ & $\begin{array}{l}\text { Domestication } \\
\text { technique: } \\
\text { marcotting, } \\
\text { grafting, } \\
\text { propagation from } \\
\text { cuttings; nursery } \\
\text { development, } \\
\text { pruning, tree } \\
\text { planting } \\
\end{array}$ & 13 & 29.5 & 7 & $\begin{array}{l}\text { Domestication } \\
\text { technique: grafting, } \\
\text { marcotting, cutting, } \\
\text { tree planting; } \\
\text { nursery } \\
\text { installation/manage } \\
\text { ment }\end{array}$ & 29 & 65.9 & 5 \\
\hline $\begin{array}{l}\text { Animal } \\
\text { husband } \\
\text { ry }\end{array}$ & $\begin{array}{l}\text { Animal } \\
\text { management, } \\
\text { piggery, poultry, } \\
\text { fish farming, food } \\
\text { processing, rabbit } \\
\text { husbandry }\end{array}$ & 12 & 27.3 & 8 & $\begin{array}{l}\text { Chicken } \\
\text { production, dairy, } \\
\text { piggery, poultry, } \\
\text { grasscutter (a local } \\
\text { rodent raised for } \\
\text { meat) }\end{array}$ & 17 & 38.6 & 5 \\
\hline
\end{tabular}




\begin{tabular}{|l|l|l|l|l|l|c|c|c|}
\hline & \multicolumn{3}{|l|}{ Topics most successfully taught by LFs } & \multicolumn{3}{l|}{ Topics least successfully taught by LFs } \\
\hline Topics & Items & $\begin{array}{l}\text { Numb } \\
\text { er of } \\
\text { LFs }\end{array}$ & $\begin{array}{l}\text { LF } \\
\text { LFs } \\
\text { from } \\
\text { those } \\
\text { who } \\
\text { trained }\end{array}$ & $\begin{array}{l}\text { No. of } \\
\text { items } \\
\text { in } \\
\text { topic }\end{array}$ & Items & $\begin{array}{l}\text { No. of } \\
\text { LFs }\end{array}$ & $\begin{array}{c}\text { \% of } \\
\text { LFs } \\
\text { from } \\
\text { those } \\
\text { trained }\end{array}$ & $\begin{array}{l}\text { Number } \\
\text { of items }\end{array}$ \\
\hline $\begin{array}{l}\text { Income- } \\
\text { generati } \\
\text { ng } \\
\text { activitie } \\
\text { s }\end{array}$ & $\begin{array}{l}\text { Cacao drying } \\
\text { process, cassava, } \\
\text { soybeans, shea } \\
\text { processing, } \\
\text { marketing } \\
\text { techniques }\end{array}$ & 11 & 25.0 & 5 & $\begin{array}{l}\text { Milk processing, } \\
\text { soap processing, } \\
\text { market organization }\end{array}$ & 6 & 13.6 & 3 \\
\hline
\end{tabular}

In crop production, more than half of the LFs mentioned subtopics that they felt they had successfully communicated in training sessions. Nevertheless, 30 percent of LFs had difficulties with a number of crop production subtopics, such as gardening, yam cultivation and plantain seed production. Despite the low level of competence declared by some LFs, respondents believed that they had successfully trained their peers on average in 14 crop production subtopics, representing 87.5 percent of the total number of topics on which LFs themselves were trained.

Following the training sessions, 61 percent of LFs modified some of the recommendations that they had been taught. These modifications were often their own innovation. Among LFs who modified their training content, 73 percent said that their modifications responded to local field conditions and the types of problems farmers faced. Some LFs were specific about technical adaptations that they had made, such as:

Plant maize at $40 \mathrm{~cm} \times 80 \mathrm{~cm}$ spacing rather than the recommended $50 \mathrm{~cm} \times 100 \mathrm{~cm}$.

Plant maize at $50 \mathrm{~cm}$ intervals rather than $40 \mathrm{~cm}$.

Plant maize in two rows as opposed to one, but on ridges.

Apply compost in the row for maize, instead of putting in it the seed hole.

Dry maize for one or two days in the sun before putting it in the drier, instead of putting it in directly after harvesting.

Use cooking oil and cypress tree branches to protect beans instead of using chemicals.

Destroy/cut plantain at six months of age to have more shoots, rather than using the "plants issued from stem fragments" (PIF) technique.

Plough partially (especially around the seed hole) and not the whole field in preparation for planting Irish potatoes.

Mix different fertilizers and apply at one time instead of applying one after another.

Spraying after three weeks and applying fertilizers after two days rather than applying just fertilizer after three weeks.

Use black plastic to produce mushrooms rather using a dark room.

Space cocoa trees at $2.5 \mathrm{~m}$ instead of $2 \mathrm{~m}$. 
Covering some branches with soil for layering, where possible, in addition to marcotting on the tree.

Planting pineapple and "gkui" on contour lines for erosion control in addition to using trees.

Making own poultry food composition instead of buying feed.

Using corn cobs to feed animals instead of using only pasture.

Reduce the sleeping and milking space during stable construction.

Reduce the rooms' dimensions in the stable.

Reduce the number of top bars in constructing beehives.

Use bamboo instead of wood planks to construct hives.

Install hives higher than the recommended $50 \mathrm{~cm}$ above the ground.

Put hive's entrance up and not down.

According to 75 percent of lead farmers, their organizations encouraged them to innovate.

Indeed, some were congratulated and some received incentives (Figure 23), but only when the innovation did not lead to failures.

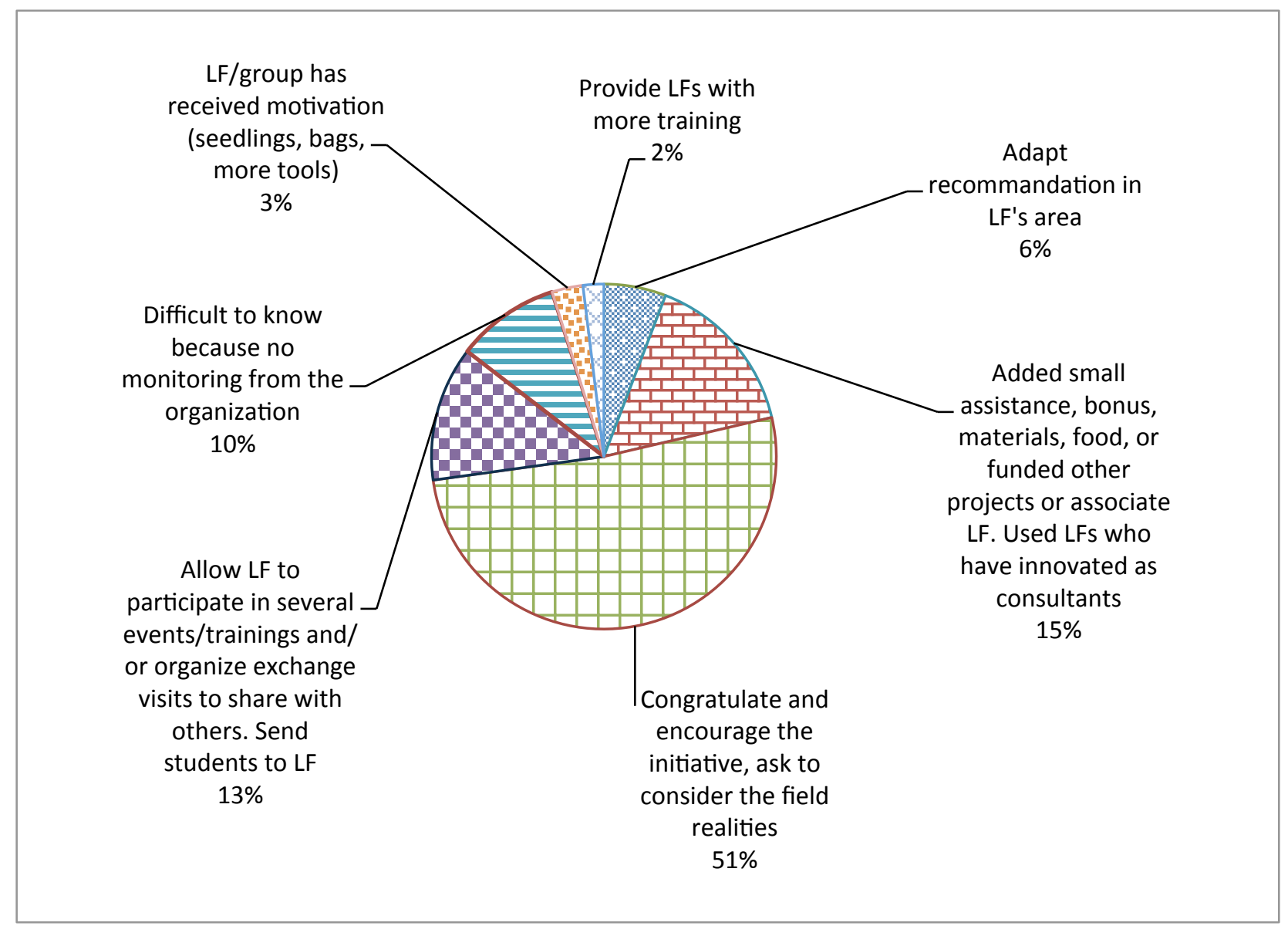

Figure 23. Types of incentives given by organizations to LFs who successfully innovated. 


\section{Motivations and challenges of lead farmers}

LFs mentioned many reasons that motivated them to become LFs. More than four-fifths of LFs mentioned altruism and the potential to generate income as the main motivations that brought them to the position of LF. In addition, 63 percent of LFs said that they were motivated by the desire to gain early access to new technologies (Figure 24). For all of the motivations mentioned, there was no significant difference between men and women LFs.

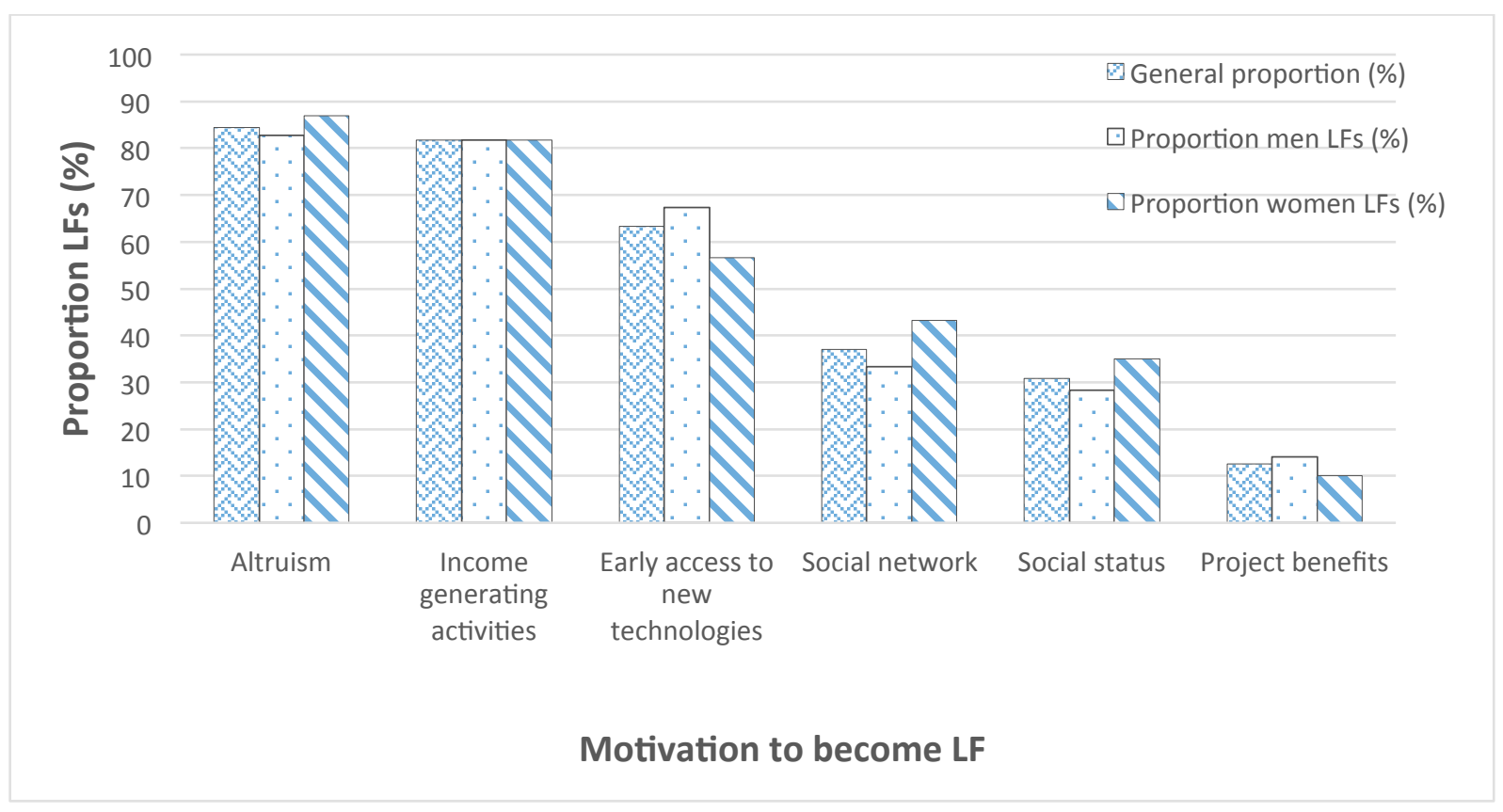

Figure 24. Motivations mentioned by LFs to become LFs.

When LFs were asked to rank these motivations (Table 20), a majority (71.5 percent) of LFs ranked "income-generating activity" as the first or second most important motivation in becoming a lead farmer. Some LFs stated that if they were not financially better off, their children would not imitate them and other farmers might not take their advice seriously. "Altruism" was also very important, with 69.1 percent ranking it as their first or second motivation. "Early access to new technologies" was the third highest motivation to become a LF (mentioned by 63.9 percent of LFs as first or second motivation). Less important motivations mentioned by LFs were social networking (meeting many people and making new contacts), project benefits (getting equipment or inputs) and improving one's social status.

There were some differences in LF's motivations to remain LFs after serving for some time. Altruism was the highest ranked motivation, ranked in the first or second highest category by 78.8 percent of LFs. Income-generating activities and early access to technology were second and third, respectively, having declined slightly in rank from their position as motivations to become a LF. The importance of social status increased somewhat, from 25.5 percent mentioning it as a first or second most important motivation to become a lead farmer to 41.2 percent ranking it as a reason to remain a lead farmer, perhaps because some farmers 
recognized that being a LF did enhance their social status. In summary, lead farmers in the beginning want to get early access to new technologies to generate more income from their personal farms, and subsequently help other farmers via trainings. But later on, their main motivations shift toward helping their peers, followed by generating more income thanks to the early access to new technologies. Box 1 presents an example of farmers' motivations to be volunteer farmer trainers in a farmers' organization in the North-West Region of Cameroon.

Table 20. Farmers' ranking of their motivations to become and remain LFs.

\begin{tabular}{|c|c|c|c|c|c|c|c|c|c|c|c|c|}
\hline \multirow[t]{2}{*}{$\begin{array}{l}\text { Motiv } \\
\text { ation }\end{array}$} & \multicolumn{6}{|c|}{$\begin{array}{l}\text { Proportion of LFs with motivation to } \\
\text { become LF }\end{array}$} & \multicolumn{6}{|c|}{$\begin{array}{l}\text { Proportion of LFs with motivation to } \\
\text { remain in the function }\end{array}$} \\
\hline & 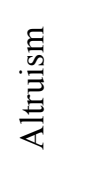 & 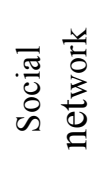 & 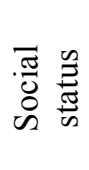 & 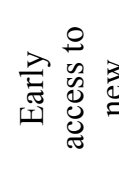 & 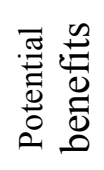 & 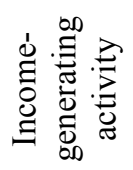 & $\stackrel{\Xi}{\Xi}$ & \begin{tabular}{ll}
$\bar{\pi}$ & $\frac{y}{0}$ \\
$\overline{0}$ & $\vdots$ \\
0 & 0 \\
\hdashline
\end{tabular} & 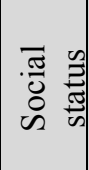 & 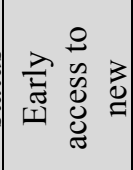 & 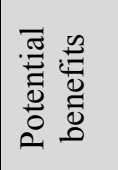 & 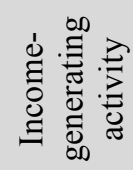 \\
\hline First & 33.8 & 9.1 & 13.7 & 44.1 & 14.7 & 36.5 & 46.5 & 9.7 & \begin{tabular}{|l|}
19.0 \\
\end{tabular} & 35.2 & 6.3 & 35.3 \\
\hline Second & 35.3 & 24.7 & 11.8 & 19.8 & 14.7 & 35.0 & 32.3 & 22.2 & \begin{tabular}{|l|}
22.2 \\
\end{tabular} & 20.9 & 21.9 & 32.3 \\
\hline Third & 20.3 & 19.5 & 13.7 & 22.5 & 23.5 & 17.5 & 11.8 & 25.0 & \begin{tabular}{|l|}
14.3 \\
\end{tabular} & 25.3 & 21.9 & 21.1 \\
\hline Fourth & 8.3 & 22.1 & 23.5 & 10.8 & 11.8 & 7.3 & 6.3 & 25.0 & \begin{tabular}{|l|}
9.5 \\
\end{tabular} & 12.1 & 12.5 & 9.0 \\
\hline Fifth & 1.5 & 23.4 & 21.6 & 2.7 & 8.8 & 1.5 & 1.6 & 15.3 & \begin{tabular}{|l|}
19.0 \\
\end{tabular} & 4.4 & 18.8 & 1.5 \\
\hline Sixth & 0.8 & 1.3 & 15.7 & 0.0 & 26.5 & 2.2 & 1.6 & 2.8 & \begin{tabular}{|l|}
15.9 \\
\end{tabular} & 2.2 & 18.8 & 0.8 \\
\hline
\end{tabular}

Box 1. Incentives for becoming and remaining a local animator with a farmers' organization (FO) in North-West Region, Cameroon.

The FO has 3,000 farmer members. Its mission is to improve crop and livestock production among its members. It also gives considerable attention to gender and marketing. Staff members work with $70 \mathrm{LFs}$, called "local animators". The FO finds that several types of incentives are important for motivating its local animators. Social status and social networking are important motivations for someone to become and remain an animator. An animator in Batibo has become a counselor in the traditional council, and being a local animator definitely helped him to gain this position. Others become church leaders after serving as local animators.

Some farmers also benefit from being local animators to find clients for their enterprises. One animator in Mfoya has pigs and trains other farmers in pig management. Being a LF helps him find clients to buy his piglets. Since 2007, he has increased the number of sows from two to five and sells 30 piglets every six months. His position as a local animator has also helped him to secure a leadership position in the FO and in another farmer association dealing with pigs.

The FO does not pay its local animators but sometimes allocates funds to the animators to assist them to train more farmers. For instance, one of the member unions situated in Bafut gives its animators 10,000 CFA (\$US 21; \$US 1 $=476 \mathrm{CFA}$ ) every six months. At the same time, the FO tries to encourage its animators to be less money-oriented in their service to the organization -- that is, not to expect payments from the FO for offering extension advice to fellow farmers. On the other hand, the FO encourages them to develop their businesses by building on extensionrelated activities, as the animator in Mfoya does by selling piglets. The concerned FO is also positive about the idea of farmers receiving payments from other farmers for extension services, though that has not yet started.

Every year, the FO has a contest for the best animator and gives a prize. The organization finds that the contest is an important encouragement for animators to improve their performance. 
LFs mentioned many benefits related to the F2F approach. The majority (60 percent) found the approach very useful for the development of local capacities, that is, strengthening farmers' capacities in agricultural knowledge and in training other farmers (Figure 25). Others found that the approach facilitated and increased adoption of the technologies/practices promoted, increased the number of farmers contacted (relative to numbers that would be reached if there were no LFs). About 38 percent commented that it increased the relevance of extension content by promoting feedback from farmers. Only a few LFs did not see any benefit from the farmer-to-farmer approach. Some LFs considered their role in extension to be important because they are flexible and consider field/local realities in assisting their peers, whereas government extension workers often work under programs that are not as flexible or adaptive. In addition, LFs also observed that farmers who witnessed changes in LFs' farms or demonstration plots are more open to innovations and have confidence in the LFs. In contrast, in some areas, LFs observed that farmers prefer a person from outside the community to train them. Significantly $(\mathrm{P}(\mathrm{t})<0.05)$ more men than women found the F2F approach helped in reducing the costs of extension services.

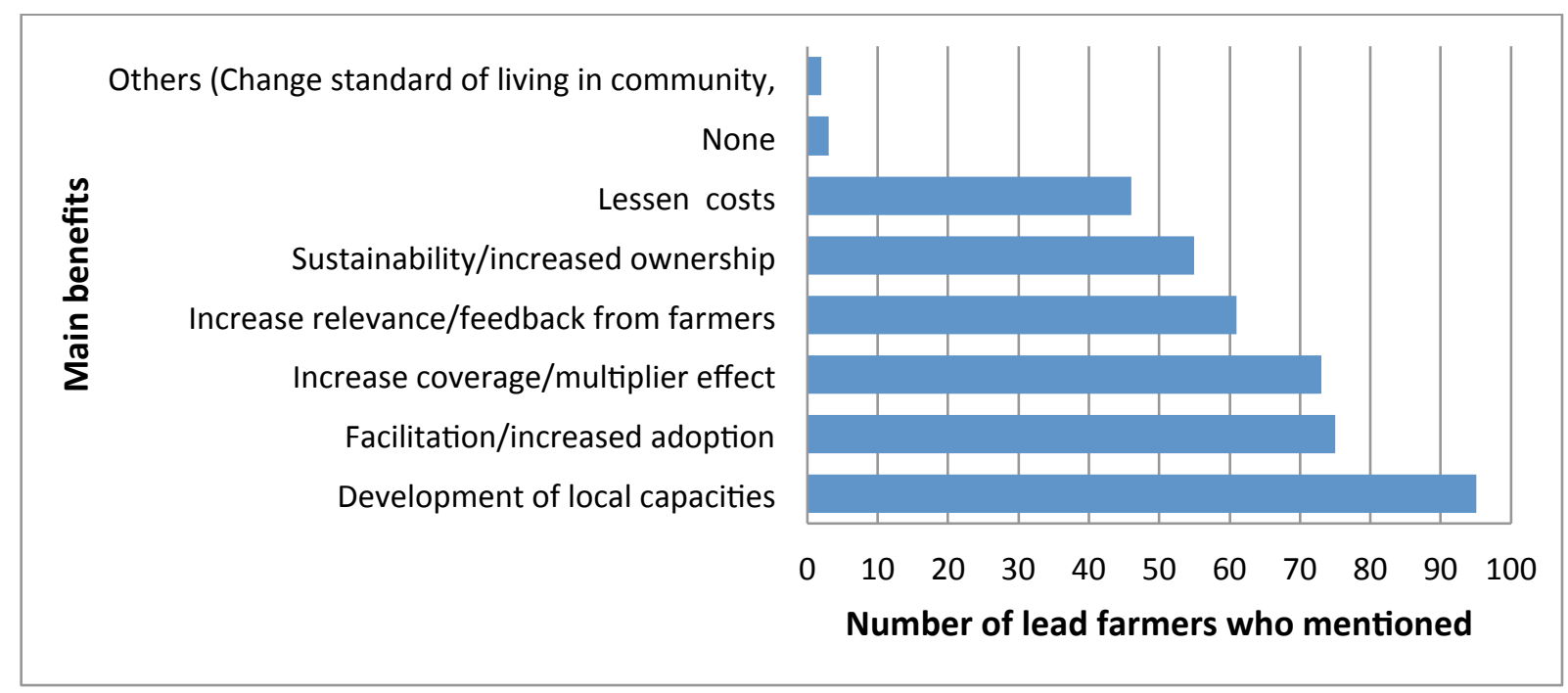

Figure 25. Main benefits of the farmer-to-farmer approach observed by lead farmers.

LFs also identified many challenges in their participation in F2F programs. More than twothirds of LFs reported budget limitations and insufficient transportation and communication support as their main difficulties. Many villages had difficulty accessing LFs, and farmers' expectations of LFs were often too high. High expectations were compounded by the fact that training and/or demonstration materials were often insufficient. Even though many LFs did not find it difficult to mobilize farmers, some had to face problems with farmers who asked for per-diem or expected to receive money or inputs from their trainers. Some LFs also experienced low adoption rates of the technologies they were promoting, especially technologies that required additional labour or took several years before benefits could be seen. In addition, some LFs had to deal either with conflicting messages or influence of some stakeholders like lazy farmers, or with resistance of government extension workers who saw 
them as competitors or did not acknowledge their efforts. Box 2 below illustrates one such situation faced by a LF.

Very few LFs mentioned any difficulty in reaching women farmers (Figure 26). Some LFs even declared that women farmers were more accessible than their male fellows. But, according to other LFs, women farmers were often negligent of their farms, and this obliged trainers to pay more attention to them.

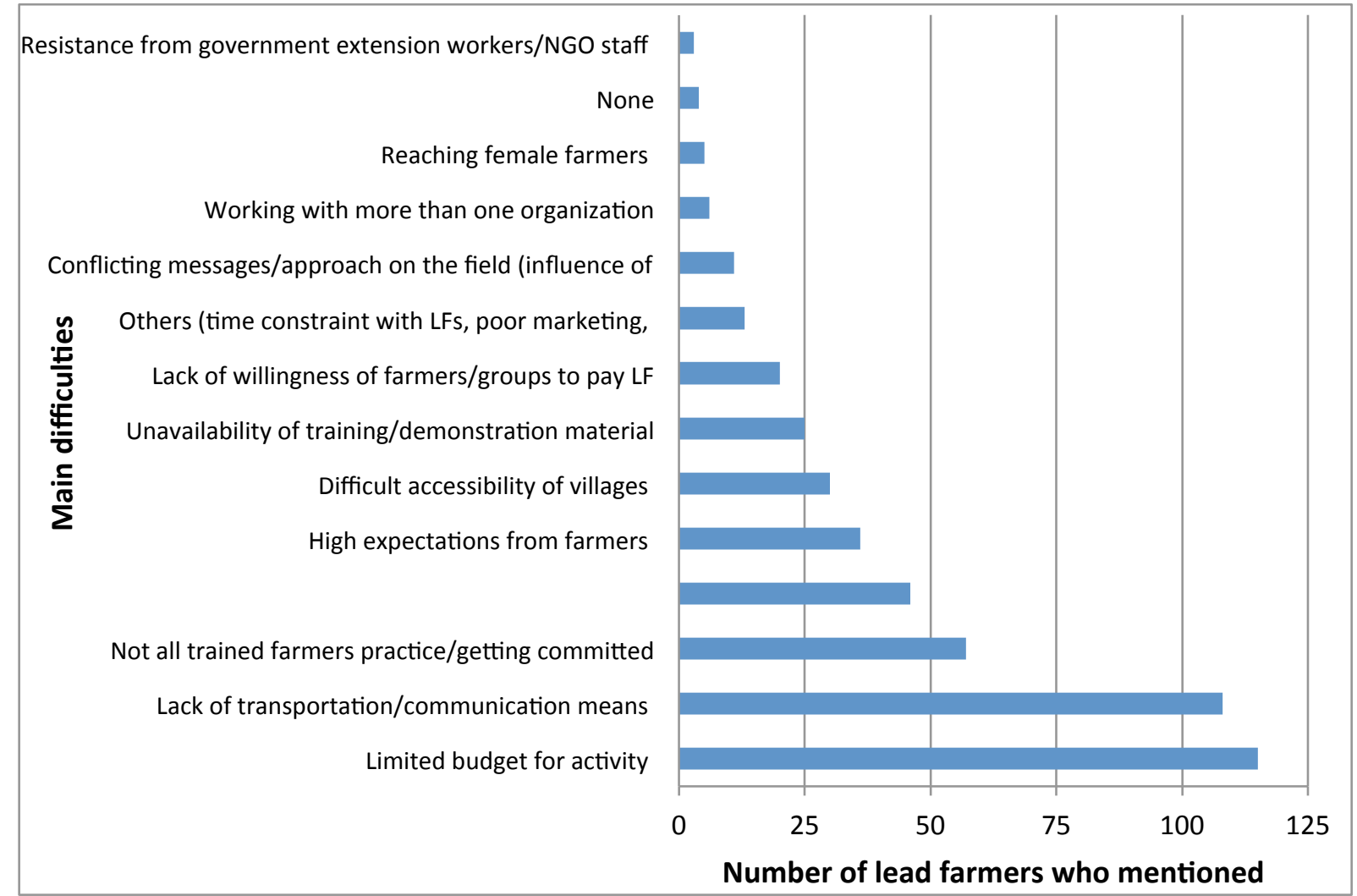

Figure 26. Main challenges faced by lead farmers. 


\section{Box 2: A conflict between a lead farmer and a government extension worker}

In the central region of Cameroon, a farmer organization's mission is to improve the socioeconomic conditions of its members, around 200 farmers. Its activities are based on crop farming, livestock, marketing and training of farmers.

At the beginning of each agricultural campaign, one of the 12 lead farmers (LFs) of the organization is designated to inform the government extension worker about their plans in order to improve their collaboration. One year ago, a conflict occurred between one LF of this organization and the extension worker. The concerned lead farmer reported: "When I was preparing the first campaign of this year, I informed the agricultural delegate, and he agreed with my plans. So, I went to the extension worker just to inform him. As he was absent, I met his assistant, and he refused to receive me because I was a farmer trainer. He said: "I don't know what a farmer trainer is". Though I insisted, trying to explain, as he was not aware of my duties, he did not receive me."

This story suggests that there is need to involve government extension workers from the start of a F2F extension program and to get official recognition for LFs. In this case, if the LF had, for example, a certificate presenting his credentials as a LF, he could have shown it to the extension worker and perhaps avoided the conflict.

Over the previous 12 months, LFs reported incurring on average 32,893 CFA francs ( $\min =0$, $\max =600,000$, median $=4500)$ in operational costs. The average amount reportedly spent by men LFs (40,648 CFA francs) was greater than that by women LFs (17,695 CFA francs). But the difference was not significant $(\mathrm{P}(\mathrm{t})=0.144)$, because of the high degree of variation in the amounts that both men and women spent.

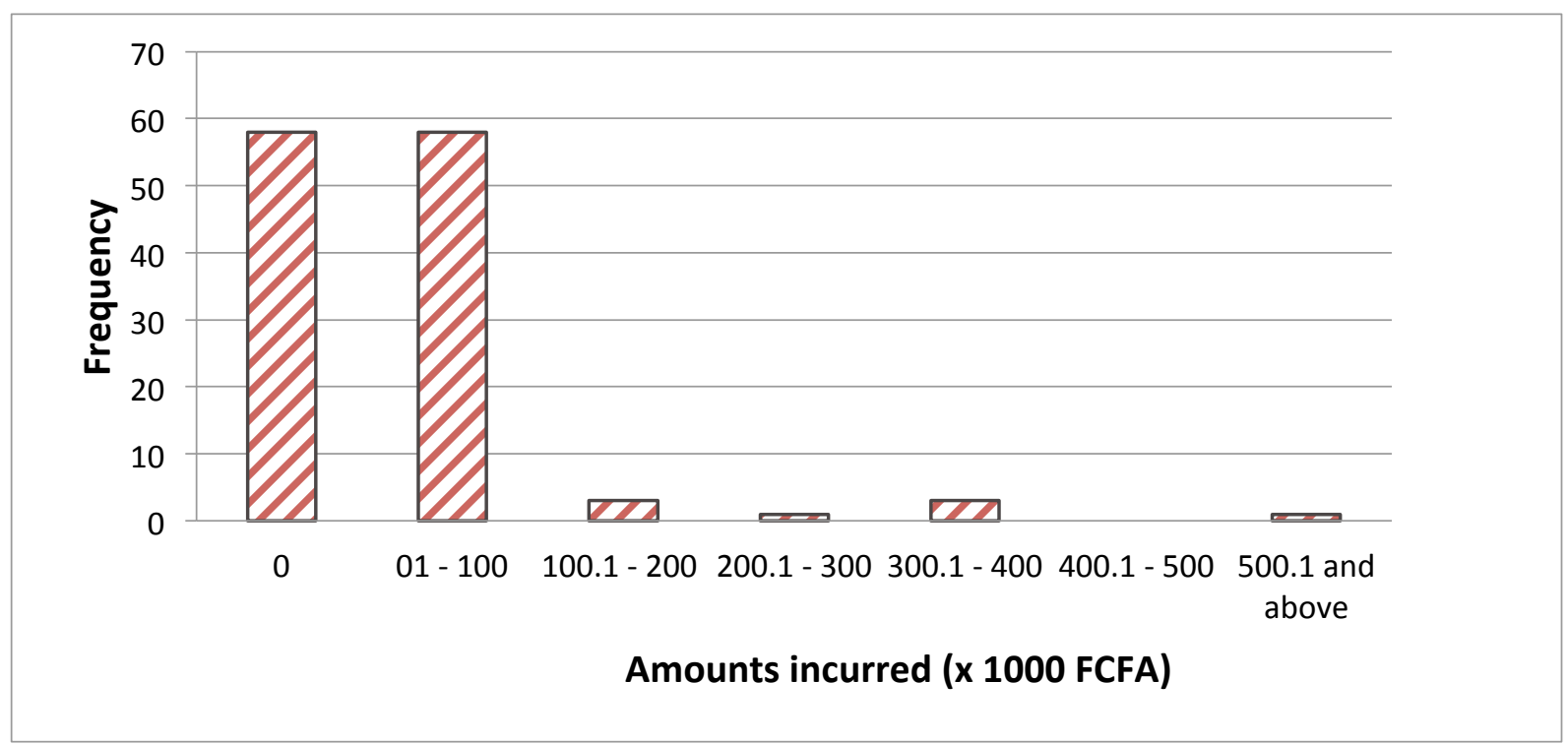

Figure 27. Costs incurred by lead farmers in training farmers over the previous 12 months.

Transportation and cellphone airtime were the main expenses reported, and each was mentioned by at least a quarter of lead farmers (Figure 28). In addition to demonstration materials that some LFs provided to their trainees, some LFs often felt obliged to share food and/or drinks with their trainees after training sessions. 


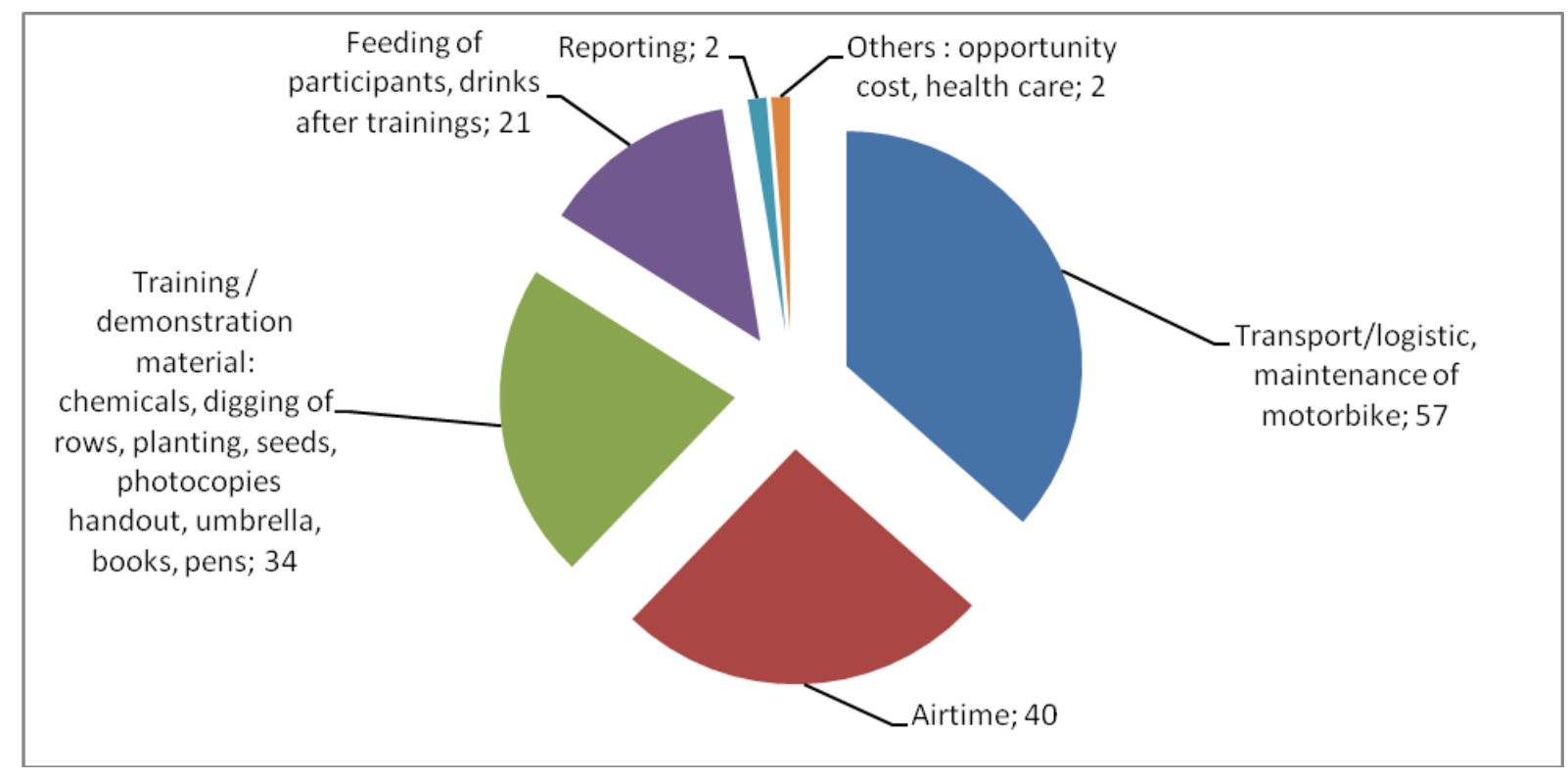

Figure 28. Main domains of expenditures incurred by lead farmers during the previous 12 months.

LFs made many suggestions to improve the F2F approach and to make it benefit more farmers. Although some respondents did not have any suggestions, most LFs (81 percent) mentioned issues related to the support that would enable them to become more effective LFs, such as provision of training and demonstration material, transportation and communication facilities. They also stated a need for training more LFs and opportunities to refresh the knowledge of those who were already working as LFs (Figure 29). The main technical areas where LFs cited the need for further capacity development were communication skills, modern agricultural practices and activities' planning. To develop their capacities, around one-third of LFs (31 percent) suggested that FS working with them should "scrutinize their main training needs," intensify supervision/follow-up, increase the number of exchange visits among LFs and farmers, add training on more new technologies, and provide LFs with more technical support/assistance. According to LFs, the creation of resource centres or suitable training centres and accessible demonstration plots for all crops is very important. In addition, some LFs mentioned the need to intensify awareness raising and the promotion of innovations with farmers. For instance, sensitize farmers, especially youths, to recognize the role of LFs, to attend training sessions and meetings, and to join existing groups or form new groups. LFs should also be made aware of the importance of records and encouraged to keep records and write reports. Authorities, as well as projects/organizations, should be shown the importance of the F2F approach. 


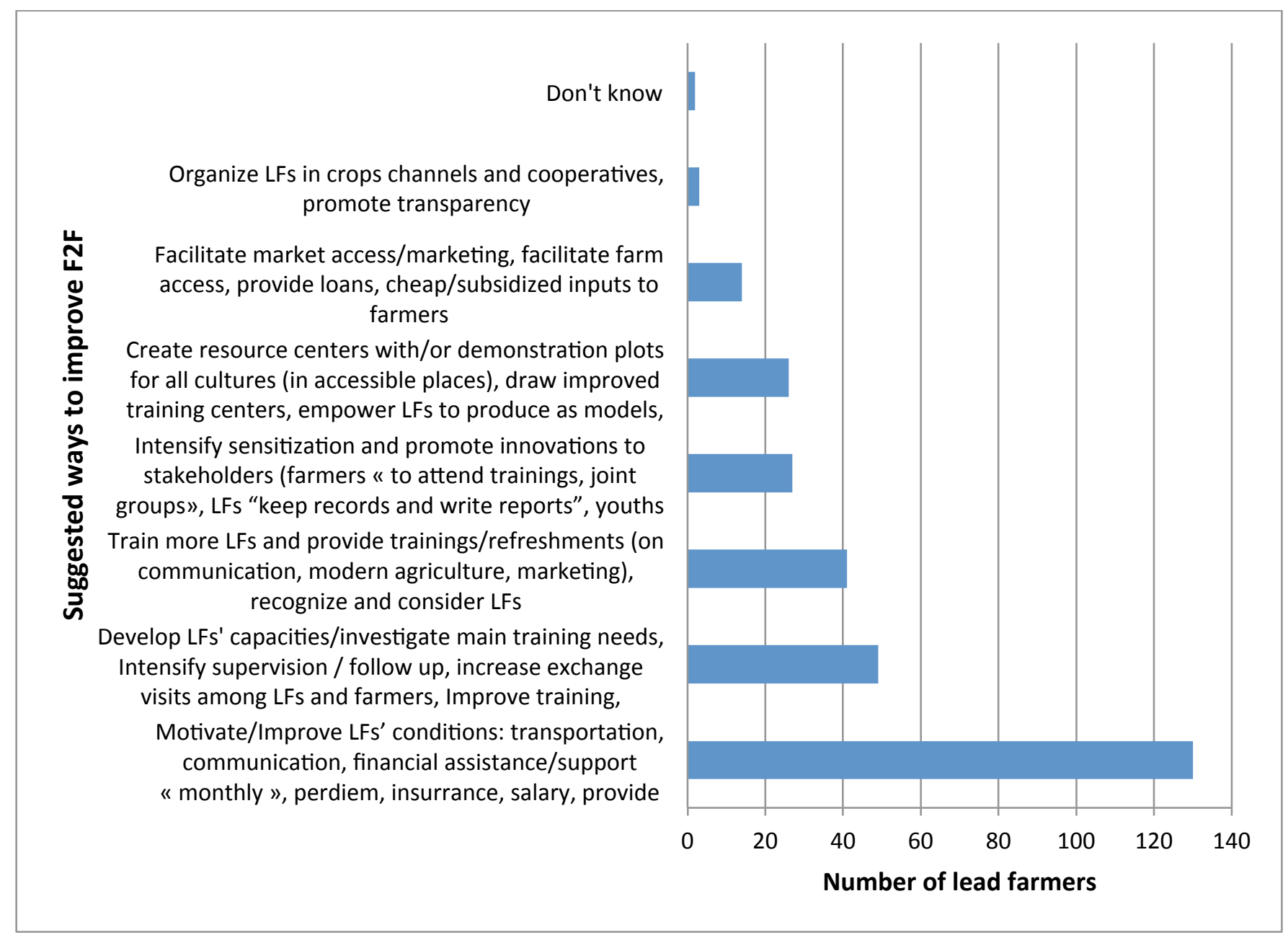

Figure 29. Suggestions by LFs to make farmer-to-farmer approach benefit more farmers.

LFs mentioned that they are too few and suggested that more LFs should be trained and those already serving should receive refresher courses in participatory/communication techniques and modern agriculture. LFs also felt that they should be better supported in their job - for instance, through provision of transportation, communication, salary or monthly financial assistance, insurance, training and demonstration material/inputs, certificates after trainings, awards. Despite these observations, about 94 percent of LFs stated that they would continue to train their fellow farmers even when organizations working with them leave or if the project ends. 


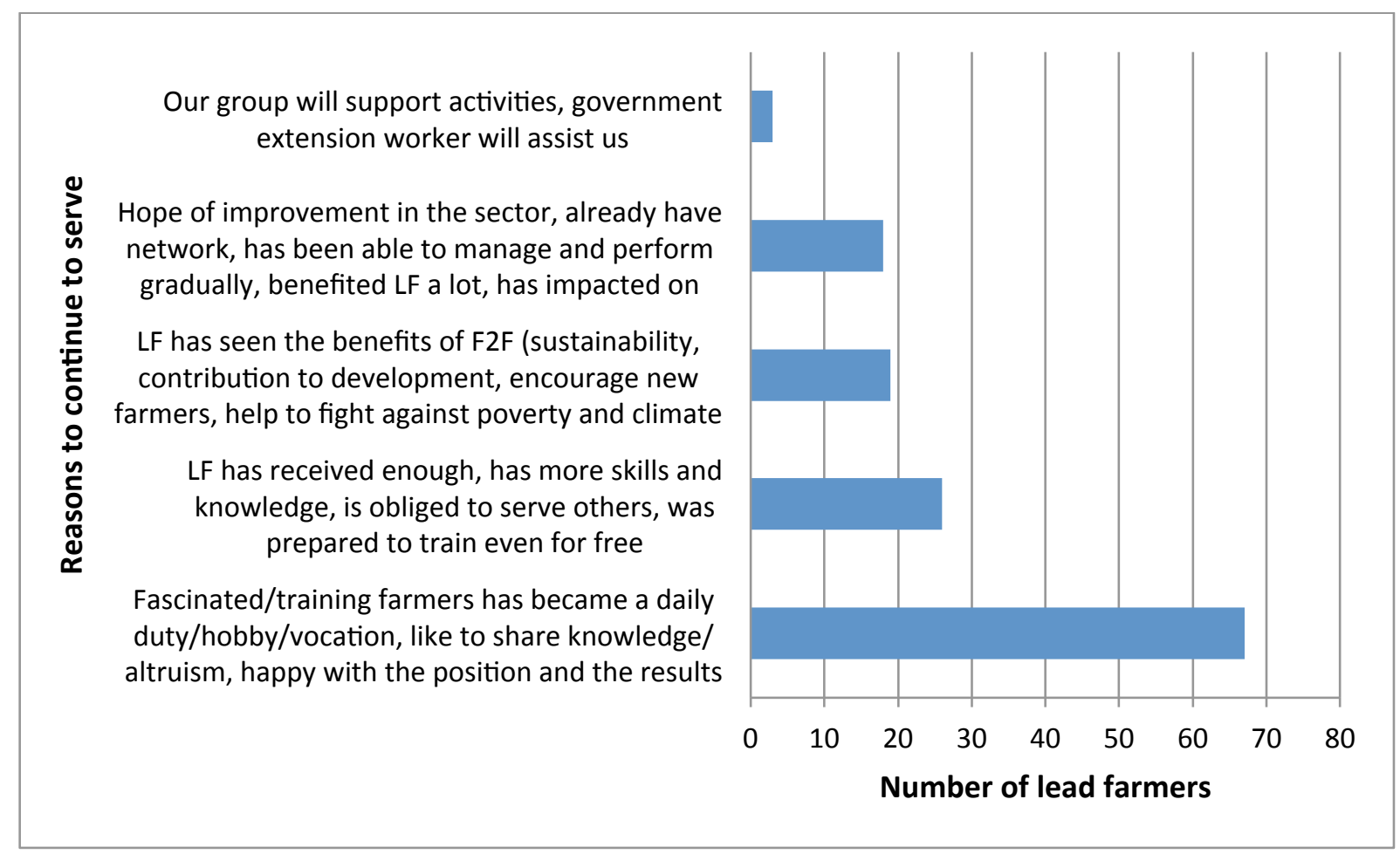

Figure 30. Reasons for lead farmers to continue to serve if organization leaves or projects end.

The most common reason given for continuing to work as a lead farmer if the initiatives they worked with ended, cited by 42 percent of LFs, was that they enjoy their training job so much that they now consider it a hobby. LFs are excited to help their peers and to share knowledge. Others said that LFs are obliged to train other farmers because they have more skills and knowledge, and that their groups and government extension workers will support them. Nine LFs declared, however, that they were tempted to stop serving as LFs because they found the workload to be too much without support. Apart from these reasons and age that could prevent LFs from continuing, some LFs also said they were discouraged by low participation of farmers in training sessions. Some LFs insisted that support organizations are needed to manage conflicts - for instance, between LFs, or between LFs and other stakeholders, such as farmers and extension workers. These LFs do not feel confident that they would continue serving as LFs when the organization leaves.

Lead farmers also noted skills that they needed to perform better. A significant proportion (43 percent) declared that they do not have sufficient knowledge and skills to perform well in their job. They identified a number of skills in which they desired additional training, such as sustainable development, leadership and communication (Figure 31). 


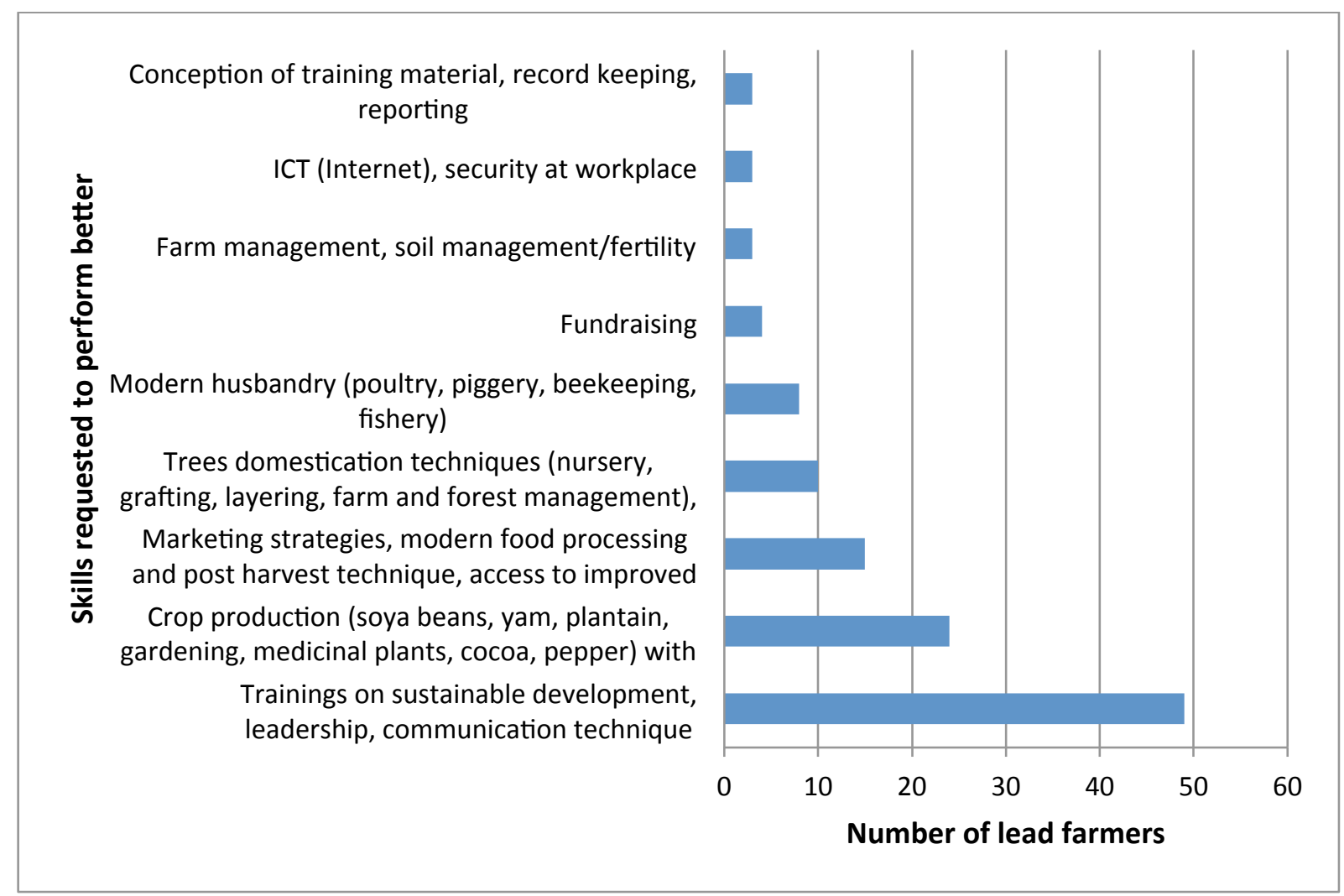

Figure 31. Skills that lead farmers need to perform better.

Fifty-seven percent of LFs identified the need to invest in the overall development of LFs' capacities. Some LFs liked the F2F approach because their role means they have been able to get to know more people and learn many things. In addition, 55 percent of LFs wished that government would promote the F2F extension approach vigorously. In rural areas, if farmers use good agricultural practices/innovations, they will not lack food or money and their household will not suffer from poverty. LFs also wished that the youth would be encouraged to become LFs to ensure the sustainability of the farmer-to-farmer approach. 


\section{DISCUSSION AND CONCLUSION}

\section{Who are lead farmers, what do they do and how are they supported?}

The results of this study show that nearly all LFs in Cameroon belong to farmers' groups. About half belong to two or three groups, and they primarily train members of those groups. In addition, the more groups that LFs belong to, the more groups they interact with through training and technical backstopping. The importance of group membership in the F2F extension approach was noted by Kiptot and Franzel (2014), who found that group members use trust, a main feature of social capital, as a means of ensuring that LFs meet their obligations. It is therefore not surprising that groups and communities are responsible for LF selection in the majority of cases, and that the criteria used to select LFs, include being hardworking, having good communication skills, being available, and showing interest and desire to help others. Though education level is generally not so important for LF selection, the study shows that slightly more than half of the LFs had levels above primary education, and a quarter even had tertiary education.

LFs undertook diverse activities in the communities where they worked: they trained other farmers, provided technical advice, monitored activities and mobilized communities to attend training events and demonstrations, among others. A third of the LFs met with their trainees weekly; two-thirds visited their trainees upon request. To be able to perform in their job, almost all LFs received initial training, mainly residential training of six to eight days. Across the LFs interviewed, this initial training focused mainly on technical aspects related to crop production (42 percent), general agricultural practices (27 percent) and agroforestry (26 percent). LFs were reasonably satisfied with the competencies they gained through this training, rating their performance on average at 3.77 on a scale from 1 to 5 . Just over half felt that the topics they were trained on were "well mastered". LFs' responses indicated that very little attention was given to issues such as climate change adaptation, natural resources management and entrepreneurship, nor was emphasis put on improving the communication and extension skills of the LFs. Subsequent training received on-the-job seemed to be more diverse and included topics related to income generation and leadership. Most LFs were supervised by staff members of extension organizations, and half of them received follow-up visits at least once a month. Slightly more than half of LFs collaborated with government extension workers, and the same number met with other LFs on a monthly basis. These interactions allowed LFs to enhance their knowledge and skills and improve their performance.

\section{What is motivating LFs? Costs and benefits}

Very few of the LFs interviewed received some kind of salary, so understanding what motivates LFs to become and to remain LFs is important. Findings by Kiptot and Franzel (2014) in Kenya suggest that volunteer farmer trainers are motivated by personal and community interests. Personal interests include improving oneself economically, building knowledge and skills, and enhancing social contacts. Community interests centred primarily around altruism, which also strengthens social ties. In Cameroon, we found that key 
motivations to become a LF were the prospect of income generation, followed by altruism and early access to new technologies. The same motivations played a role in decisions about remaining a LF, though altruism becomes more important than prospects for income generation. Indeed, many LFs feel more or less obliged to continue training others because they have received the knowledge and skills and are therefore in a privileged position compared with their fellow farmers. Expectations of the communities they serve may also be a factor in continuing in their roles. Developing social networks and increasing one's social status were also mentioned, but to a lesser extent. Almost all LFs said they had been able to earn more income from activities related to their function as LF - e.g., through increased yields because of the use of new techniques. One quarter also sold seeds and seedlings or produce from their demonstration plots, and some benefitted from free labour during trainings on their farms. LFs also indicated that their trainees gained economic benefits as well. Many LFs believed that farmers they trained are now able to earn more income from their farming activities.

The benefits do not come without costs, however. Over the 12 months prior to the interview, LFs spent on average 32,893 FCFA ( $\approx$ \$US66) in the execution of their function, primarily on transport and communication. More than two-thirds of the LFs reported financial limitations and insufficient transport and communication support as major challenges to the F2F extension approach. They also highlighted the often unrealistic expectations of farmers, especially for training and demonstration materials. Trainees also often ask for per-diems during training sessions; sometimes LFs felt obliged to provide food at the end of their training sessions.

\section{Gender}

One criticism of traditional extension methods is that they often fail to work with women farmers. Our findings showed that, in Cameroon, 30 percent of LFs were women. That proportion was almost equal to that of women field staff (28 percent) in organizations using the F2F approach in Cameroon (Tsafack et al., 2014). The motivations to become and remain a lead farmer were the same for women and men. The number of female and male LFs trained in the past year were not significantly different, but female LFs seem to work more with individual farmers than their male counterparts. When working with groups, they mostly associated with one group only; men LFs work with five groups on average. Female LFs trained more women proportionally than their male fellows ( 74 percent against 41 percent of trainees being women). Overall, 53.7 percent of trainees in the past year were female.

Female LFs also tend to train more farmers in their own houses/farms than men LFs, who train more in community halls and in the trainees' houses/farms. Only one woman used a motorbike, as compared to over one-quarter of the men, so women LFs are definitely limited in the area they can cover. Women LFs also used cellphones to communicate with field staff and trainees less than their male counterparts. 
Though there seem to be deliberate efforts by organizations' field staff and extension workers to select women as LFs, these organizations do not support women LFs as much as men. Field staff members visited women LFs less frequently than men LFs, and the proportion of women LFs who received training materials was lower than that of men LFs. On the other hand, female LFs appear to receive more recognition and awards, especially in their groups or communities.

\section{Sustainability}

Kiptot and Franzel (2014) in their study on LFs in Kenya concluded that voluntary farmers could work effectively without being paid for their services. According to our findings in Cameroon, 94 percent of LFs would continue being LFs even after projects end or support stops, the major reason being that they enjoy training others. They acknowledged that F2F extension holds advantages over other extension approaches. F2F is better in developing local capacities, facilitates and increases adoption of innovations, and allows for increased the number of farmers trained. When the extension message is delivered by LFs, it is more relevant because they are more flexible compared to government extension workers. In addition, LFs also better consider local realities.

Nevertheless, for the approach to be sustainable, LFs asked to be provided with financial and non-financial incentives, especially to cover transportation and communication costs. They also suggested that training more LFs and incorporating more youth should be encouraged, along with more training opportunities for LFs (on new topics and refresher courses) and study visits for existing LFs, so they keep abreast of recent developments. LFs said also that extension managers in government and non-governmental organizations should be made aware of the importance and complementarity of F2F extension so they can promote the approach more vigorously. 


\section{REFERENCES}

Bentley, J., Van Mele, P. and Musimami, G. 2013. The Mud on Their Legs - Farmer to Farmer Videos in Uganda. MEAS Case Study \# 3.

Braun, A. R. and Hocdé, H. 2000. "Farmer Participatory Research in Latin America: Four Cases”, in W.W. Stur, P.M. Horne, J.B. Hacker and P.C. Kerridge (eds.) Working with Farmers: The Key to Adoption of Forage Technologies. ACIAR Publication, PR095, pp. 32-53.

Degrande, A., SiohdjieYeptiep, Y., Franzel, S., Asaah, E., Takoutsing, B., Tsobeng, A. and Tchoundjeu, Z. 2014. Disseminating agroforestry innovations in Cameroon: Are relay organisations effective? In : Van Lauwe B., Van Asten P. and Blomme G. (Eds) Agroecological Intensification of Agricultural Systems in the African Highlands, Routledge, New York, USA. PP $221-230$

Gale, C., Collett, K. and Freccero, P. 2013. Delivering Extension Services through Effective and Inclusive Women's Groups: The Case of SEWA in India. MEAS Case Study \#5.

Hird-Younger, M., and Simpson, B. 2013. Women Extension Volunteers: An Extension Approach for Female Farmers. MEAS Case Study \# 2. Available at https://docs.google.com/viewer? $\mathrm{a}=\mathrm{v} \& \mathrm{pid}=$ sites\&srcid=bWVhcy1leHRlbnNpb24ub3JnfH B1YmxpY3xneDoxMjZiOGQ4NTliYTQ3MGZ1 (accessed August 2014).

Kiptot, E., Franzel, S., Hebinck, P., and Richards, P. 2006. Sharing seed and knowledge: Farmer to farmer dissemination of agroforestry technologies in western Kenya. Agroforestry Systems, 68:3:167-180.

Kiptot, E., Franzel, S. and Kirui, J. 2012. Volunteer farmer trainers: Improving smallholder farmers' access to information for a stronger dairy sector. Policy Brief No. 13, 2012, World Agroforestry Centre.

Kiptot, E. and Franzel, S. 2014. Voluntarism as an investment in human, social and financial capital: evidence from a farmer-to-farmer extension program in Kenya. Agriculture and Human Values: Journal of the Agriculture, Food, and Human Values Society. DOI 10.1007/s10460-013-9463-5

Lukuyu, B., Place, F., Franzel, S. and Kiptot, E. 2012. Disseminating Improved Practices: Are Volunteer Farmer Trainers Effective? The Journal of Agricultural Education and Extension, 18:5, 525-540. Available at http://dx.doi.org/10.1080/1389224X.2012.707066.

MINADER. 2009. Zones agro-écologiques. Chambre d'Agriculture de l'Ouest Cameroun, informations géographiques et économiques. Available at

http://chagriouestcamer.afrikblog.com/archives/2009/03/30/13194779.html. Accessed May 17, 2013.

Rakotomalala, Ricco. 2012. Analyse de corrélation : Étude des dépendances - Variables quantitatives. Version 1.0, Université Lumière Lyon. Available at http://eric.univlyon2.fr/ ricco/cours/cours/Analyse_de_Correlation.pdf. Accessed April 23, 2014. 
Tsafack, S., Degrande, A., Franzel, S. and Simpson, B. 2014. Farmer-to-farmer extension in Cameroon: a survey of extension organizations. ICRAF Working Paper No. 182. Nairobi, World Agroforestry Centre.

http://www.worldagroforestry.org/downloads/publications/PDFs/WP14383.PDF 


\section{WORKING PAPER SERIES}

2013

171. Stakeholder Preferences over Rewards for Ecosystem Services: Implications for a REDD+ Benefit Distribution System in Viet Nam

172. Payments for ecosystem services schemes: project-level insights on benefits for ecosystems and the rural poor

173. Good practices for smallholder teak plantations: keys to success

174. Market analysis of selected agroforestry products in the Vision for Change Project intervention Zone, Côte d'Ivoire

175. Rattan futures in Katingan: why do smallholders abandon or keep their gardens in Indonesia's 'rattan district'?

176. Management along a gradient: the case of Southeast Sulawesi's cacao production landscapes

2014

177. Are trees buffering ecosystems and livelihoods in agricultural landscapes of the Lower Mekong Basin? Consequences of climate-change adaptation. http://dx.doi.org/10.5716/WP14047.PDF

178. Agroforestry, livestock, fodder production and climate change adaptation and mitigation in East Africa: issues and options. http://dx.doi.org/10.5716/WP14050.PDF

179. Trees on farms: an update and reanalysis of agroforestry's global extent and socio-ecological characteristics. http://dx.doi.org/10.5716/WP14064.PDF

180. Beyond reforestation: an assessment of Vietnam's REDD+ readiness. http://dx.doi.org/10.5716/WP14097.PDF

181. Farmer-to-farmer extension in Kenya: the perspectives of organizations using the approach. http://dx.doi.org/10.5716/WP14380.PDF

182. Farmer-to-farmer extension in Cameroon: a survey of extension organizations. http://dx.doi.org/10.5716/WP14383.PDF

183. Farmer-to-farmer extension approach in Malawi: a survey of organizations: a survey of organizations http://dx.doi.org/10.5716/WP14391.PDF

184. Seri Agroforestri dan Kehutanan di Sulawesi: Kuantifikasi jasa lingkungan air dan karbon pola agroforestri pada hutan rakyat di wilayah sungai Jeneberang http://dx.doi.org/10.5716/WP14391.PDF

185. Options for Climate-Smart Agriculture at Kaptumo site in Kenya http://dx.doi.org/10.5716/WP14394.PDF

186. Agroforestry for landscape restoration and livelihood development in Central Asia http://dx.doi.org/10.5716/WP14143.PDF

187. Projected climate change and impact on bioclimatic conditions in the Central and South-Central Asia Region" http://dx.doi.org/10.5716/WP14144.PDF

188. Land cover changes, forest loss and degradation in Kutai Barat, Indonesia http://dx.doi.org/10.5716/WP14145.PDF

189. The farmer-to-farmer extension approach in Malawi: a survey of lead farmers. http://dx.doi.org/10.5716/WP14152.PDF

2015

190. Evaluating indicators of land degradation and targeting agroforestry interventions in smallholder farming systems in Ethiopia. http://dx.doi.org/10.5716/WP14252.PDF

191. Land health surveillance for identifying land constraints and targeting land management options in smallholder farming systems in Western Cameroon. http://dx.doi.org/10.5716/WP14253.PDF

192. Land health surveillance in four agroecologies in Malawi

193. Cocoa land health surveillance: an evidence-based approach to sustainable management of cocoa landscapes in the Nawa region, South-West Côte d'Ivoire

194. Situational analysis report: Xishuangbanna autonomous Dai Prefecture, Yunnan Province China. http://dx.doi.org/10.5716/WP14255.PDF 
The World Agroforestry Centre is an autonomous, non-profit research organization whose vision is a rural transformation in the developing world as smallholder households increase their use of trees in agricultural landscapes to improve food security, nutrition, income, health, shelter, social cohesion, energy resources and environmental sustainability. The Centre generates science-based knowledge about the diverse roles that trees play in agricultural landscapes, and uses its research to advance policies and practices, and their implementation that benefit the poor and the environment. It aims to ensure that all this is achieved by enhancing the quality of its science work, increasing operational efficiency, building and maintaining strong partnerships, accelerating the use and impact of its research, and promoting greater cohesion, interdependence and alignment within the organization.

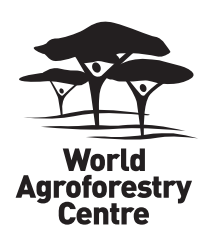

United Nations Avenue, Gigiri • PO Box 30677 • Nairobi, 00100 • Kenya Telephone: +254 207224000 or via USA +1 6508336645 Fax: +254207224001 or via USA +1 6508336646 Email: worldagroforestry@cgiar.org •www.worldagroforestry.org 